\title{
Paleocene Larger Foraminifera from the Pyrenean Basin with a recalibration of the Paleocene Shallow Benthic Zones
}

\section{Special volume: Biochronology of the South Pyrenean Cenozoic, in memoriam Josep Serra-Kiel}

\author{
$\begin{array}{llll}\text { J. Serra-Kiel }{ }^{1} \dagger & \text { V. Vicedo } & 2^{*} & \text { J.I. Baceta } \\ & \text { G. Bernaola } & \text { A. Robador } & \end{array}$
}

1Universitat de Barcelona, Facultat de Ciències de la Terra

Departament de Dinàmica de la Terra i de l'Oceà, Carrer de Martí Franquès s/n, 08028

Barcelona, Spain.

${ }^{2}$ Museu de Ciències Naturals de Barcelona, Departament de Paleontologia

Passeig Picasso s/n, 08003 Barcelona, Spain. E-mail: vvicedov@bcn.cat

${ }^{3}$ Department of Stratigraphy and Paleontology, University of the Basque Country (UPV/EHU) 48080 Bilbao, Spain. E-mail: juanignacio.baceta@ehu.eus

\begin{abstract}
${ }^{4}$ Deparment of Mining-Metallurgy Engineering and Material Science, Faculty of Engineering in Bilbao, University of the Basque Country (UPV/EHU)

Plaza Ingeniero Torres Quevedo 1, Bilbao, Spain. E-mail: gilen.bernaola@ehu.eus
\end{abstract}

Instituto Geológico y Minero de España

Ríos Rosas 23, 28003 Madrid, Spain. E-mail: a.robador@igme.es

\footnotetext{
* Corresponding author
}

\begin{abstract}
A taxonomic study of the Paleocene larger foraminifera from the Pyrenean basin has led to the description of sixty taxa including two new species: Alveolina korresensis and Valvulineria bacetai. In this work, we present a chronostratigraphic recalibration of the Paleocene Shallow Benthic Zones SBZ 1 to SBZ 4 based on correlation with calcareous nannofossil and planktic foraminifera biozones, all integrated within the stratigraphic framework of Paleocene platform to basin depositional sequences established for the whole Pyrenean domain. The samples were collected in autochtonous and parautochtonous deposits from ten key stratigraphic sections, representative of coastal to platform margin depositional settings. The results from two sections representing base of slope facies with intercalations of calcareous turbidites, which include penecontemporaneous platform-derived biota have been integrated in the study. The regional chronostratigraphic framework is derived from magneto-biochronological studies carried out in the Zumaia section, the global reference section for the Danian-Selandian and SelandianThanetian GSSPs. A new calibration of the Paleocene SBZs is proposed. The SBZ 1 is constrained to the first $1.09 \mathrm{~m}$.y. of the Paleocene; this first Paleogene biozone lacks distinct larger foraminiferal markers and thus is defined by an association of non-exclusive taxa composed of Valvulineria patalaensis, Stomatorbina? binkhorsti, Planorbulina? antiqua and Bangiana hanseni. The SBZ 2 now appears as the biozone encompassing most of the Danian stage (from ca. 64.9m.a. to 61.6m.a.), and is characterized by the association of Haymanella elongata, Haymanella paleocenica, Kayseriella decastroi, Rotospirella conica, Pyrenerotalia depressa, Elazigina
\end{abstract}

(C) J. Serra-Kiel, V. Vicedo, J.I. Baceta, G. Bernaola, A. Robador, 2020 CC BY-SA 
dienii, Ornatononion moorkensii and Paralockhartia eos. The SBZ 2-SBZ 3 boundary coincides with the base of the Selandian stage (ca. 61.6m.a.). The SBZ 3 biozone is defined by the occurrence of Glomalveolina primaeva, Periloculina slovenica, Vania anatolica, Coskinon rajkae, Fallotella alavensis, Cribrobulimina carniolica, Miscellanea yvettae, Miscellanea juliettae, Miscellanites primitivus, Miscellanites minutus, Ranikothalia soldadensis, "Operculina" heberti and Discocyclina seunesi. The SBZ 3-SBZ 4 boundary is now ascribed to ca. 57.2m.a. The SBZ 4 biozone appears characterized by Glomalveolina levis, Alveolina korresensis, Hottingerina lukasi, Daviesina garumnensis, Assilina yvettae, Assilina azilensis and Nummulites catari. The SBZ 4-SBZ 5 boundary is placed at the Paleocene-Eocene boundary event (ca. 56.0m.a.).

KEYWORDS $\quad$ Larger foraminifera. Biostratigraphy. SBZ. Pyrenean basin. Paleocene.

\section{INTRODUCTION}

The earliest systematic studies on larger foraminifera from the Paleocene of the Pyrenees are those by Mangin (1954, 1955, 1960, 1966), Hottinger (1960), Caus et al. (1980), Leppig (1988a, b) and Schaub (1981) in the SouthPyrenean domain and by Villatte $(1962,1969)$, Tambareau (1966, 1972) and Tambareau and Villatte $(1968,1974)$ in the North-Pyrenean realm.

The study of Paleocene larger foraminifera from the Pyrenean basin received a major boost with the development of the International Geological Correlation Programme (IGCP) Project 286 "Early Paleogene Benthos". This project organized two workshops in the Pyrenean basin. The first was hold in Jaca (Spain), in October 1990. At this meeting, several papers concerning stratigraphy, biostratigraphy and sequential analysis of Paleocene outcrops in the Southern Pyrenees were presented by Robador (1991), Serra-Kiel et al. (1991), Robador et al. (1991a, b). The second workshop was organized in Aspet (France), September 1994, with contributions concerning the stratigraphy and biostratigraphy of Paleocene successions by Tambareau et al. (1994a, b, c).

The first zonation of larger foraminifera of the Paleocene series was developed by Hottinger (1960) based on alveolinids. This biozonation included the $G$. primaeva Zone for the lower Thanetian and the $G$. levis Zone for the upper Thanetian. Later, Schaub (1981) characterized the Assilina yvettae Zone for the late Thanetian based on nummulitids. As one of the main conclusions of the IGCP Project 286 "Early Paleogene Benthos", the first integrated biostratigraphic zonation for Paleogene platform series, the Paleogene Shallow Benthic Zones (SBZ), was published by Serra-Kiel et al. (1998).

The PhD theses of Baceta (1996) and Robador (2005) contributed to the stratigraphic and sedimentologic knowledge of the Paleocene of the South Pyrenean realm. Both authors studied and correlated numerous stratigraphic sections from the continental-marine transitional environments to platform-slope and hemipelagic environments. In both theses, biostratigraphy was achieved through larger foraminifera in the carbonate platform environments, and planktonic foraminifera and calcareous nannoplankton in outer platform and hemipelagic environments. These correlations are reported in many studies such as Baceta et al. (2004, 2005, 2006a, b, 2011), Bernaola (2002, 2007), Bernaola and Nuño-Arana (2006), Bernaola et al. (2007, 2009), Orue-Etxebarria et al. (1996, 2001), Pujalte et al. (1994, 1998a, b, 2000a, b, 2002, 2009a, b, 2011, 2014, 2016) and Serra-Kiel et al. (1994).

These stratigraphic contributions were used by Baceta et al. (2004) to define the depositional sequences (DS) called Ma-Da, Da-1, Da-2, Se/Th-1 and Th-2, which encompass the entire Paleocene, and were later incorporated into various publications including a synthesis paper leading to the formal definition of the Global Stratotype Sections and Points for the bases of the Selandian and Thanetian stages (Schmitz et al. 2011).

The position of the Paleocene/Eocene boundary in shallow platform successions at the base of the Ilerdian stage has been of wide use in studies on larger foraminifera from the whole Tethyan domain over the last five decades. Several recent studies have demonstrated that the Carbon Isotopic Event (CIE) that globally marks the Paleocene-Eocene boundary accurately matches the base of the Ilerdian in the stratotype and parastratotype sections (Pujalte et al., 2003, 2009a, b; Schmitz and Pujalte, 2003)This points out that the Ilerdian is indeed an appropriate chronostratigraphic stage, at least at the scale of the Tethyan realm, useful to characterize the shallow platform successions deposited during the early Ypresian stage, as defined by the International Commission on Stratigraphy.

In this context, we present a new systematic study of Paleocene larger foraminifera with the description of two new species and a recalibration of the stratigraphic extent of several taxa. With this updated database, we propose a new recalibration of the SBZs from SBZ 1 to SBZ 4. 


\section{MATERIAL AND METHODS}

The study is based on the biostratigraphic analysis of twelve sections of the Paleocene studied across the southern Pyrenean domain, between Aragón and the Basque Country regions (Fig. 1). Ten sections (Serraduy, Campo, Tena, Garralda, Urrobi, Andia, Lizarraga, Urbassa Pass, Leortza and Korres) are representative of different settings across the shallow platform domain and, consequently, are mostly made of shallow-water carbonate deposits. The two remaining sections, Aixola-Ermua and Monte Urko, represent base of slope areas and contain hemipelagic deposits with intercalations of shallowderived resedimented deposits. All sections were logged and sampled during different surveys carried out between 1990 and 2010. For the analysis of shallow benthic larger foraminifera, a numer between fifty and hundred selected hand-sized rock pieces were collected from each section. Their study in the lab involved slabbing and selection of specific areas for thin section preparation. More than one thousand and five hundred individual thin sections of standard size were processed and analyzed from all sections, using petrographic microscope and binocular lens with attached digital camera from the University of Barcelona and the University of the Basque Country. Microscopic analyses involved detailed identification and description of the different taxa of benthic foraminifera, either preserved in axial, equatorial and oblique sections, largely based on digital images taken at different magnifications. With the aim of simplification, only those samples and corresponding thin sections with relevant content in larger foraminifera were considered from each individual section (see below). The thin sections studied and the associated series of digital images are housed in the collections of the Instituto Geológico y Minero de España, the Department of Stratigraphy and Paleontology, University of the Basque Country (UPV/EHU), the Department of Earth and Ocean Dynamics, University of Barcelona (UB) and the Department of Palaeontology, Museu de Ciències Naturals de Barcelona (see Appendix I). The Josep Serra collection
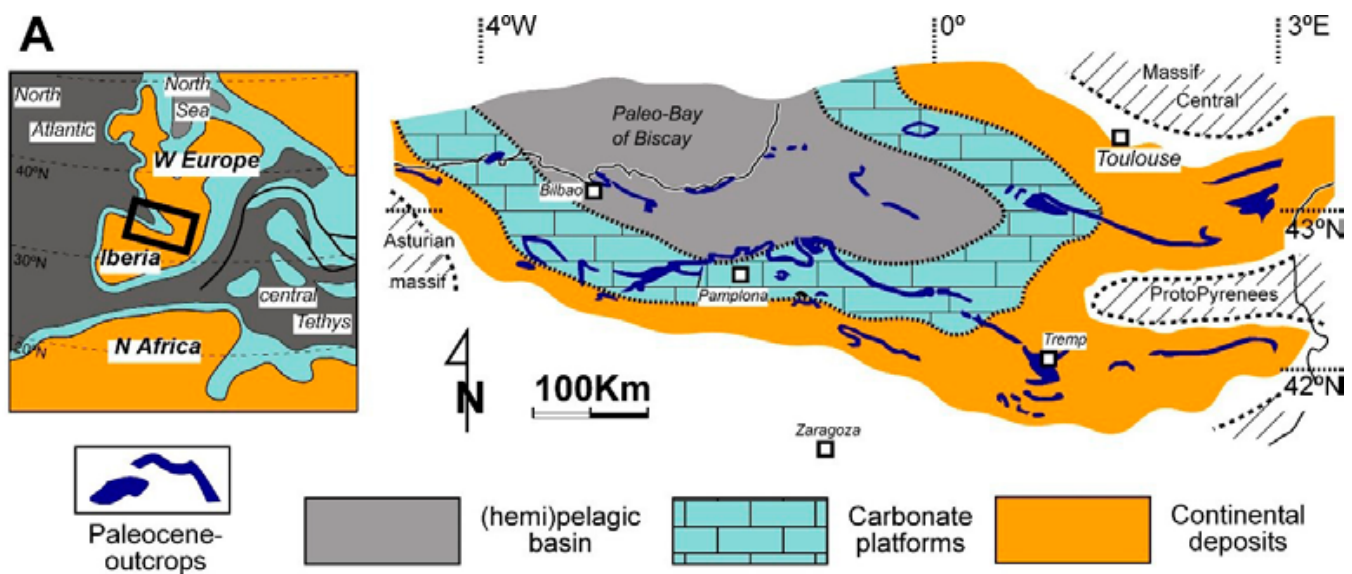

B
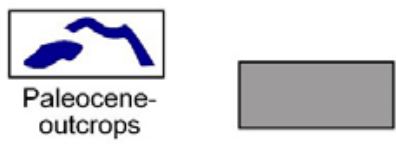

platforms

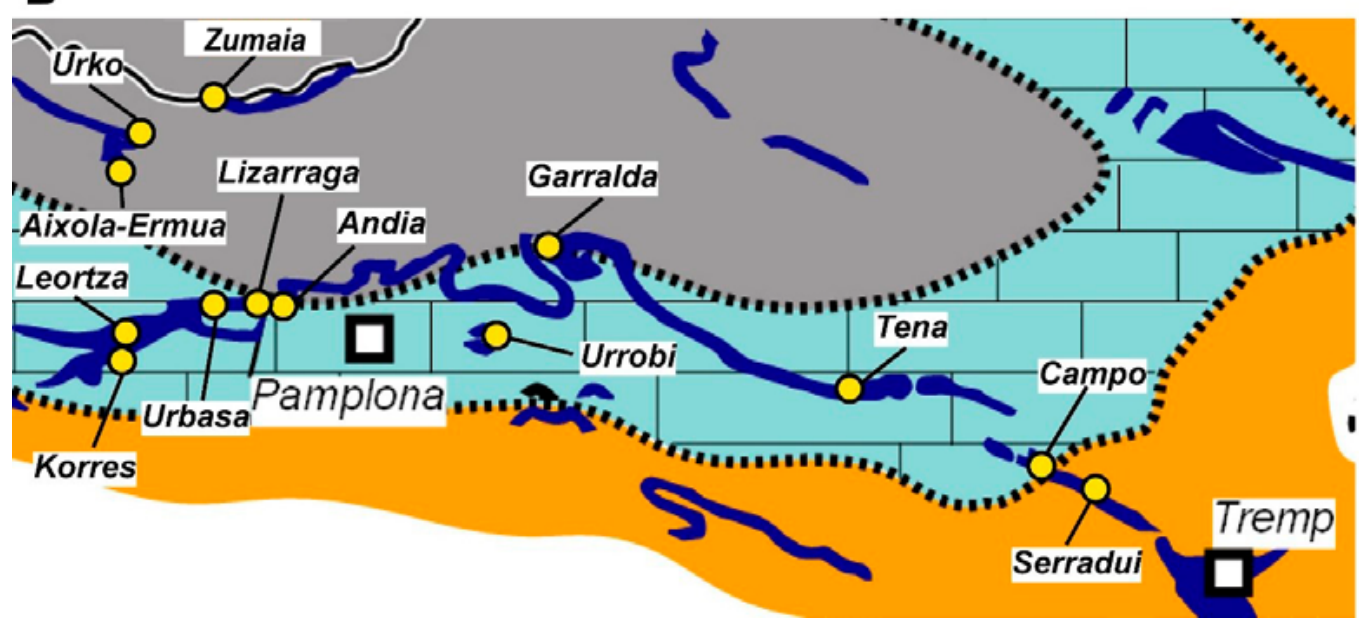

FIGURE 1. Geological setting of the study area. A) Location of the Pyrenean basin in a general paleogeographic map of Western Europe. B) Paleocene paleogeography and outcrop map of the Pyrenean basin. C) Location of the twelve reference sections for shallow benthic foraminifers studied. 
is now provisionally hosted in the Department of Earth and Ocean Dynamics, University of Barcelona (UB) but will possibly be transferred to the Museu de Ciències Naturals de Barcelona.

The study also involved detailed integration of all previous biostratigraphic data from calcareous nannofossil and planktic foraminifera from the sections of Lizarraga, Andia, Campo, Aixola-Ermua and Zumaia (Baceta, 1996; Baceta et al., 2005; Bernaola, 2002, 2007; Bernaola et al., 2006, 2007, 2009; Orue-Etxebarria et al., 2001; Pujalte et al., 1993, 1994) and new data of calcareous nannofossils from the Danian and Selandian of Aixola-Ermua and the Danian of Monte Urko sections. These new data involved the analysis of forty-six samples, seventeen from AixolaErmua section and twenty-nine from Monte Urko section. The standard Paleogene scheme of Martini (1971), with the amendments introduced by Perch-Nielsen (1981, 1985) regarding NP1/NP2 and NP2/NP3 zonal boundaries and the more recent biostratigraphic scheme proposed by Agnini et al. (2014) have been used for zonal identification. The combination of these two biozone schemes provides seventeen calcareous nannofossil zone boundary markers for the Paleocene and thus accurate age constraints for the stratigraphic succession to be established.

\section{Geological and stratigraphic settings}

In the Pyrenees, the Paleocene was a time of subdued tectonism, which developed under a semiarid to arid climate, globally rising sea levels and reduced siliciclastic supplies from the neighbouring emerged lands (Baceta, 1996; Baceta et al., 2004; Pujalte et al., 1993). The combined effect of these general conditions led to a transgression recorded across the whole Pyrenean embayment (Baceta, 1996; Baceta et al., 2004, 2006a, b, 2011; Pujalte et al., 2000a, b; Robador, 2008). The general paleogeography during this time consisted of a large sub-tropical marine embayment opening to the paleo-Bay of Biscay and the North Atlantic, with a 1000-1500m deep central basin surrounded on its north, south and east sides by shallow marine areas, in turn, flanked by broad continental alluvial plains (Baceta, 1996; Fig. 1A, B). The shallow marine areas were largely characterized by the deposition of skeletal and non-skeletal carbonate sediments, forming platform systems that in most sectors reached 30 to $40 \mathrm{~km}$ across dip and reached as much as $300-400 \mathrm{~m}$ in composite thickness. These carbonate platforms originally covered a total area of at least $40,000 \mathrm{~km}^{2}$.

The Paleocene platform successions from the Pyrenees consist mainly of shallow-water limestones deposited on beaches, tidal flats, lagoons, shoals and a variety of reef constructions, but also include minor proportions of siliciclastics and evaporites (Baceta et al., 2004, 2011).
Pene-contemporaneous dolomitization likely produced by evaporative processes was particularly important during the Danian and middle Thanetian, and karstification took place during the Selandian, which largely represents a period of relative sea level lowstand (Baceta et al., 2001, 2007), and during the Paleocene-Eocene boundary (Pujalte et al., 2011, 2014). Basinwards, shallow carbonate platforms pass sharply, through narrow slopes, to hemipelagic deposits, in the form of rhythmic alternations of limestone, marlstone and marl, locally with intercalations of thin calcareous, siliciclastic and mixed turbidites. In slope and base of slope settings, the basinal hemipelagites also intercalate numerous shallow-derived carbonate breccias and bioclastic turbidites (Baceta, 1996). These resedimented deposits usually occur in the form of gully systems and apron-like accumulations (Baceta, 1996; Baceta et al., 2004; Pujalte et al., 1993; Robador, 2005). Landwards, the carbonate platform succession interfingers with alluvial-lacustrine coastal plain sediments. These non-marine deposits, extensively developed in the south-central Pyrenees, are classically known in the literature as the "Garumnian" facies, Tremp Formation, or Tremp Group (Cuevas, 1992; Eichenseer, 1988; López-Martínez and Peláez-Campomanes, 1999; Rosell et al., 2001; Schmitz and Pujalte, 2003).

The long-term transgressive trend of the Paleocene carbonate platforms was punctuated by third-order oscillations in relative sea level. The stratigraphic signature of these sea-level changes is a suite of regionally extensive Depositional Sequences (DS), which form the building blocks of the platform-to-basin Paleocene succession (Fig. 2). The five DS recognized have been coded according to their estimated chronostratigraphic range. Their features fit reasonably well with current models established for landattached carbonate platforms sensu Wright and Burchette (1996), although their character and stacking pattern vary significantly depending on the carbonate sediment types involved, the presence of siliciclastic sediments and the platform depositional profile (ramp or rimmed shelf) in each time slice (Baceta et al., 2004, 2011). In general, Paleocene DS consist mostly of transgressive and highstand system tracts and contain poorly developed lowstand system tracts. Their boundaries correspond to discontinuity surfaces with numerous features of subaerial exposure, clear evidence of drops in sea level. The most prominent and longest lasting of these lowstands took place during the DanianSelandian boundary and caused the complete exposure of the Danian platform succession and the formation of a complex paleokarst system for a period of about $2.5 \mathrm{~m}$.y. (Baceta et al., 2001, 2007). The establishment and platform-to-basin correlation of the Paleocene DS solved many of the incongruences and misinterpretations in the numerous formal and informal lithostratigraphic units established within the Pyrenean Paleocene stratigraphic record (Garrido-Megías and Rios, 1972). 
Biostratigraphic studies contributed to basin-wide correlations and the detailed chronostratigraphic calibration of the Paleocene DS. These were accurately dated with planktic foraminifers and calcareous nannofossils, which abound in slope hemipelagites and some outer platform deposits. In addition, most platform deposits contain shallow benthic foraminifers, which occur in great quantity and can be easily recognized in the field. They are, therefore, the best option for dating Paleogene shallowwater platform deposits, particularly in isolated outcrops and sections. The correlation chart in Figure 2 summarizes the relationship between planktonic foraminifera and calcareous nannofossil zones, the Geomagnetic Polarity Time Scale (GPTS) and third-order DS of the Paleoceneearly Eocene of the Pyrenean basin. This correlation chart is primarily based on reference sections from the most

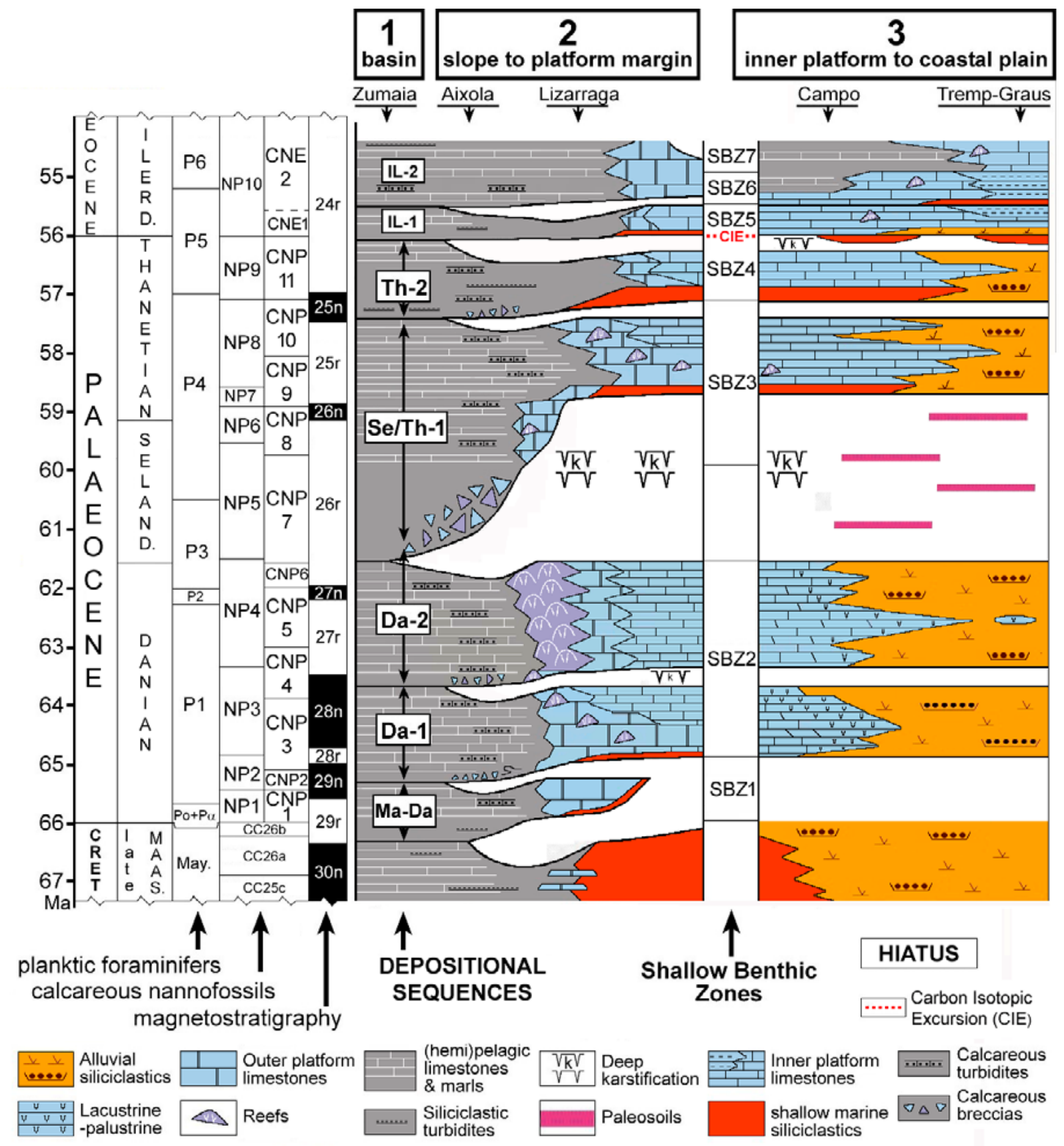

FIGURE 2. Bio-chronostratigraphic framework of the Pyrenean Paleocene-lower Ilerdian platform-to-basin succession, showing depositional sequences and main facies (modified from Baceta et al., 2004, 2011). The Geologic Time Scale used is in accordance with the 2017 International Chronostratigraphic Chart (Cohen et al., 2013) and Vandenberghe et al. (2012) and the Paleocene stage subdivision in accordance with Global Stratotype Section and Points (GSSPs) established in the Zumaia reference section (Schmitz et al., 2011). 
representative inner platform-to-coastal plain settings (Tremp, Campo), the platform margin (Lizarraga pass) and base of slope (Aixola-Ermua, Monte Urko), all correlated with the reference basinal section of Zumaia. This chronostratigraphic framework incorporates the recently adopted formal position of the Danian-Selandian, Selandian-Thanetian and Paleocene-Eocene boundaries (Schmitz et al., 2011).

\section{Description of the stratigraphic sections}

For this work, we have selected a series of stratigraphic sections that contain larger foraminifera ranging from transitional continental-marine realms, to inner platform, middle platform, the platform margin, the base of slope and hemipelagic environments. For the correlation among the different taxa of biostratigraphic use, special attention has been paid to stratigraphic sections with intercalations of deposits with calcareous plankton of biostratigraphic significance and to sections of platform slope and hemipelagic environments with calciturbidites that contain larger foraminifera that can be considered penecontemporaneous to planktonic foraminifera and calcareous nannoplankton.

The profiles selected run east-northwest across the Paleocene basin axis (Fig. 1C) and permit precise correlation of the larger foraminiferal zones (SBZ) with those of the calcareous nannoplankton (NP, CNP) and planktonic foraminifera $(\mathrm{P})$.

The description of the studied sections presented below takes as reference the Paleocene stratigraphic units defined in Figure 2. In all stratigraphic sections, the lithology is represented according to the legend set out in Figure 3.

\section{Serraduy section}

Serraduy section (Fig. 4) was measured on the west and east banks of the Isabena River and adjacent hillslopes, all located some $500-800 \mathrm{~m}$ to the north of the village of Serraduy.

UTM coordinates (ETRS89, H31) are X: 299.759, Y: 4.688.981 (bottom) and X: 300.261, Y: 4.688 .350 (top).

The base of the section is marine sandy limestone of the Arén Formation (Fm.) (Mey et al., 1968), Maastrichtian in age. The non-marine deposits encompassing the first interval described (Ma-Da to IL-1 depositional sequences) were referred as Garumnian facies by Leymerie (1868). Later Garrido-Megías and Ríos (1972) detailed the stratigraphy of this part of the section separating the continental deposits (their Laspún Fm.) from the marine

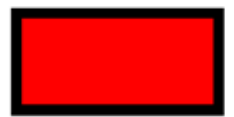

Red clay and silt

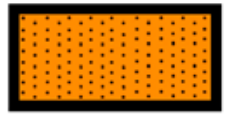
Sandstone

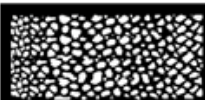

Honeycomblike dolomite

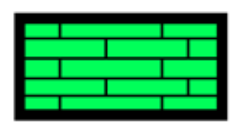

Limestone

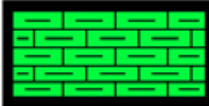

Marly limestone

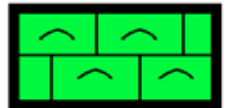

Coral-Algal boundstone

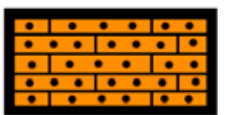

Calcarenites

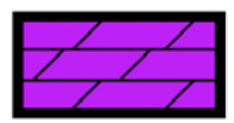

Dolomite

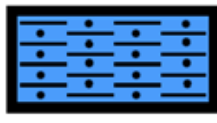

Sandy marlstone

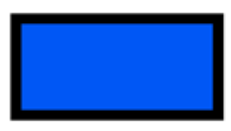

Grey silt

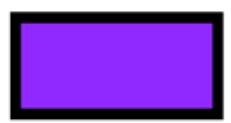

Calcareous turbidites

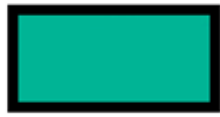

Calcareous breccia
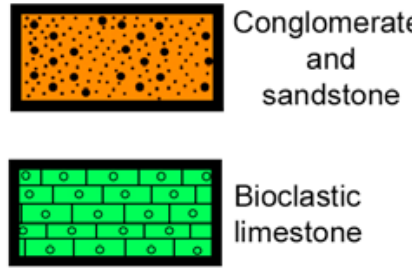

Bioclastic limestone

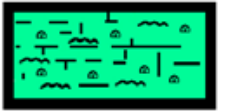

Massive coral limestone

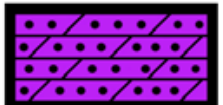

Sandy dolomite

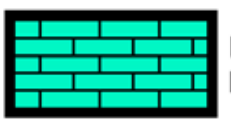

Lacustrine limestone

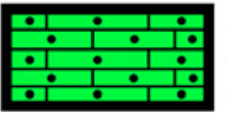

Sandy conglomeratic limestone

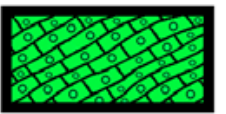

Cross beddes limestone

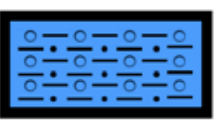

Bioclastic sandy silt

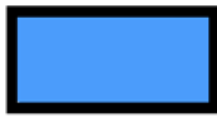

Marlstone

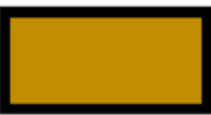

Siliciclastic turbidites

FIGURE 3. Lithological legend for Figures 5-13. 
intercalations found in the following depositional sequences (Se/Th-1 and Th-2 DS), which build up the Navarri Fm. Finally, the summit deposits (IL-1 depositional sequence), are included in the Serraduy Fm. (Cuevas-Gozalo et al., 1985). The stratigraphic succession can be divided into the following DS:

Ma-Da and Da-1 DS. The boundary between these two DS is difficult to determine. They constitute the lower half of the section, represented by $100 \mathrm{~m}$ of non-marine red clays with sandstone and silt intercalations including pedogenetic horizons.

Da-2 DS. It is represented by lacustrine limestone capped by two well-developed pedogenetic horizons corresponding to the Colmenar-Tremp horizon (Eichenseer, 1988).

Se/Th-1 DS. The basal limit of this sequence is the top of the pedogenetic horizon of the previous DS. This unit is made up of continental red and variegated clays and includes a marine intercalation in its upper part. This level is composed of a conglomeratic layer sandwiched between two shallow marine limestone beds with foraminifera. The uppermost part of the unit is again composed of red clays with nodular calcareous concretions. The occurrence of $I$. sinjarica, $G$. primaeva, $K$. aquitanica and $C$. carniolica in this stratigraphic interval characterizes SBZ 3.

Th-2 DS. This depositional sequence starts with a $1 \mathrm{~m}$-thick sandy conglomeratic bed, followed by $10 \mathrm{~m}$ of sandy limestone with abundant marine fossils, including oysters, corals and abundant larger foraminifera, followed by sandstone. The upper part of this DS consists of greenish-red bioturbated continental clays. The occurrence of D. garumnensis and G. levis in this DS is characteristic of SBZ 4.

The lower undifferentiated red clay unit (DS Ma-Da and Da-1) and the depositional sequences Da-2, Se/Th-1 and Th-2 have been referred to as the Laspún Fm. by GarridoMegías and Ríos (1972).

IL-1 DS. The bottom of this unit is formed by an incised channel with a conglomeratic infill overlain by a $6 \mathrm{~m}$-thick layer of calcareous sandstone and red clays. The remaining of the sequence is composed of two limestone intervals separated by a unit built up of unconsolidated rock, generally covered, consisting of marlstone and calcareous sandstone with plant remains, which indicate regressive conditions. The first of these two calcareous beds is a bioclastic, shallow marine limestone with very abundant Alveolina, that has been interpreted as as a giant sandwave. The occurrence in this DS of $A$. vredenburgi vredenburgi and A. globula indicates SBZ 5 in the lower part of IL-1, whereas in its upper part $A$. vredenburgi tumida and $A$. ellipsoidalis are indicative of SBZ 6. These deposits are included in the Serraduy Fm. (Cuevas-Gozalo et al., 1985).

\section{Campo section}

Campo section (Fig. 5) is located in the Ésera river gorge, south of the town of Campo. The section begins at $\mathrm{km} 4$ along the $\mathrm{N}-260$ road, following the path of the ancient, abandoned road, and crossing the Ésera Bridge towards the town of Ainsa.

UTM coordinates (ETRS89, H31) are X: 285.738, Y: 4.696.911 (bottom) and X: 285.660, Y: 4.696.180 (top). This section exposes a relatively thick succession of Paleocene to lower Ilerdian platform carbonates, arranged in up to six depositional sequences (Fig. 5). The underlying Maastrichtian deposits are sandy limestones pertaining to the Arén Fm. The depositional sequences Ma-Da, Da-1 and Da-2 belong to the Laspún Fm. (Garrido-Megías and Ríos, 1972), whereas Se/Th-1 and Th-2 deposits build up the Navarri Fm. (Garrido-Megías and Ríos, 1972). The continental deposits from the top of the Arén Fm. to the base of the Se/Th-1 sequence were characterized as Garumnian facies by Leymerie (1868). Ma-Da DS. This is a heterolithic unit composed of sandstones and marls in its lower part, a sandstone unit with rudist debris in the middle part, and an upper part build up of dolomicrite and red clays.

Da-1 DS. It is made up of secondary dolomites with calcareous algae and microfossil ghosts.

Da-2 DS. It is formed by white dolomicrites in its lower part, capped by some beds of oolitic limestones of lacustrine facies. The upper part begins with a collapse breccia composed of honeycomb-like dolomite followed by red and variegated clays and lacustrine limestone. Its upper limit is marked by a widespread paleosol catena, called the Colmenar-Tremp Horizon (Eichenseer, 1988). Se/Th-1 DS. The basal levels are composed of red-grey claystones and dolomites. The main body of this unit is composed of bioclastic, very fossiliferous limestones, deposited in lagoon/inner shelf environments. The regressive upper part of the section includes dolomites accumulated in supratidal marsh environments including an intercalation of continental clays with vertebrate remains (Tambareau et al., 1992a). The larger foraminifera $G$. primaeva, $V$. anatolica, $C$. rajkae, $C$. carniolica, $K$. aquitanica, $D$. praegarumnensis, $M$. yvettae, $M$. primitivus and $C$. ovoidea characterize SBZ 3.

Th-2 Ds. This is a transgressive unit composed mainly of very fossiliferous bioclastic limestones. Its central part has been interpreted as the deepest facies association of 


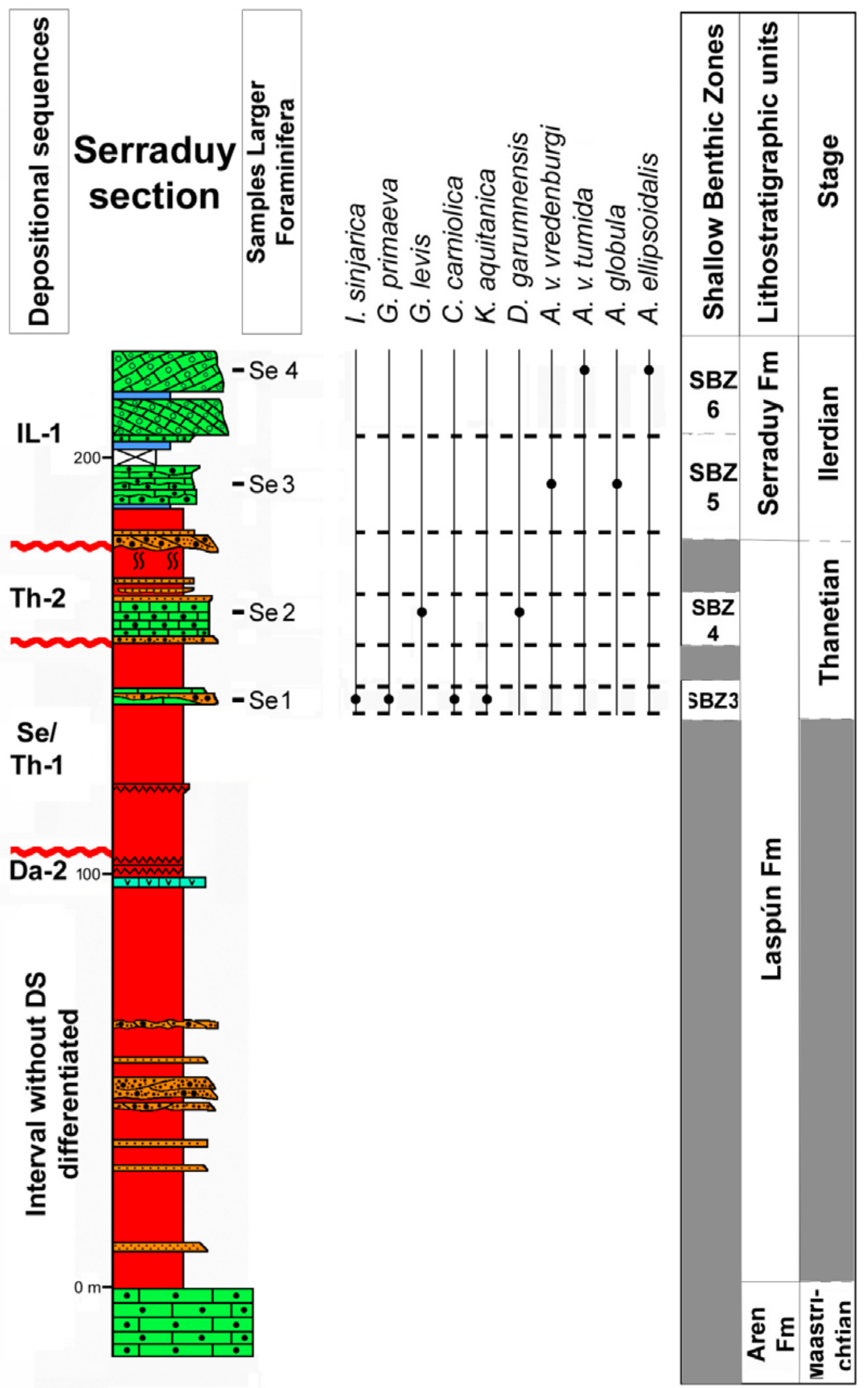

FIGURE 4. Stratigraphic succession and distribution of larger foraminifera in the Serraduy section. 
the entire Paleocene interval, and is represented by marls and marly limestones with autochthonous assemblages of calcareous nannofossils (Orue-Etxebarria et al. 2001). The middle and upper parts of this sequence is characterized by sandy, bioclastic and cross-bedded bioclastic limestones. In the uppermost part of the sequence, there are reefal boundstones. The top of this DS is a 5m-thick layer of mudstones with exhibits pedogenetic alteration and abundant Microcodium, indicating subaerial exposition. The presence in this unit of $G$. levis, D. garumnensis, $A$. yvettae and $A$. azilensis characterizes SBZ 4. The calcareous nannofossil assemblages recorded in the nine

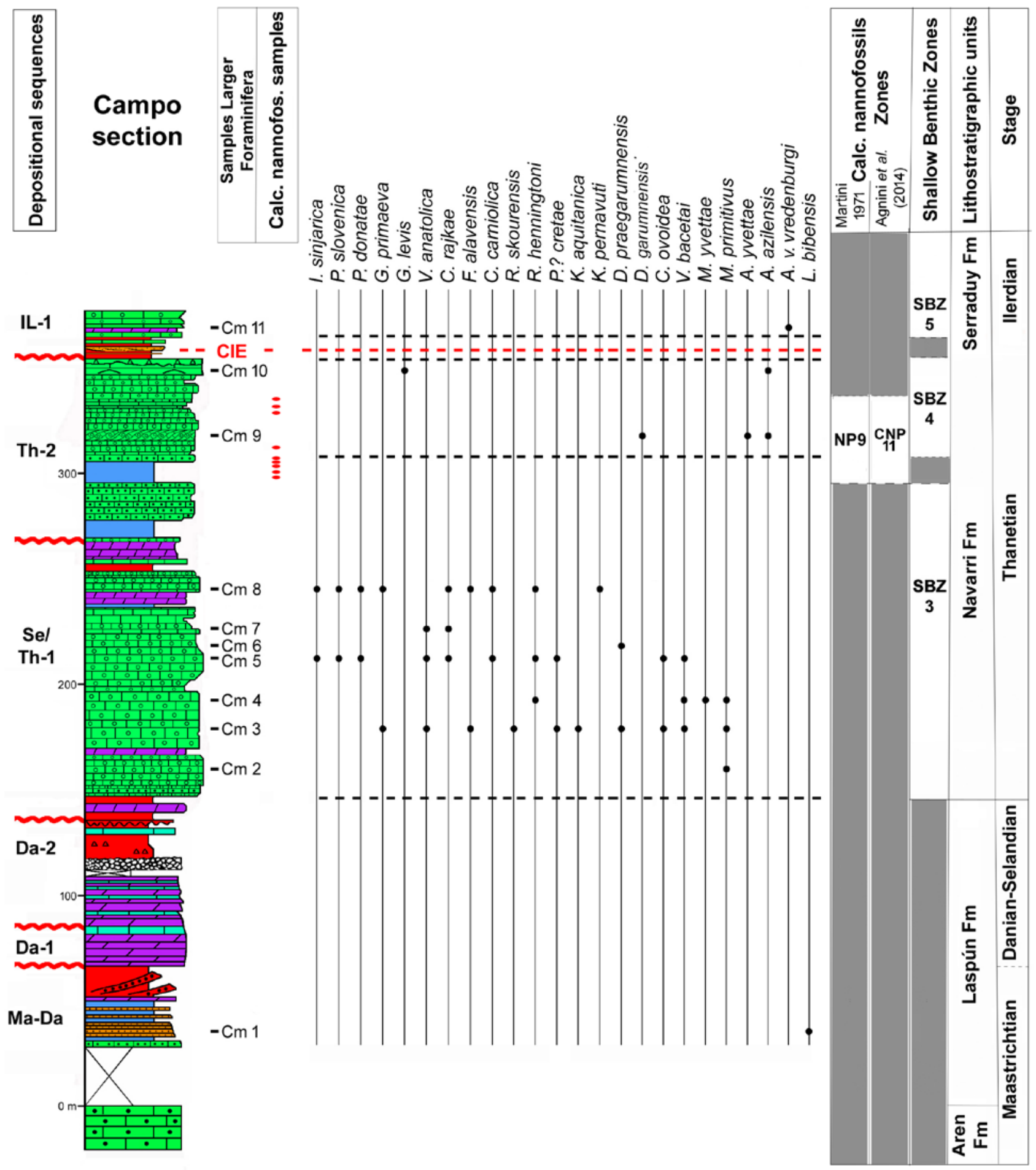

FIGURE 5. Stratigraphic succession and distribution of larger foraminifera in the Campo section. 
samples collected in the upper part of Th- 2 are indicative of Zone NP9 of Martini (1971) or Zone CNP11 of Agnini et al. (2014).

IL-1 DS. Thi unit begins with continental clays and sandstones, where the geochemical signal of the CIE of the Paleocene-Eocene thermal maximum has been located (Pujalte et al., 2009b; Schmitz and Pujalte, 2003). The upper part of the unit is made up of bioclastic limestone with Alveolina including A.v. vredenburgi, which characterizes SBZ 5.

\section{Tena section}

Tena section (Fig. 6) is located in the Gállego river gorge at the entrance of the Tena valley, north of the town of Biescas along the A-136 road in the vicinity of the kilometer point 4 and along the access path to the fort and hermitage of Santa Elena.

UTM coordinates (ETRS89, H30) are X: 719.322, Y: 4.726.687 (bottom) and X: 719.439, Y: 4.726 .505 (top).

The rocks underlying the Paleocene succession belong to the Marboré Fm. (Souquet, 1967) ands are mostly composed of sandstone and marlstone. Both Da-1 and Da-2 depositional sequences are referred to in the literature as the Salarons Fm. (Van de Velde, 1967). The depositional sequences Se/Th-1, Th-2 and IL-1 belong to the Gallinera Fm. (Van de Velde, 1967).

Da-1 DS. This unit is composed of dolomites and shallow marine limestones capped with intraformational breccia at top. The occurrence of $B$. hanseni at top is characteristic of SBZ 1.

Da-2 DS. This unit is characterized by shallow marine limestone with algal laminations, dolomites and shallow marine limestones at the top. Unfortunately, the absence of the larger foraminifera does not alow for a determination of the biostratigraphic range of this DS.

Se/Th-1 DS. The basal levels of this depositional sequence are characterized by sandstone and shallow sandy limestone, followed by algal boundstones and topped by shallow marine limestones. The occurrence of $G$. primaeva, $V$. anatolica, $F$. alavensis, $C$. carniolica, " $O$ ". heberti and D. seunesi characterizes SBZ 3.

Th-2 S. This unit is composed of very fossiliferous shallow marine sandy limestones. The occurrence of $G$. levis, A. yvettae and A. azilensis characterizes SBZ 4.

IL-1 DS. The bottom of this unit is represented by bioclastic sandy silt with abundant nummulitids followed by bioclastic limestone rich in alveolinids. The occurrence $N$. aff. minervensis and A.v. vredenburgi characterizes SBZ 5.

\section{Garralda section}

Garralda section (Fig. 7) was measured along a path that leaves the village of Garralda towards the north. It begins at the base of an abandoned limestone quarry and continues northward after a small water reservoir.

UTM coordinates (ETRS89, H30) are X: 639.894, Y: 4. 756.777 (bottom) and X: 639.879, Y: 4. 756.928 (top).

The rocks underlying the Paleocene succession are marly limestones belonging to the "Calcischistes à Navarelles" (Souquet, 1967) of Maastrichtian age. The DS Da-2 constitutes the Abaurrea Fm., while the DS Se/Th-1 and Th-2 and IL-1 belong to the Berrendi Fm. (Robador, 2008).

Da-2 DS. This unit is represented at its lowest part by a 1.5m-thick breccia composed of clasts made of limestone and marly clay chips. Above, the succession is composed of a 40m-thick, monotonous succession up of coarsening upwards bioclastic limestones with calcareous algae (rhodophyte) bioclasts. The occurrence in this unit of $M$. globularis, $O$. moorkensii and $E$. dienii is characteristic of SBZ 2.

Se/Th-1 DS. This unit is composed in its lower part by sandy, fine grained limestones, which overlies Da-2 deposits with a sharp, erosive contact. The upper half of the sequence is made of bioclastic limestones, where $V$. anatolica, $K$. aquitanica and $M$. yvettae where found and indicate SBZ 3.

Th-2 DS. This unit is composed in its basal levels by sandy limestones which abruptly overlie the bioclastic limestones of the previous sequence followed by bioclastic limestones with calcareous algae and corals.

IL-1 DS. This DS is made of alternating marls and marly limestones with abundant planktonic foraminifera. Due to their incompetent nature, their outcrops are very scarce, with its lower boundary being usually covered.

\section{Urrobi section}

Urrobi section (Fig. 8) was measured in year 1994 on the left bank of the Urrobi river south of the village of Nagore; however, it is no longer accessible as the area has been flooded by the Itoiz reservoir.

UTM coordinates (ETRS89, H30) are X: 633.448; Y: 4.743.460 (bottom) and X: 633.487; Y: 4.743 .057 (top). 
The rocks underlying the Paleocene succession belong to the Marboré Fm. represented by sandstones and marlstones. Both Da-1 and Da-2 depositional sequences belong to the Salarons Fm., while the DS Se/Th-1, Th-2 and IL-1 DS belong to the Gallinera Fm.

Da-1 DS. This unit is composed of shallow-marine dolomites with occasional interbedding of limestones. The presence of $B$. hanseni indicates SBZ 1 in the upper part of this unit.
Da-2 DS. This unit is represented by primary dolomites in its lower part and shallow marine limestones including bioclastic beds in the upper half. Unfortunately, the absence of larger foraminifera in this stratigraphic interval does not allow determining its biostratigraphic range.

Se/Th-1 DS. The basal levels are characterized by shallow marine sandy limestones, followed by alternating marlstones and sandy limestones. The top of the sequence is formed by boundstone and bioclastic marine limestone.
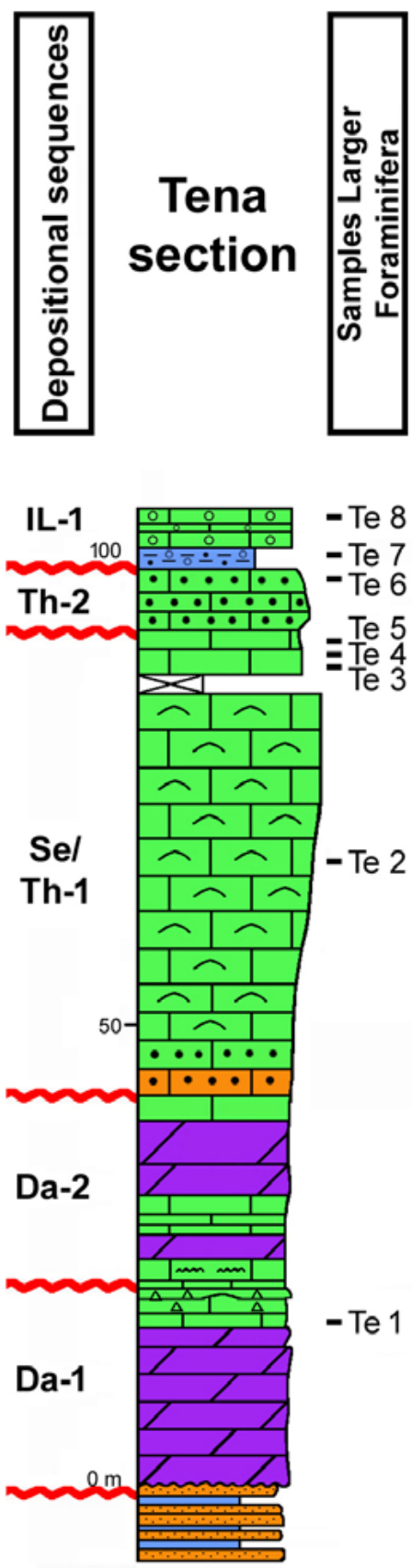

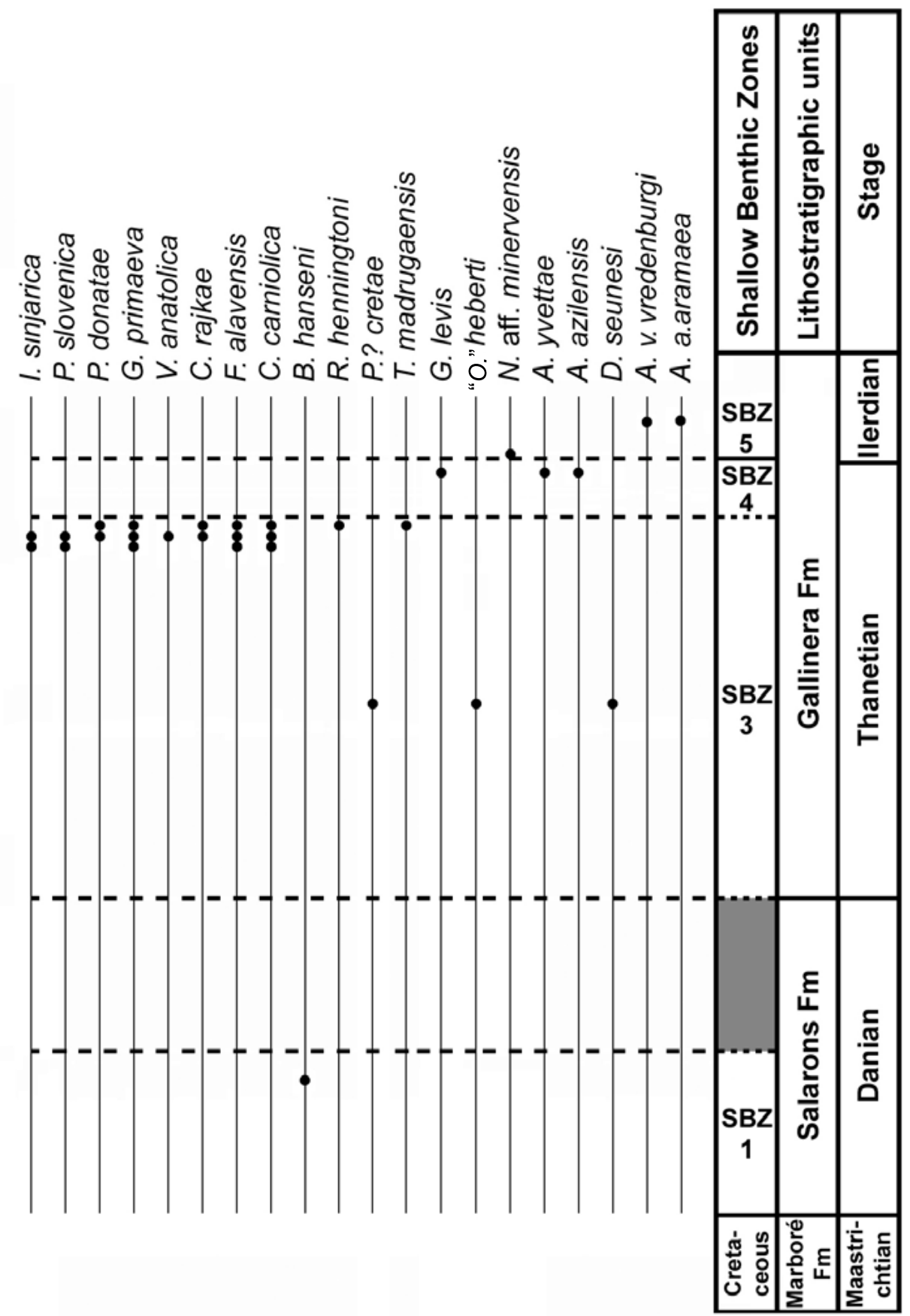

FIGURE 6. Stratigraphic succession and distribution of larger foraminifera in the Tena section. 

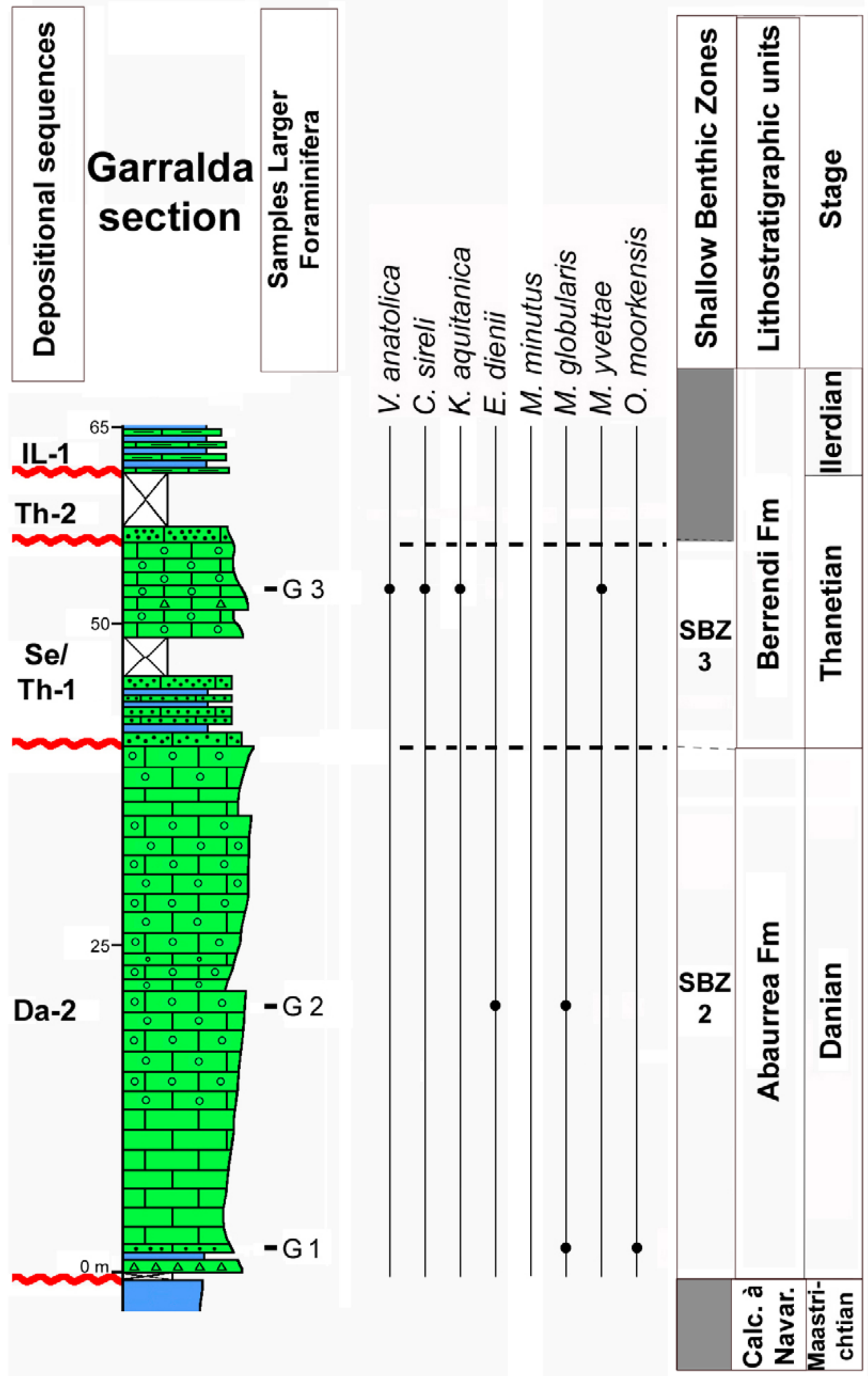

FIGURE 7. Stratigraphic succession and distribution of larger foraminifera in the Garralda section. 
The occurrence of " $O$ ". heberti and $D$. seunesi indicates SBZ 3.

Th-2 DS. This unit is composed of marlstone and very fossiliferous sandy limestones. The presence of $A$. yvettae and $A$. azilensis indicates SBZ 4.

IL-1 DS. The bottom of this sequence is formed by bioclastic sandy silt with abundant nummulitids where the geochemical signal of the CIE is located according to Pujalte et al. (2003). These rocks are followed by a bioclastic limestone rich in nummulitids, with $N$. aff. minervensis indicating SBZ 5.

\section{Andia section}

Andia section (Fig. 9) was logged on the edge of the plateau located approximately $1.5 \mathrm{~km}$ to the east of the Lizarraga mountain pass. It is provided here as subsidiary section of the Lizarraga section, described below. This
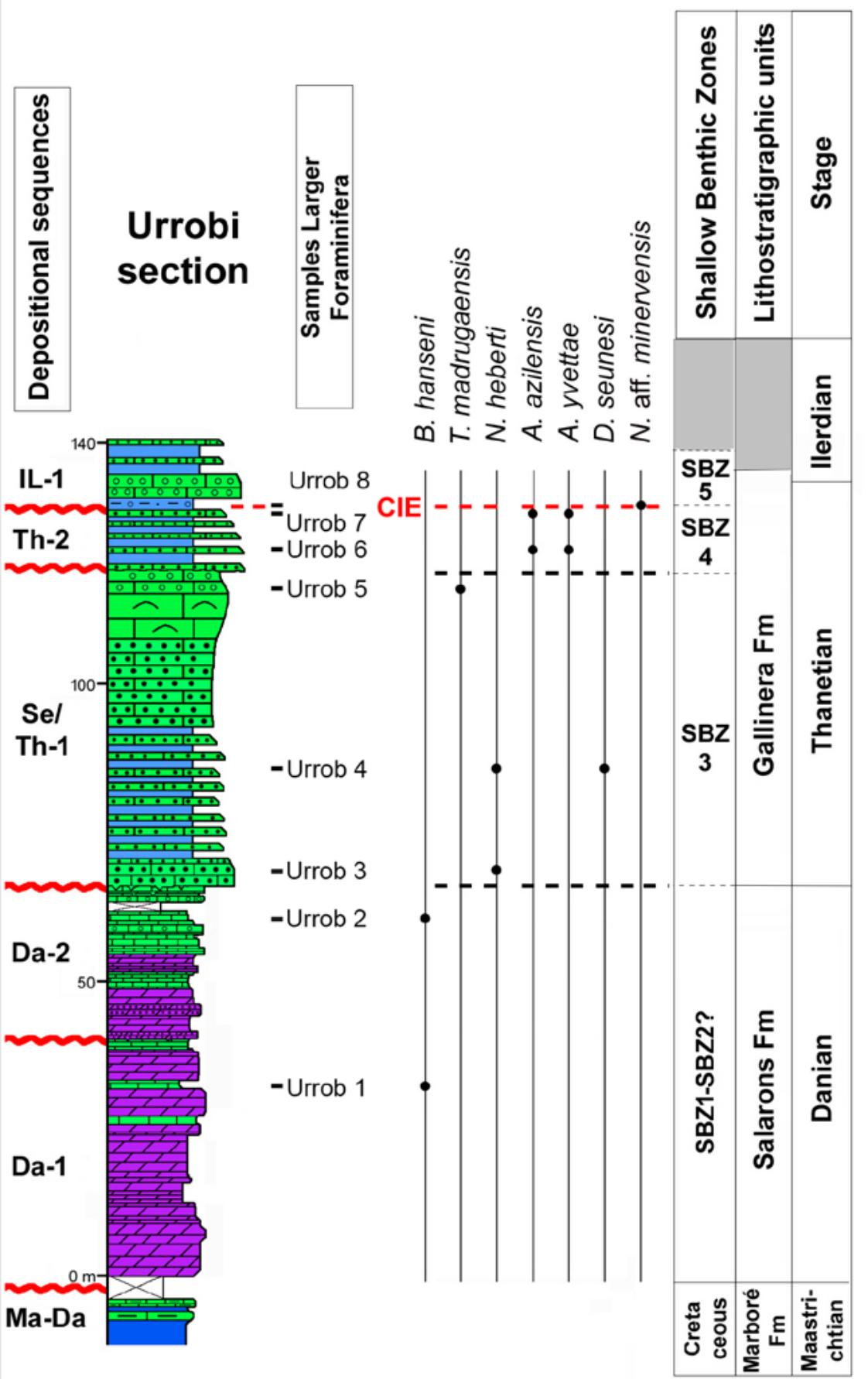

FIGURE 8. Stratigraphic succession and distribution of larger foraminifera in the Urrobi section. 
section is relevant in the Western Pyrenees as it is the only including Selandian deposits in shallow water facies, most of them relatively rich in larger foraminifera.

UTM coordinates (ETRS89, H30) are X: 582.279, Y: 4.746.093 (bottom) and X: 581.933, Y: 4.745 .805 (top).

\section{Se/Th-1 DS}

This sequence lies unconformably on upper Danian "Lizarraga reef complex" and is overlain by unnamed Ilerdian deposits. The succession is made up of marlstones and marly limestones interbedded with several $\mathrm{m}$-thick intervals of bioclastic limestones and very locally coralgal boundstones (Baceta et al., 2005). The stratigraphic interval logged is laterally equivalent to the informal unit known as Usabide reef complex (Baceta et al., 2005). The bioclastic limestones comprise a varied association of foraminifera indicative of the SBZ 3 biozone, namely, $G$. primaeva, $V$. anatolica, $C$. rajkae, $M$. primitivus, " $O$ ". heberti and $D$. seunesi. According to G. Bernaola in Baceta et al. (2005), the logged section encompasses the NP5, NP6, NP7 and NP8 calcareous nannofossil zones of Martini (1971). The revision of these data allowed us to recognize in the same interval the CNP7, CNP8, CNP9 and CNP10 calcareous nannofossil zones of Agnini et al. (2014).

\section{Lizarraga section}

Lizarraga section (Fig. 10) is located along the NA120 road from Etxarri-Aranatz to Estella/Lizarra across Lizarraga mountain pass, on the northern edge of the Urbasa-Andia synclinorium.

UTM coordinates (ETRS89, H30) are X: 581.722, Y: 4.746.147 (bottom) and X: 581.029, Y: 4.745 .731 (top).

The section consists of an up to $360 \mathrm{~m}$-thick Paleocene to Early Eocene platform margin succession including different intervals with calcareous nannofossils allowing for an accurate age determination. The Paleocene overlies conformably the Maastrichtian deposits (Puerto de Olazagutia Fm., Amiot, 1982). The Da-2 DS is informally known as the Lizarraga reef complex, while the Se-Th-1 DS is laterally equivalent to the so-called Legumbe reef complex and DS Th-2 to the so-called "Assilina beds". (Baceta et al., 2005).

Ma-Da DS. This unit is composed of marly limestones and fine-grained limestones lacking shallow benthic foraminifera. The top is characterized by an irregular bed of breccia interpreted as a slump. The NP1 or CNP1 (basal Danian) age of this unit was established in by Baceta et al. (2005) based on calcareous nannofossils.

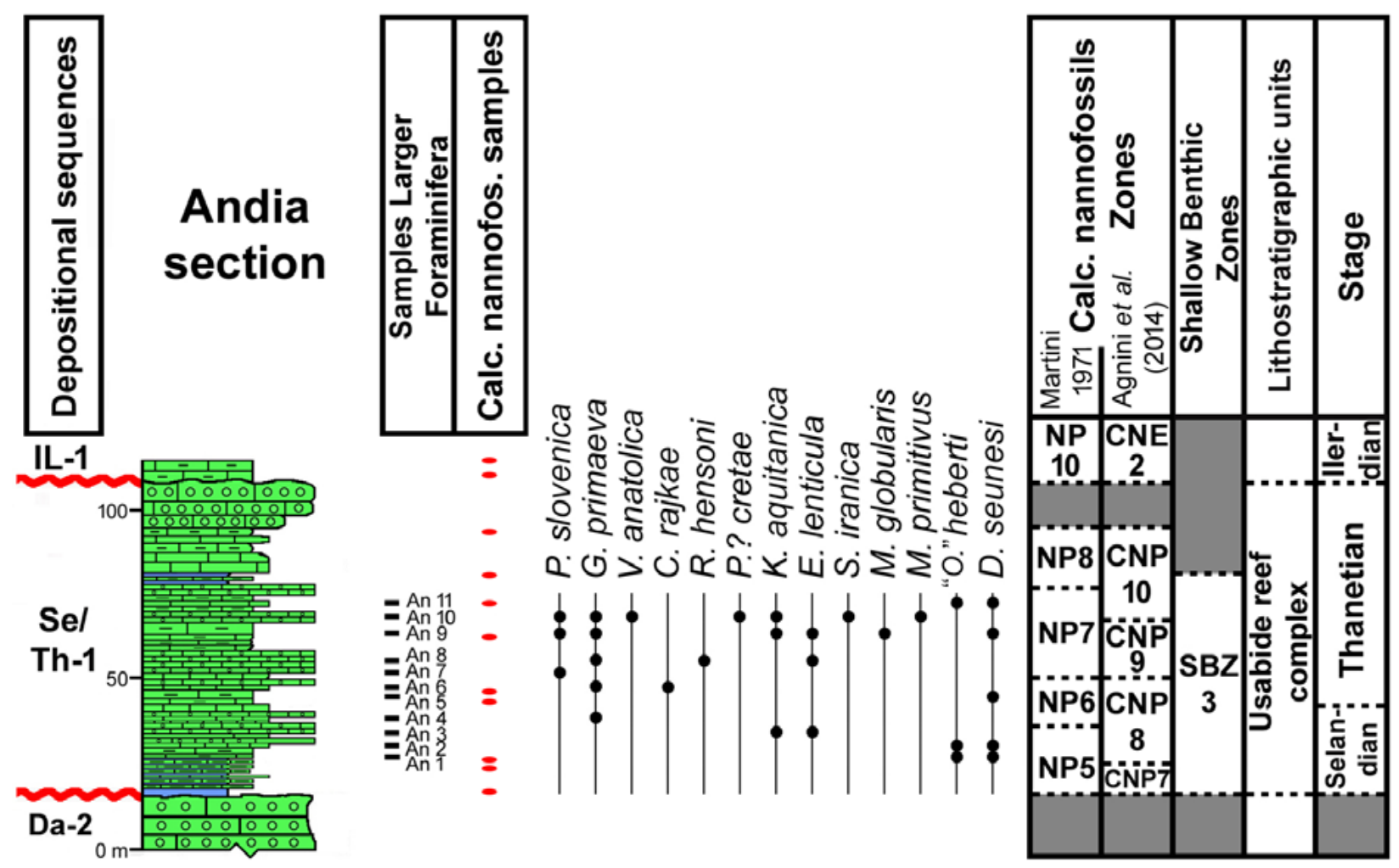

FIGURE 9. Stratigraphic succession and distribution of larger foraminifera in the Andia section. 
Da-1 DS. This unit is largely composed of marlstone and marly limestone. In the upper part, larger foraminifera such as S.? binkhorsti and P.? cretae were found, both without biostratigraphic interest. According to Baceta et al. (2005), the unit belongs to the lower part of NP3 zone with a basal hiatus spanning NP2 and probably the base of NP3. This is confirmed with data from laterally-equivalent deposits in the Unanua III and Baiza peak sections (see Baceta et al. 2005). Taking into account the zonation of Agnini et al. (2014), this interval belongs to the CNP3 zone. This indicates a basal hiatus between this and the former unit, which encompasses the biozone CNP2 and at least the lower half of CNP3.

Da-2 DS. This unit is mostly made up of near-massive limestones (reefal boundstones) with abundant colonial corals and calcareous algae (dasyclads, solenoporaceans and coralline red algae). These deposits contain abundant larger foraminifera, such as $K$. decastroi, $H$. paleocenica, $H$. elongata, E. dienii and $O$. moorkensii, characteristic of

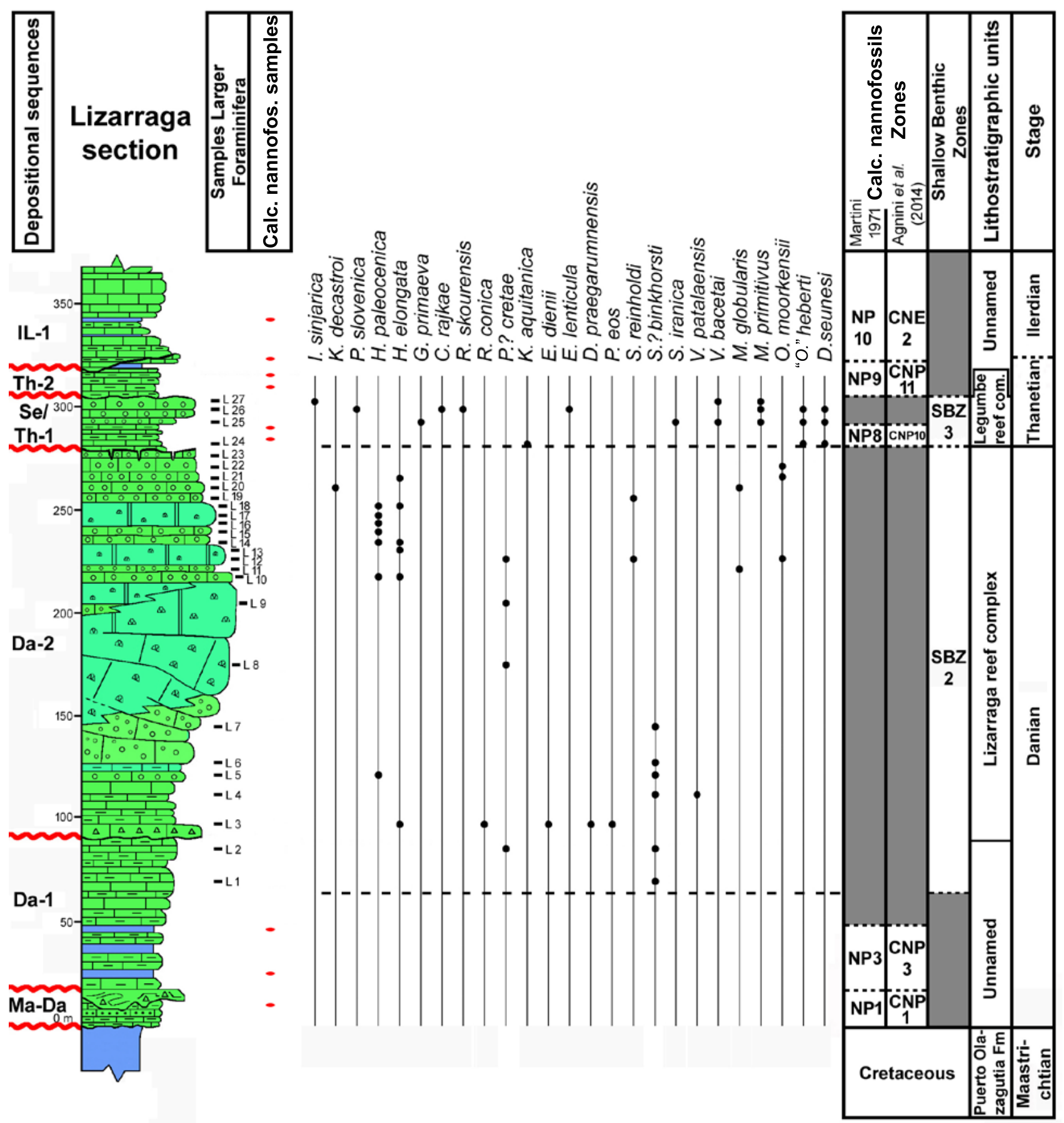

FIGURE 10. Stratigraphic succession and distribution of larger foraminifera in the Andia section. 
SBZ 2. According to Baceta et al. (2005), the unit belongs to the upper part of biozone NP3 as evidenced in laterallyequivalent deposits in the Unanua III section. The top of the unit is marked by a prominent discontinuity showing features of subaerial exposure, which is regionally known as the midPaleocene unconformity (Baceta et al., 2004, 2007).

Se/Th-1 DS. This is an up to 20-25m-thick and unit made up of marly limestones evolving vertically to bioclastic limestones. The latter are rich in larger foraminifera such as "O." heberti, D. seunesi and lessabundant $G$. primaeva, $C$. rajkae and $M$. primitivus, all representative of SBZ 3. This DS is laterally equivalent to the so-called Legumbe reef complex (Baceta et al., 2005). In the lower marly interval of the Se/Th-1 DS, Baceta et al. (2005) documented calcareous nannofossil assemblages representative of NP8 or CNP10 zones, and thus indicative of a Thanetian age.

Th-2 DS. This is a comparatively thin unit, mostly composed of marlstone and marly limestones of open platform deposits with abundant planktonic fossils, laterally-equivalent to the upper Thanetian "Assilina beds" (Baceta et al., 2005). Calcareous nannofossils are of late Thanetian age, specifically belonging to Zones NP9 or CNP11 (Baceta et al., 2005).

IL-1 DS. This unit is composed of marly limestone, marls and limestone. The NP10 or CNE2 (Eocene) age of this unit was established by Baceta et al. (2005).

\section{Urbasa Pass section}

Urbasa Pas section (Fig. 11) is located on the northern flank of the Urbasa-Andia synclinorium, along the NA-718 road from the Urbasa (Olazagutia) road pass to the Bidoiza campsite. It represents an up to $300 \mathrm{~m}$-thick Paleocene to lower Eocene succession belonging to marine platform facies lacking Selandian deposits.

UTM coordinates (ETRS89, H30) are: X: 546.182, Y: 4.727.412 (bottom) and X: 567.787, Y: 4.744 .504 (top).

The Paleocene rocks lie on erosional contact over the Maastrichtian Puerto de Olazagutia Fm. (Amiot, 1982). The Ma-Da DS has been informally called the "Solenomeris limestone", while the Th-2 was called the "Assilina beds" by Baceta et al. (2005). The same authors called the deposits of IL-1 DS the "Nummulites-Alveolina limestone".

Ma-Da DS. This unit is made of bioclastic limestones rich in the encrusting foraminifer Solenomeris sp., red algae (rhodophytes), bryozoans and B. hanseni indicating the SBZ 1 biozone.
Da-1 DS. This unit is composed of stratified to massive bioclastic limestone and reefal boundstones culminating with cross-bedded deposits. Most of these facies are affected by intense but patchy secondary dolomitization. This stratigraphic interval was informally defined as the Santa Marina reef complex by Baceta et al. (2005). The lesser-dolomitized beds contain $M$. globularis and $O$. moorkensii indicating SBZ 2 (lower part).

Da-2 DS. It is made in the lower half of cyclicallyordered bioclastic lagoonal limestones and marlstones, with patchy secondary dolomitization. These beds, interpreted as belonging to lagoonal facies, are laterally equivalent to the Lizarraga reef complex (Baceta et al., 2005). The bioclastic limestone beds contain $K$. decastroi, $H$. paleocenica, H. elongata and $M$. globularis, indicating SBZ 2 (upper part).

Se/Th-1 DS. The unit begins with a marlstonedominated interval that vertically evolves into bioclastic and massive red algae-coral boundstones overlain by bioclastic limestones, eventually with cross bedding and sandy intercalations. These beds are laterally equivalent to the Legumbe reef complex (Baceta et al., 2005). The DS contains a rich association of larger foraminifera, including G. primaeva, M. juliettae, M. primitivus, "O." heberti, $R$. soldadensis and D. seunesi, which belong to SBZ 3.

Th-2 DS. It is composed of marlstone and thin beds of bioclastic limestones. These contain numerous $A$. azilensis indicating SBZ 4.

IL-1 DS. It is characterized by bioclastic limestones with $A$. v. vredenburgi and $N$. gamardensis, indicating SBZ 5.

\section{Leortza section}

Leortza section (Fig. 12) is located along the A3114 road, in the river gorge located between the localities of Leortza/Elortza and Cicujano/Zekuiano, on the northern flank of the Maestu diapir. It encompasses a complete succession of shallow marine Maastrichtian to lowermost

Eocene carbonates and siliciclastic rocks. However, the present study focuses on the upper Paleocene interval (Se/ Th-1 and lower part of the Th-2 sequences).

UTM coordinates (ETRS89, H30) are X: 545.651, Y: 4.733.233 (bottom) and X: 545.722, Y: 4.733 .446 (top).

The stratigraphic interval represented by DS $S e / T h-1$ was informally called the "Legumbe reef complex", while the deposits of Th-2 DS were called the "Assilina beds" (Baceta et al., 2005). 
Se/Th-1 DS. This unit lies unconformably on dolomitized and karstified Danian deposits of the San Justi Fm. (Mangin, 1960) and begins with a thin and discontinuous bed of Qz-rich microconglomerates and sandy limestones. The bulk of the sequence consists of bioclastic limestones comprising a prominent interval, rich in red algae, bryozoans and corals, while stratified marlstones and dolomites occur atop. The presence of the larger foraminifera
$V$. anatolica, $C$. rajkae, $F$. alavensis, $M$. yvettae, M. juliettae, "O." heberti and D. seunesi among others indicates SBZ 3 for this stratigraphic interval. Additionally, it includes the type-locality beds of Fallotella alavensis.

Th-2 DS. This unit consists of bioclastic sandy silts with intercalations of bioclastic limestones rich in $A$. azilensis indicating SBZ 4.
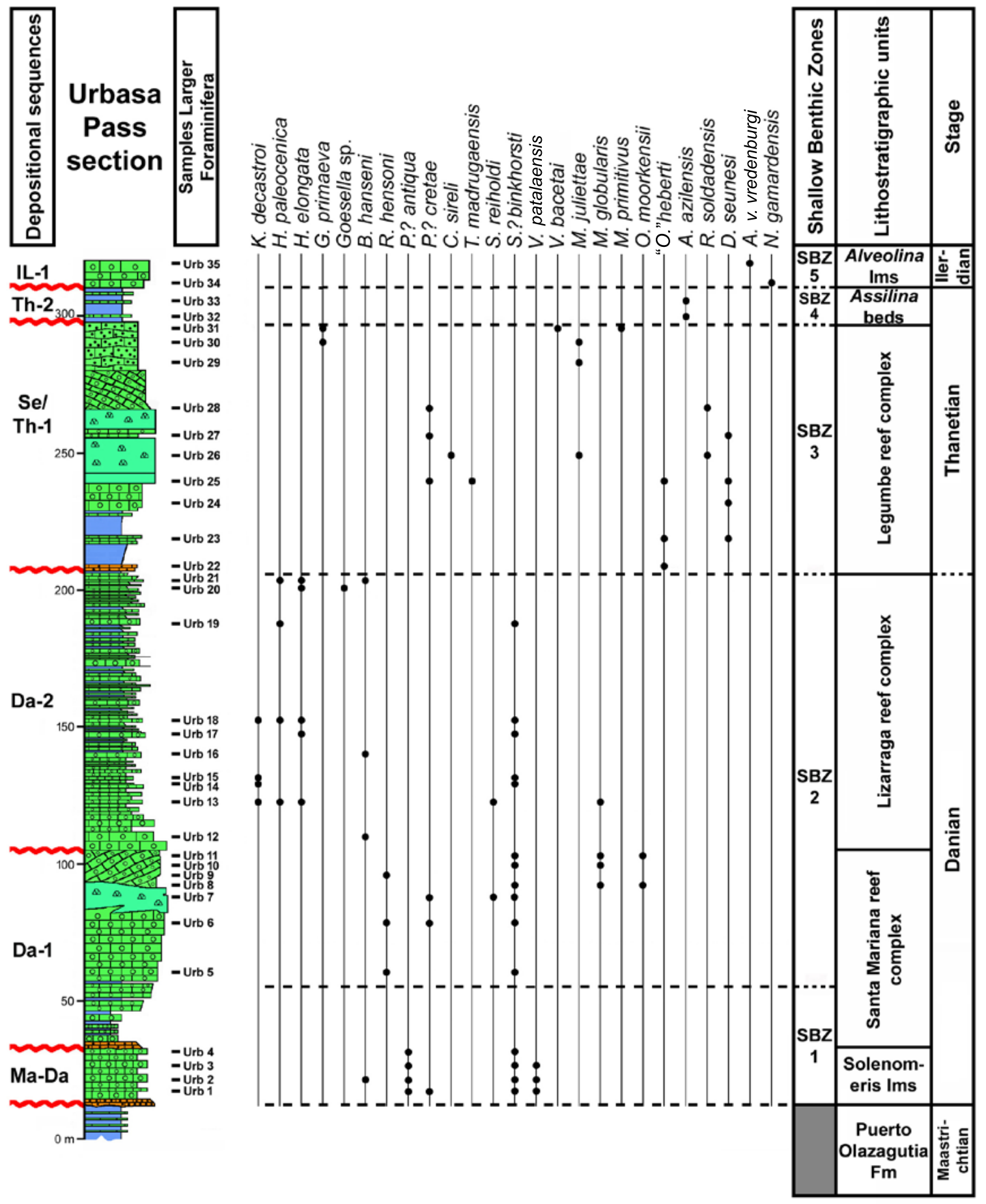

FIGURE 11. Stratigraphic succession and distribution of larger foraminifera in the Urbasa Pass section. 


\section{Korres section}

The section (Fig. 13) is located in some cliff outcrops 300m west of the town of Korres, close to the A-3138 road to Durruma Kampezu. The section comprises a complete succession of upper Paleocene to lower Eocene deposits (Th-2 and Il-1).

UTM coordinates (ETRS89, H30) are X: 546.182; Y: 4.727.412 (bottom) and X: 546.131; Y: 4.727 .608 (top).
The studied units overly a lower-middle Thanetian succession equivalent to the $\mathrm{Se} / \mathrm{TH}-1$ sequence at Leortza. The interval corresponding to the DS IL-1 was informally called the Ilerdian Alveolina limestone (Baceta, 1996).

Th-2 DS. The lower part of this unit is formed by sandy limestones with cross stratification, grey silt and sandy marlstone that vertically evolve into bioclastic limestones. This stratigraphic interval has been informally named the "Assilina
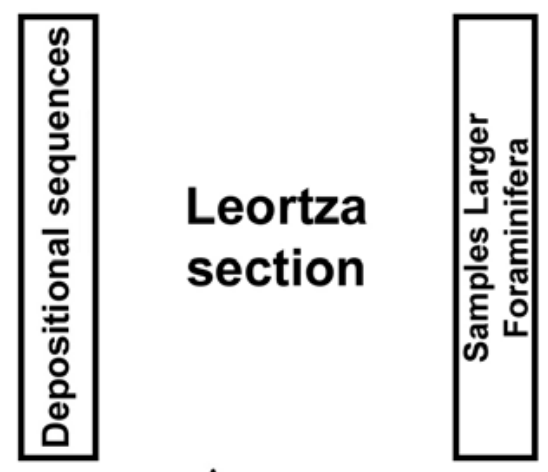

\section{Th-2}

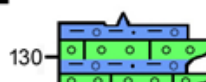

Leortza section

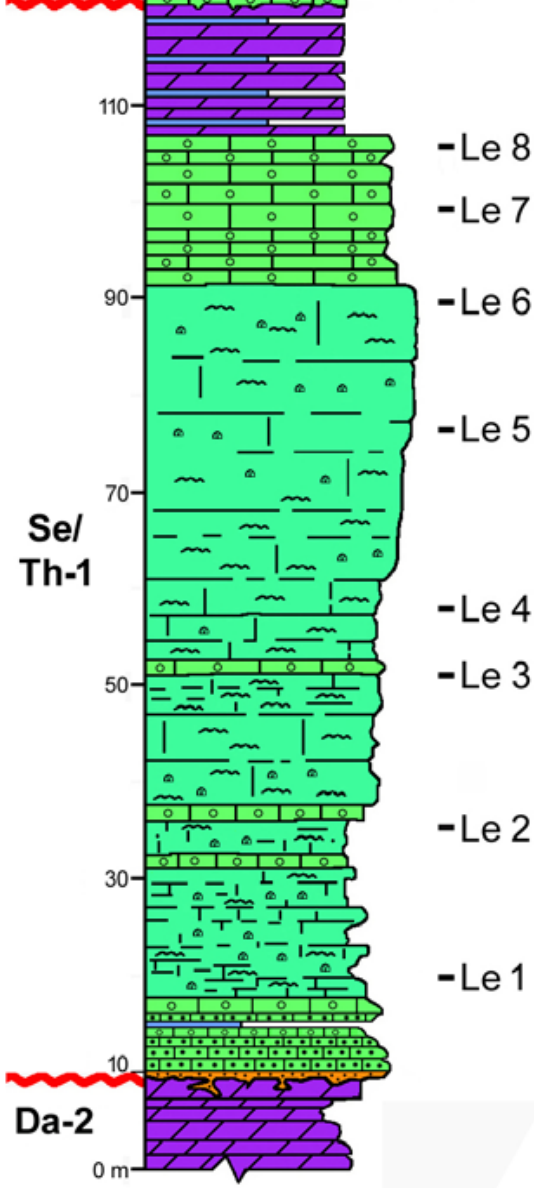

-Le 9

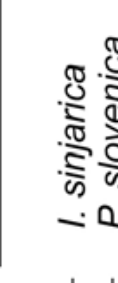

\section{西}
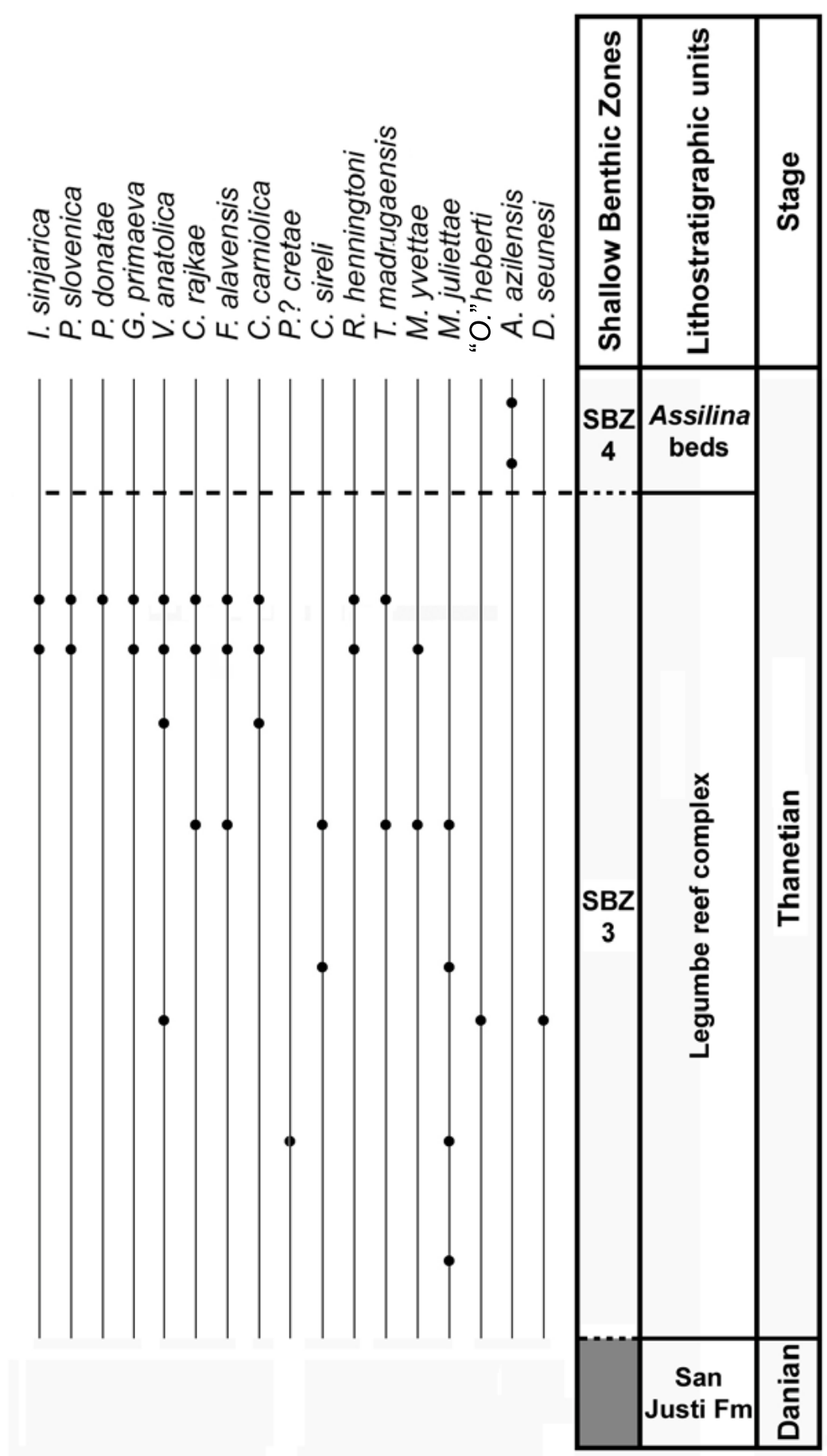

FIGURE 12. Stratigraphic succession and distribution of larger foraminifera in the Leortza section. 
beds" (Baceta et al., 2005). The top is a prominent paleokarst surface that defines the Paleocene-Eocene boundary (Baceta, 1996). The presence in this stratigraphic interval of $G$. levis, H. lukasi, D. garumnensis and A. yvettae indicates the SBZ 4. The sample $\mathrm{K} 2$ located in this DS is the type-locality of the new species: $A$. korresensis and $V$. bacetai.

IL-1 DS. It consists of a basal 6-7m-thick interval of unfossiliferous marlstone and sandy limestone with cross stratification overlain by bioclastic limestones including $A$. aramea aramea and $A$. v. vredenburgi which indicates SBZ 5.

\section{Aixola-Ermua section}

Aixola-Ermua section (Fig. 14) is a composite section from two laterally-equivalent outcrops
(Aixola-Egoarbitza and Ermua) located respectively on the southern and northern flanks of the Egoarbitza syncline (SE tip of the Biscay sinclinorium). Both are accessible from the town of Ermua, along the local GI-121 road to the Aixola dam and reservoir.

The Aixola-Egoarbitza section is located just north of the dam, with UTM coordinates (ETRS89, H30) X: 539.896, Y: 4.779.091 (bottom) and X: 539.924, Y: 4.779 .244 (top).

The Ermua section is located closer to the Ermua town, on the banks of the local road, with UTM coordinates (ETRS89, H30) X: 540.794, Y: 4.780 .716 (bottom) and X: 540.728, Y: 4.780 .681 (top).
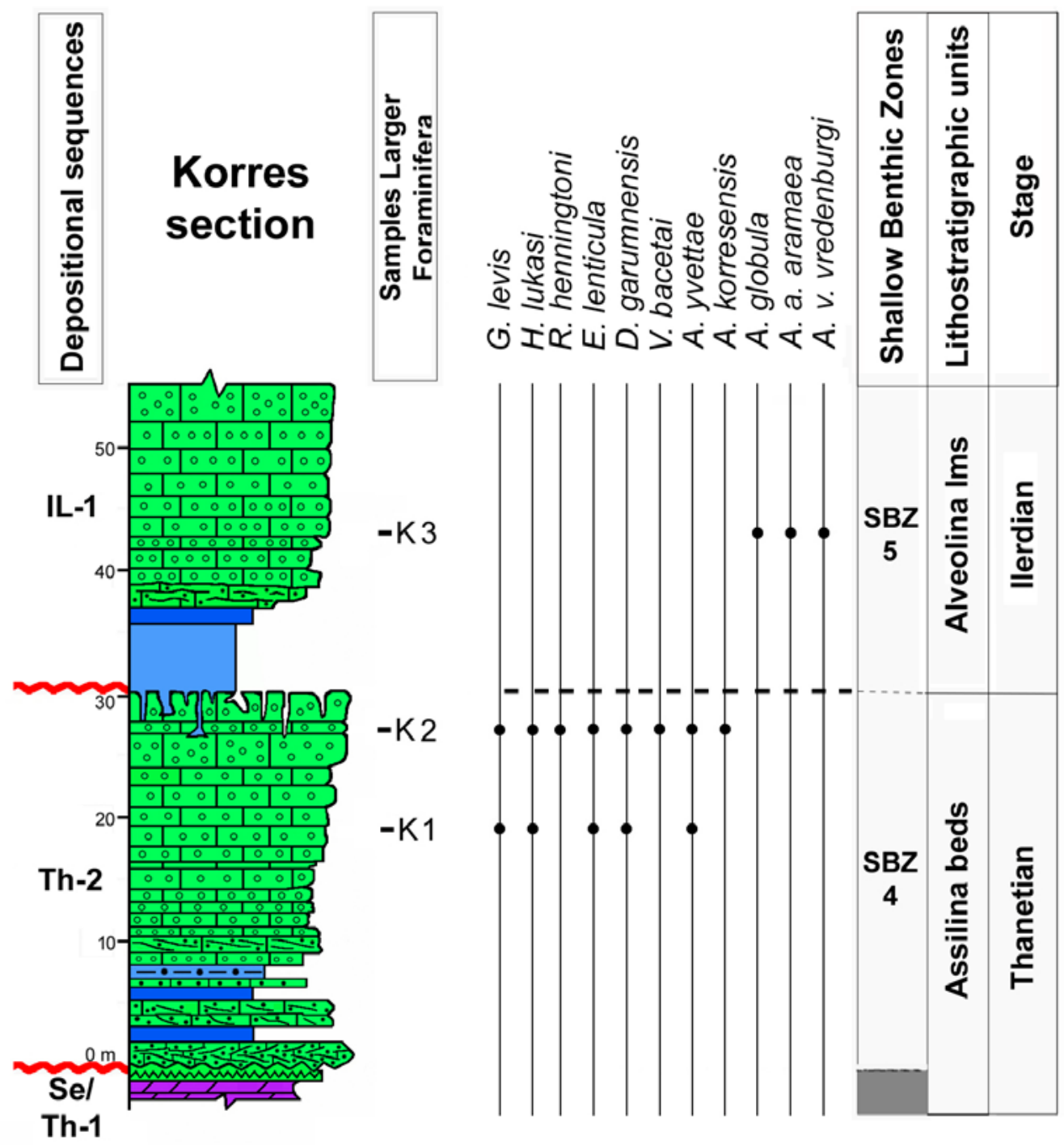

FIGURE 13. Stratigraphic succession and distribution of larger foraminifera in the Korres section. 
The underlying Maastrichtian deposits are marlstones with turbidite intercalations of the Urko Fm. (Mathey, 1982). In both outcrops, the Paleocene succession is a complex series of base-of-slope and basinal deposits, approaching $122 \mathrm{~m}$ in composite thickness, arranged in five DS. The deposits of the Da-1 and Da-2 DS belong to the Aitzgorri Fm. (Bernaola et al., 2009), while those of the Se/Th-1 and Th-2 DS belong to the Itzurun Fm. (Baceta et al., 2005).

Ma-Da DS. This unit is only well-exposed in some accessory outcrops to the east of the main Aixola outcrop, where it comprises $14 \mathrm{~m}$ of the upper Maastrichtian deposits, the $\mathrm{K} / \mathrm{Pg}$ boundary layer and $6 \mathrm{~m}$ of hemipelagic limestone with thin calcareous turbidites of earliest Danian age.

Da-1, Da-2, Se/Th-1 and Th-2 DS. All these units are bounded by discontinuity surfaces and internally consist of calcareous breccias deposits overlain by hemipelagic limestones and marlstones with interbedded platform and slope-derived calciturbidites and/or siliciclastic turbidites.

The occurrence of $E$. dienii and $M$. globularis in the Da-2 DS indicates SBZ 2, while the Se/Th-1 DS contains $G$. primaeva, $F$. alavensis, $R$. soldadensis and "O." heberti, indicating SBZ 3. The SBZ 4 biozone is characterized by $D$. garumnensis, E. subsphaerica, A. yvettae and $A$. azilensis observed in the Th-2 DS.

Calcareous nannofossil data from this study, allow the identification of the Selandian-Thanetian boundary in an interval a few meters above the NP5-NP6 zone boundary. This interval also records the first occurrence of " $O$." heberti (SBZ 3). The calcareous nannofossil assemblages studied here from the Da-2 and Se/Th-1 DS correspond to NP4, NP5, NP6, NP7 and NP8 of Martini (1971) and CNP6, CNP7, CNP8, CNP9 and CNP10 zones of Agnini et al. (2014) (Figure 14).

The upper part of the section (Th-2 DS and IL-1 DS) was previously studied by Monechi in Orue-Etxebarria et al. (1996), who attributed them to the calcareous nannoplancton Zones NP9 and NP10 respectively, which correspond to CNP11 and CNE1 of Agnini et al. (2014). The zonation of this section based on planktonic foraminifera was established by $\mathrm{X}$. Orue-Etxebarria in Pujalte et al. (1993).

IL-1 DS. The base of this sequence is an erosional discontinuity marking an abrupt change to clay-rich facies with turbidites of mixed composition containing larger foraminifera indicative of SBZ 5, such as $N$. cf. gamardensis. The geochemical signal of the CIE marking the Paleocene-Eocene boundary is located in the base of this DS according to Pujalte et al. (2009a, b).

\section{Urko section}

Urko section (Fig. 15) is located on the northern flank of the Biscay sinclinorium, on the eastern hillside of Urko peak, some $3 \mathrm{~km}$ north of the towns of Eibar and Ermua (Gipuzkoa province). The section is accessible along a path from the Ixua road pass, onthe GI-3950 road.

UTM coordinates (ETRS89, H30) are X: 541.754, Y: 4.783.428 (bottom) and X: 541.722, Y: 4.783 .390 (top).

Overlying the Monte Urko Fm. composed of typically reddish-purple hemipelagic rocks and above the $\mathrm{K} / \mathrm{Pg}$ boundary layer, there are grey-pinkish limestones and marlstones with numerous intercalations of platformderived calciturbidites belonging to the Danian stage (Baceta, 1996). This Danian succession is equivalent to the Aitzgorri limestone Fm. exposed in the type locality of Zumaia (Bernaola et al., 2009), and as there it can be subdivided into three intervals corresponding respectively to the Ma-Da, Da-1 and Da-2 DS. Their boundaries are conformity surfaces without recognizable stratigraphic hiatus.

The absence of larger foraminifera in most platformderived turbidites of the Ma-Da DS and the lower part of the Da-1 DS prevent a precise characterization of the SBZ1-SBZ2 boundary. SBZ 2 is indicated by the larger foraminifera $K$. decastroi, $E$. dienii, $O$. moorkensii and $P$. eos from the middle part of the Da-1 to the Da-2 DS.

Calcareous nannofossils of the 29 samples collected in the Danian of Urko section allowed the identification of four calcareous nannofossil zones defined by Martini (1971) for the Danian and the seven zones defined by Agnini et al. (2014) for the same interval (Fig. 5). Following the amendments introduced by Perch-Nielsen (1981, 1985), we have used the first occurrences of Cruciplacolithus primus large and Cruciplacolithus edwarsii to define the base of zones NP2 and NP3. Ellipsolithus macellus, whose first occurrence marks the base of NP4, is very scarce and it has a discontinuous distribution in the upper part of the section.

Systematic Palaeontology (J. Serra-Kiel and V. Vicedo)

Phylum: FORAMINIFERA d'ORBIGNY

Class Tubothalamea PAWLOWSKI et al., Order Miliolida (DELAGE AND HЙROUARD) Superfamily Milioloidea EHRENBERG Family Haurenidae SCHWAGER Subfamily Miliolinellinae VELLA

Genus Idalina SCHLUMBERGER AND MUNIER CHALMAS Type species: Idalina antiqua SCHLUMBERGER AND MUNIER-CHALMAS, 1884 


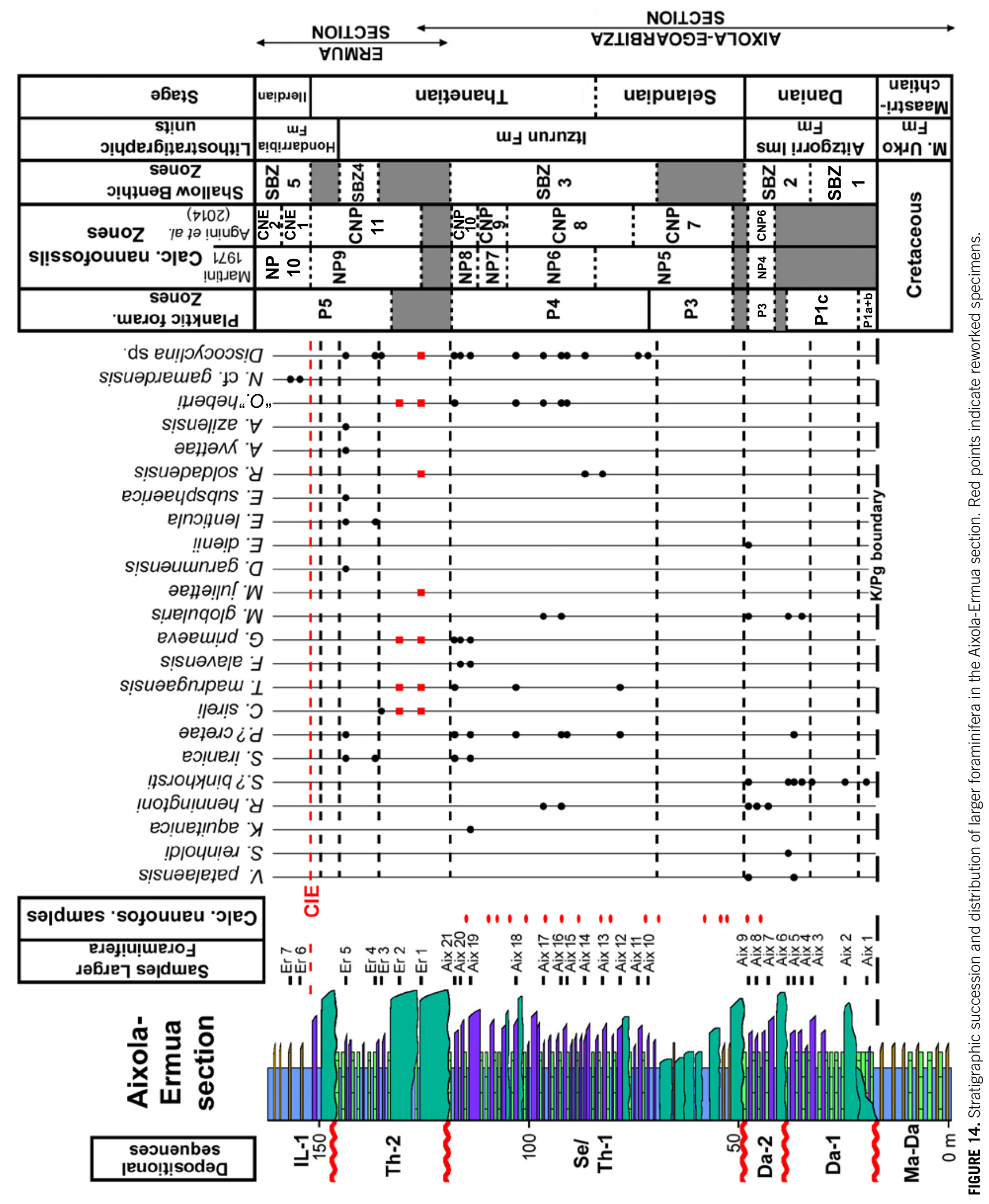




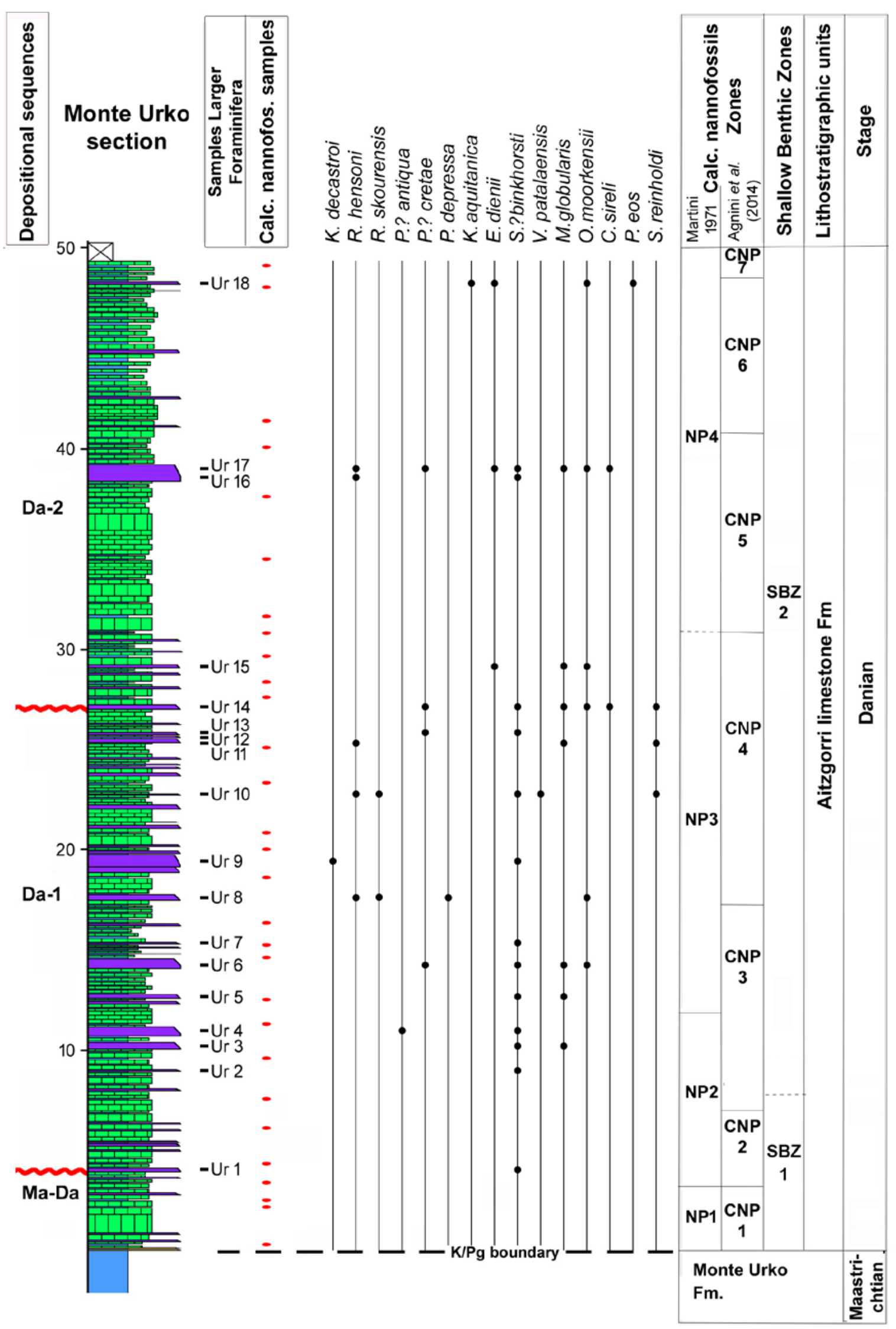

FIGURE 15. Stratigraphic succession and distribution of larger foraminifera in the Monte Urko section. 


\section{Idalina sinjarica GRIMSDALE, 1952} Figs. 16A-16D

1952 Idalina sinjarica. Grimsdale, p. 230, pl. 1, fig. 1-13; pl. 12, fig. 1,2; pl. 13, fig. 2; pl. 14, fig. 1 1974 Idalina sinjarica GRIMSDALE. Drobne, p. 166-167; pl. 1, fig. 1-2, 4-13

1998 Idalina sinjarica GRIMSDALE. Sirel, p. 55-56; pl. 17, fig. 1-23

2001 Idalina sinjarica GRIMSDALE. Özgen and Akyazi, pl. 1, fig. 12-13; pl. 2, fig. 1

2008 Idalina sinjarica GRIMSDALE. Pignatti et al., pl. 5, fig. 4; pl. 7, fig. 11

2010 Idalina sinjarica GRIMSDALE. Di Carlo et al., p. 54-55; pl. 4, figs. 1-19

2015 Idalina sinjarica GRIMSDALE. Sirel, pl. 19; figs. $1-23$

Material. Sample Se 1 from Serraduy section (Fig. 4); samples Cm 5 and Cm 8 from Campo section (Fig. 5); samples Te 3 and Te 4 from Tena section (Fig. 6); sample L 27 from Lizarraga section (Fig. 10); samples Le 7 and Le 8 from Leortza section (Fig. 12) and sample Coll 3 from Collarada section (Robador, 2005, Annex p. 22-23).

Description. Test porcelaneous with ovoid morphology and miliolid growth. Dimorphism marked. The megalospheric forms show an elliptical outline in longitudinal section and subcircular outline in perpendicular section. The major diamenter for three whorls is $0.8 \mathrm{~mm}$ and $1.25 \mathrm{~mm}$ for four whorls. The proloculus is spherical, 140 $170 \mu \mathrm{m}$ in diameter, with a flexostyle followed by chambers in quinqueloculine arrangement, becoming bilocular in later stages of growth. The trematophore is supported by thin pillars (Fig. 16B-16D). The undulate basal layer does not exceed half of the chamber height (Fig. 16B-16D). The microspheric generation has a thick basal layer and a subcircular outline in axial section (Fig. 16).

Distribution. This species has been identified in $\mathrm{Se} /$ Th-1 DS of the following sections: Serraduy section (Fig. 4); Campo section (Fig. 5); Tena section (Fig. 6); Lizarraga section (Fig. 10) and Leortza section (Fig. 12) with the species assemblage indicated in the aforementioned figures.

Biozone. Drobne (1974) identified this species in rocks from Slovenia considered as belonging to the interval from $G$. primaeva Zone to A. ellipsoidalis Zone. According to Serra-Kiel et al. (1998), its biostratigraphic range extends from SBZ 3 to SBZ 6. In this work $I$. sinjarica is associated to assemblages belonging to the SBZ 3.

\section{Genus Kayseriella SIREL Type species: Kayseriella decastroi SIREL}

\section{Kayseriella decastroi SIREL, 1998 Fig. 16E-16H}

1988 “Scandonea". Drobne et al., pl. 25, fig. 7 1998 Kayseriella decastroi Sirel, p. 57-58; pl. 16, fig. 19-23; pl. 20, fig. 1-11; pl. 21, fig. 1-12; pl. 22, fig. 1-15 1999 Kayseriella decastroi Sirel, p. 128; pl. 1, fig. 1-11; pl. 2 fig. 1-12; pl. 3, 1-15

2001 Kayseriella decastroi SIREL, Ogorelec et al., pl. 9, fig. 4-7

2004 Kayseriella decastroi SIREL, p. 60-61; pl. 55, figs. 1-11; pl. 56, figs. 1-12; pl. 57, figs. 1-15

2009 Kayseriella decastroi SIREL, pl. 2, figs. 1-7

2010 Kayseriella decastroi SIREL, Di Carlo et al., p. 54; pl. 1, fig. 2

2012 Kayseriella decastroi sirel, pl. 1, figs. 19-23

2015 Kayseriella decastroi SIREL, pl. 1, figs. 19-23; pl. 6; figs. 1-12

2018 Kayseriella decastroi SIREL, pl. 43, figs. 1-12

Material. Sample L 20 from Lizarraga section (Fig. 10); samples Urb 13, Urb 14, Urb 15 and Urb 18 from Urbasa Pass section (Fig. 11); sample Ur 9 from Urko section (Fig. 15) and samples Ain 5 and Ain 30 from Aintzioa section (Robador, 2005, Annex, p. 64-65).

Description. Test porcelaneous with lenticular, flat morphology. The proloculus has a diameter of $70 \mu \mathrm{m}$ followed by 8-9 planispiral chambers (Fig. 16F, H). The single aperture, located at the bottom of the apertural face, shows a peristome (Fig. 16E, H). Later stage of growth composed of chambers arranged in an uncoiled-uniserial pattern with cribrate apertures. Microspheric forms not found.

Distribution. This species is present in Da-1 DS of the Urko section (Fig. 15), , in the Da-2 DS of the Lizarraga section (Fig. 10), and in the Urbasa Pass section (Fig. 11), with the species assemblage indicated in the aforementioned figures.

Biozone. Sirel (1998) found this species in Danian rocks from Turkey. Later, Ogorelec et al. (2001) found it in the Danian and Selandian from Slovenia. According to the data presented herein this species can be considered as a marker of the SBZ 2.

\section{Family Fabulariidae EHRENBERG Genus Periloculina MUNIER-CHALMAS AND SCHLUMBERGER \\ Type species: Periloculina zitteli MUNIER-CHALMAS AND SCHLUMERGER}

Periloculina slovenica DROBNE, 1974

Fig. 16I-16L 


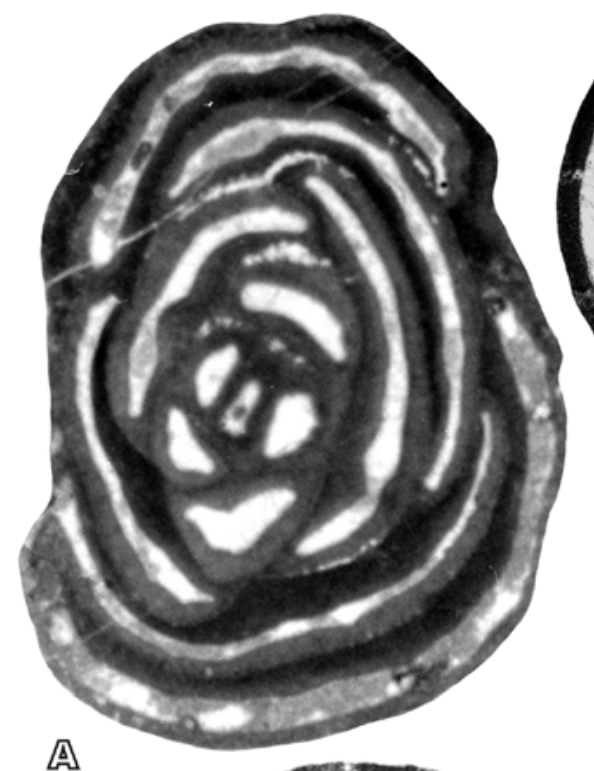

远
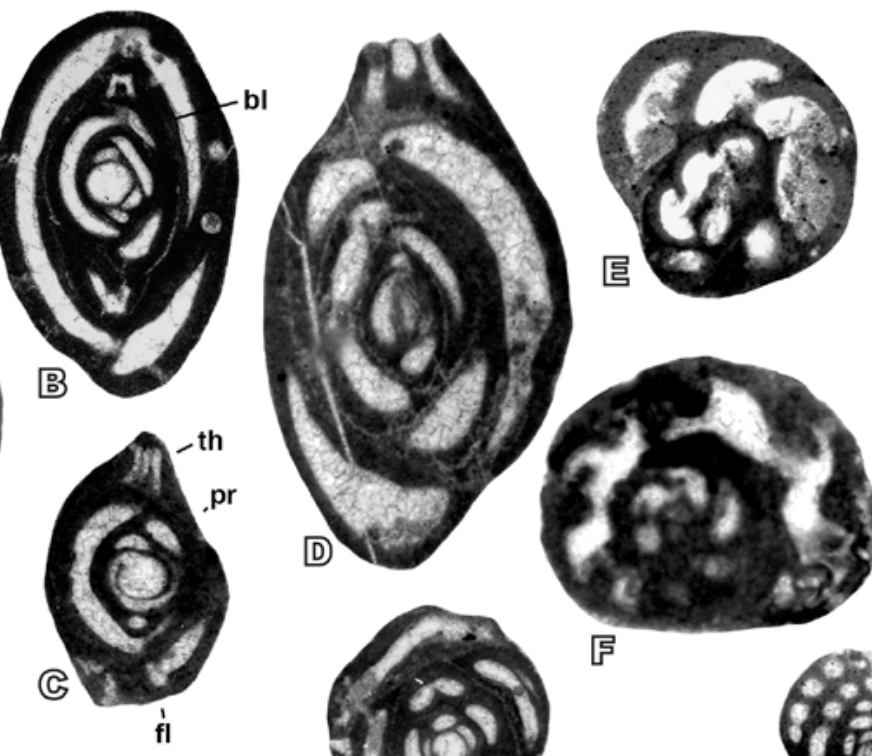

(a)
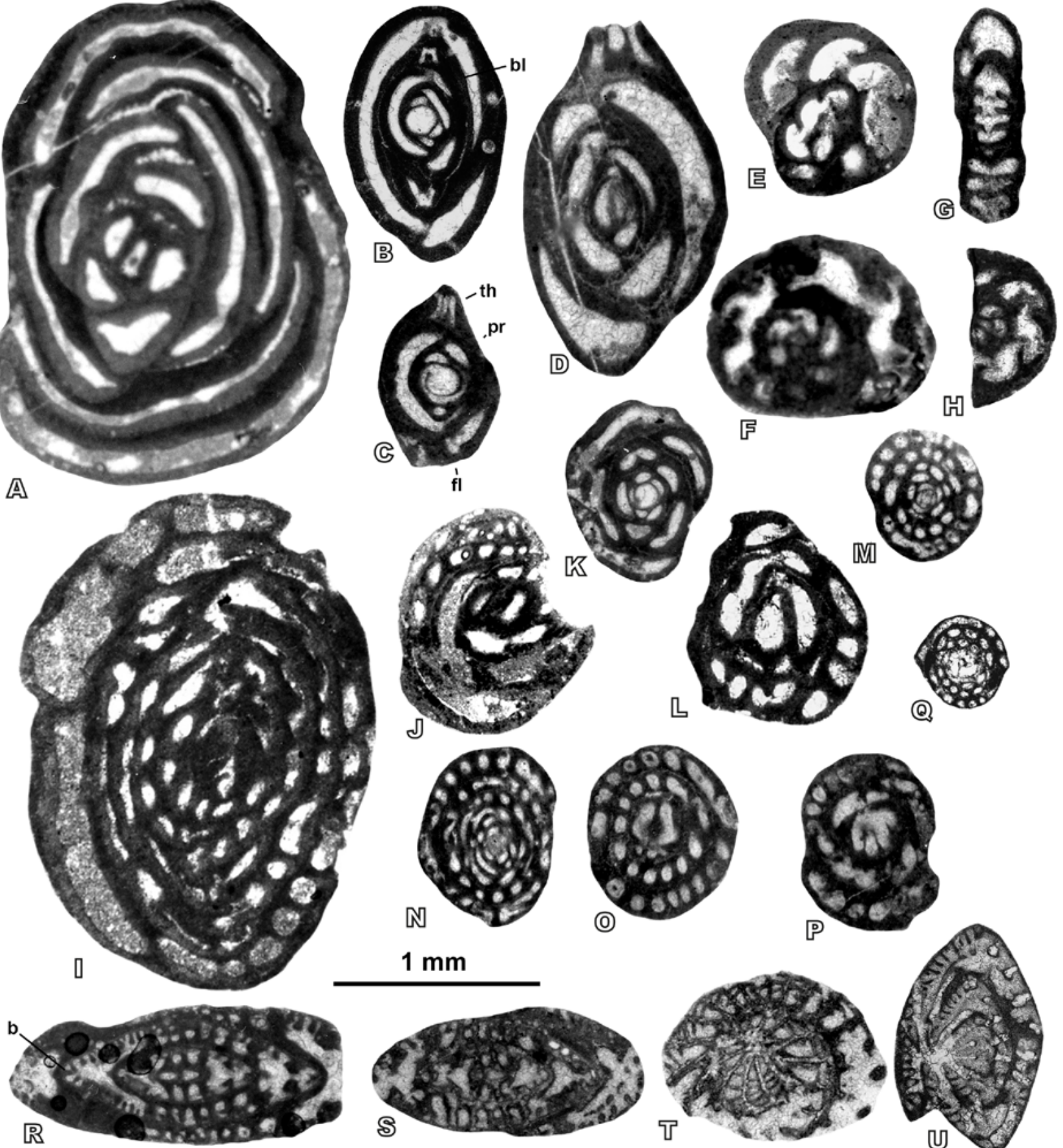

$1 \mathrm{~mm}$

(0)

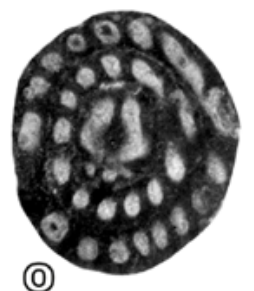

Q

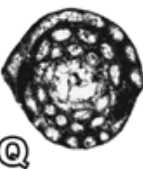

ᄂ

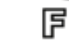

以

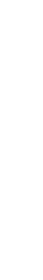


1974 Periloculina slovenica. Drobne, p. 173-175, textfig 12c, d; pl. 11, fig. 1-10; pl. 12, fig. 1

1984 Periloculina slovenica DROBNE. Drobne, p. 1419; pl. 4, fig. 1-15; pl. 5, fig. 1-7; pl. 6, fig. 1-9

2001 Periloculina slovenica DROBNE. Özgen and Akyazi, pl. 1, fig. 14; pl. 2, fig. 1

2010 Periloculina slovenica DROBNE. Di Carlo et al., p. 55-56; pl. 4, figs. 20-27, 29-33.

Material. Samples $\mathrm{Cm} 5$ and $\mathrm{Cm} 8$ from Campo section (Fig. 5); samples Te 3 and Te 4 from Tena section (Fig. 6); samples An 7, An 9 and An 10 from Andia section (Fig. 9); sample L 26 from Lizarraga section (Fig. 10) samples Le 7 and Le 8 from Leortza section (Fig. 12) and sample Coll 3 from Collarada section (Robador, 2005, Annex, p. 22-23).

Description. The test is porcelaneous with ovoid morphology and miliolid growth. The dimorphism is strong. The megalospheric generation begins with a flexostylic proloculus, of around $150 \mu \mathrm{m}$ in diameter, followed by chambers in triloculine arrangement (Fig. 16K). The basal layer forms longitudinal ridges, occasionally reaching the chamber roof (Fig. 16I-J, L). The microspheric form has a longitudinal length of $2.4 \mathrm{~mm}$ and an axial diameter of about $1.75 \mathrm{~mm}$.

Distribution. This species is found in Se/Th-1 DS of the Campo section (Fig. 5), Tena section (Fig. 6), Andia section (Fig. 9), Lizarraga section (Fig. 10) and Leortza section (Fig. 12), with the species assemblage indicated in the aforementioned figures.

Biozone. Drobne (1974) identified this species in Thanetian rocks ( $G$. primaeva Zone) from Slovenia. As pointed out by Serra-Kiel et al. (1998) its biostratigraphic range is SBZ 3. This species can be considered as a marker for SBZ 3.

\section{Genus Pseudolacazina CAUS \\ Type species: Pseudolacazina hottingeri caus}

\section{Pseudolacazina donatae (DROBNE, 1974) Fig. 16M-Q}

1974 Fabularia donatae Drobne, p. 167-169; text fig. 9, a-b; pl. 2, fig. 1-6; pl. 3, fig. 1-3 ; pl. 4, fig. 1-9, 7-21; pl. 9, fig. 1; pl. 13, fig. 1; pl. 14, fig. 1; pl. 15, fig. 1-2

1998 Pseudolacazina donatae (DROBNE). Sirel, p. 6162; pl. 27, fig. 1-15

2008 Pseudolacazina donatae (DROBNE). Pignatti et al. pl. 7, fig. 12

2009 Pseudolacazina donatae (DROBNE). Sirel, pl. 3, figs. 9-13
Material. Samples $\mathrm{Cm} 5$ and $\mathrm{Cm} 8$ from Campo section (Fig. 5); samples Te 4 and Te 5 from Tena section (Fig. 6); sample Le 8 from Leortza section (Fig. 12) and sample Coll 3 from Collarada section (Robador, 2005, Annex, p. 22-23).

Description. Porcelaneous test with spherical morphology and miliolid growth. The dimorphism is marked. Megalospheric forms have an outline elliptical in longitudinal section and subcircular in perpendicular section (Fig. 16Q). The proloculus is spherical with a diameter of $140 \mu \mathrm{m}$ followed by chambers in biloculine arrangement. The basal layer forms numerous longitudinal partitions subdividing chambers into chamberlets (Fig. 16M, N, Q). Microspheric forms not found.

Distribution. This species is found in Se/Th-1 DS of the Campo section (Fig. 5), Tena section (Fig. 6) and Leortza section (Fig. 12), with the species assemblage indicated in the aforementioned figures.

Biozone. Drobne (1974) found this species in the $G$. primaeva Zone and in the A. ellipsoidalis Zone in rocks from Slovenia. Drobne in Serra-Kiel et al. (1998) extended the biostratigraphic range from SBZ 4 to SBZ 6 . In the material studied $P$. donatae is associated with species typical of the SBZ 3. Consequently, we extend its biostratigraphic range from SBZ 3 to SBZ 6.

\section{Family Soritidae EHRENBERG Subfamily Praerhapydioninae HAMAOUI AND FOURCADE \\ Genus Haymanella SIREL Type species: Haymanella paleocenica SIREL}

\section{Haymanella paleocenica SIREL, 1998 Fig. 17A-M}

1998 Haymanella paleocenica Sirel, p. 36-37; pl. 2, fig. 1-18; pl. 3, figs. 1-12

1999 Haymanella paleocenica sp., Sirel, p. 124, 126; pl. 4, figs. 1-18; pl. 5, figs. 1-13, 2001 Haymanella paleocenica Sirel. Ogorelec et al. pl. 9, figs. 1-3 2004 Haymanella paleocenica. Sirel, p. 66; pl. 61, figs. 1, 3, 5-9, 11, 13, 15-18; pl. 67, figs. 1, 5-9, 11, 12 2010 Haymanella paleocenica Sirel, Di Carlo et al. p. 62-63; pl. 1, figs. 5, 6; pl. 5, fig. 17

2015 Haymanella paleocenica Sirel pl. 4, figs. 7-18 2018 Haymanella paleocenica Sirel, pl. 48, figs. 7-18

Material. Samples L 5, L 10, L 14, L 15, L 16, L 17 and L 18 from Lizarraga section (Fig. 10) and samples Urb 13, Urb 18, Urb 19 and Urb 21 from Urbasa Pass section (Fig. 11). 
Description. The test is porcelaneous with elongate, cilindrical to high conical morphology in the adult forms. The wall is thick and contains agglutinated grains on the surface. The embryonic and nepionic stages have not been adequately observed. The ephebic stage is composed of chambers in uniserial arrangement, showing a maximum length of $2.25 \mathrm{~mm}$ and a diameter of $0.65 \mathrm{~mm}$ for 8 uniserial chambers (Fig. 17A). The sutures are slightly depressed. The aperture is single, with a star-shaped outline (Fig. 17M) and located in interiomarginal position (Fig. 17H-J) in planispiral chambers, while it occurs in terminal position in the uniserial chambers (Fig. 17A-C, E-F).

Distribution. This species has been identified in Da-2 DS in the Lizarraga section (Fig. 10) and in Urbasa Pass section (Fig. 11) with the species assemblage indicated in the aforementioned figures.

Biozone. Sirel (1998) found this species in the Danian rocks from Turkey. Ogorelec et al. (2001) found it in the Danian and Selandian from Slovenia. According the data presented here this species can be considered as a marker of the SBZ 2.

\section{Haymanella elongata SIREL, 2009}

Fig. 17N-17V

1999 Haymanella paleocenica. Sirel, p. 124, 126; pl. 4, figs. 4, 10, 12, 14, 18; pl. 5, figs. 1-4, 8-10

2009 Haymanella elongata. Sirel, p. 416-418; pl. 1, figs. 11-17

2015 Haymanella elongata. Sirel, pl. 5, figs. 1-12

2018 Haymanella elongata. Sirel, pl. 49, figs. 1-12

Material. Samples L 3, L 10, L 13, L 14, L 18 and L 21 from Lizarraga section (Fig. 10) and samples Urb 13, Urb 17, Urb 18, Urb 20 and Urb 21 from Urbasa Pass section (Fig. 11).

Description. The test is porcelaneous with elongate morphology and thick wall. The embryonic apparatus has

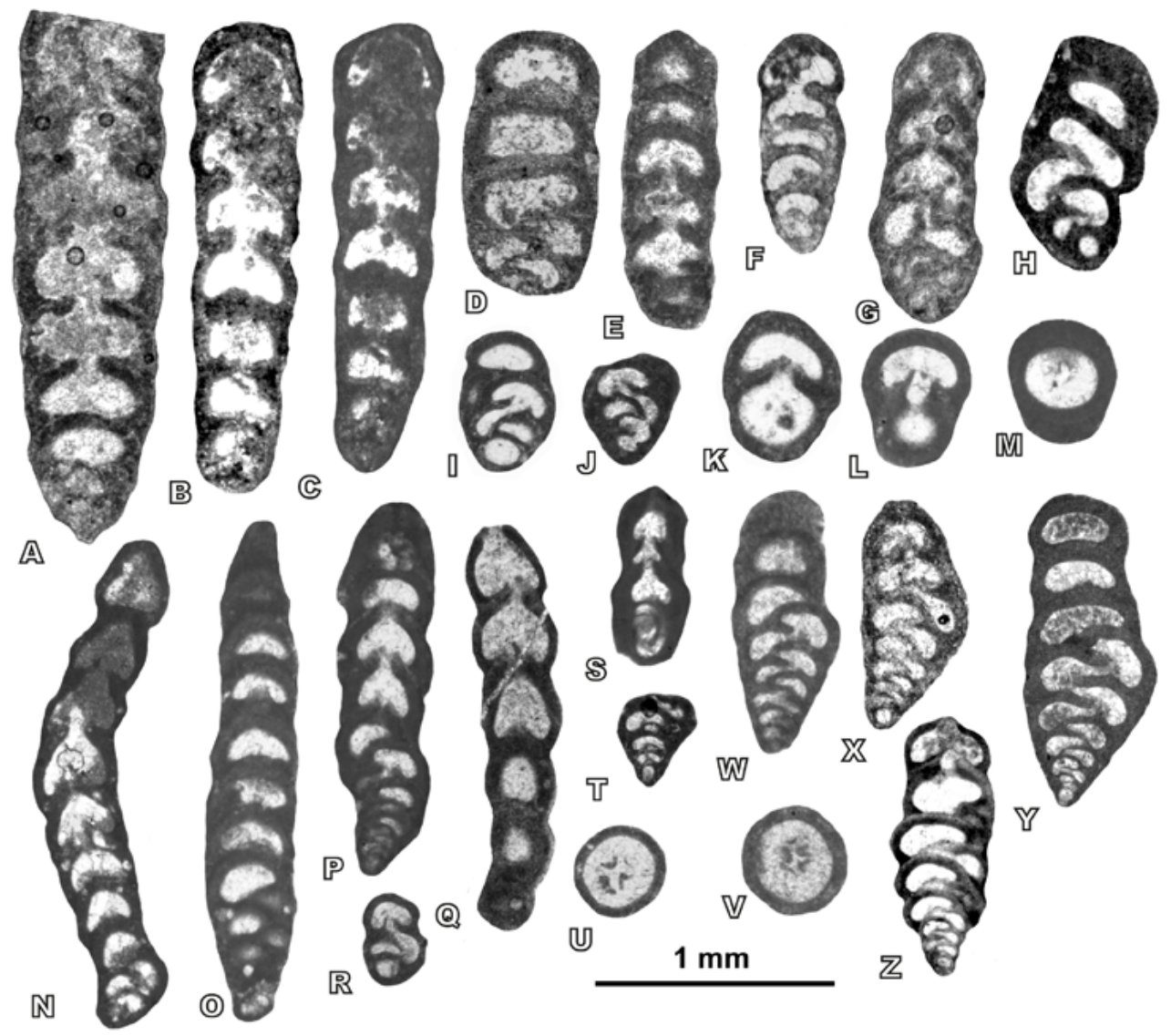

FIGURE 17. Paleocene Larger Foraminifera from the Pyrenean Basin. A-M: Haymanella paleocenica SIREL, 1999 A-G uncentered longitudinal sections; $\mathbf{H}$ centered longitudinal section; I-J nepionic longitudinal sections; K-L oblique sections, note the aperture; $\mathbf{M}$ horizontal section, note the star-shaped outline of the aperture. Specimens A, E, G and $H$ from sample L 5; B and C from sample Urb 13; D from sample L 15; F from sample L 17; I and K from sample L 14; J from sample L 18; L and M from sample Urb 18. N-V: Haymanella elongata SIREL, 2009 N-Q longitudinal sections; R-T nepionic stage; U-V horizontal section, note the star-shaped outline of the aperture. Specimen N from sample Urb 13; 0 from sample Urb 18; $P$ and S from sample Urb 20; Q from sample L 18; R and T from sample L 21; U from sample L 14 and V from sample L 13. W-Z: Praerhapydionininae indet. centered longitudinal sections. Specimen W from sample Urb 19 and X-Z from sample L 21. 
not been adequately observed. The nepionic stage of growth consists of chambers planispirally arranged (Fig. 17S). The ephebic stage shows uniserial chamber arrangement, with a maximum longitudinal section of $1.6 \mathrm{~mm}$ and a diameter of $0.35 \mathrm{~mm}$ with 8 uniserial chambers (Fig. 170). The single, star-shaped aperture is located in interiomarginal position in the nepionic stage (Fig. 17R) and in terminal position in the ephebic stage (Fig. 17P, Q)

Distribution. This species appears in Da-2 DS of the Lizarraga section (Fig. 10) and the Urbasa Pass section (Fig. 11) with the species assemblage indicated in the aforementioned figures.

Biozone. SIREL (2009) found H. elongata in Danian and Selandian from Turkey. In the material studied, this species can be considered as a marker for the SBZ 2.

\section{Praerhapydionininae indet. Fig. 17W-Z}

Material. Samples An 3, An 4, An 8 and An 11 from Andia section (Fig. 8); sample L 21 from Lizarraga section (Fig. 10) and sample Urb 19 from Urbasa Pass section (Fig. 11).

Description. Porcelaneous test with a thick wall. Aperture single with subcircular outline. The embryo is composed of a spherical proloculus with a diameter of $62 \mu \mathrm{m}$. The nepionic stage is composed of 9-10 chambers biserially arranged (Fig. 17W-Z), ephebic of around 3-4 chambers arranged uniserially (Fig. 17Y-Z). Chamber lumen not subdivided. Sutures slightly depressed (Fig. 17Y-Z). Dimorphism not observed.

Remarks. The wall texture and the uniserial ephebic chamber arrangement suggest that this species belongs to the subfamily Praerhapydionininae; however, the biserial nepionic chamber arrangement is different from the planispiral coiling of the other genera ascribed to this subfamily. The Cretaceous genus Pseudorhapydionina DE CASTRO, 1971 with nepionic biserial arrangement, has cribrate aperture and a well-developed exoskeleton. The lack of sufficient material leads to leave these specimens undetermined.

Distribution. This species is present in the depositional sequences Da-2 DS from Urbasa Pass section (Fig. 11), Se/Th-1 DS from Andia section (Fig. 9) and in Lizarraga section (Fig. 10) with the species assemblage indicated in the aforementioned figures.

Biozone. This species was found associated to assemblages of larger foraminifera that belong to the SBZ 2-SBZ 3 (Fig. 9).

\section{Family Meandropsinidae HENSON \\ Genus Hottingerina DROBNE \\ Type species: Hottingerina lukasi, DROBNE}

\section{Hottingerina lukasi DROBNE, 1975 \\ Fig. 16R-U.}

1975 Hottingerina lukasi. Drobne, p. 224-248; pl. 1; pl. 2, fig. 1-2; pl. 3; pl. 4, fig. 1-9; pl. 6, fig. 15; pl. 7, fig. 1; pl. 8; pl. 9; pl. 10, fig. 1-2

2010 Hottingerina lukasi DroBNE. Di Carlo et al., p. 64; pl. 6, figs. $1-3$.

Material. Samples K 1 and K 2 from Korres section (Fig. 13).

Description. The test is porcelaneous with lenticular morphology and planispiral involute growth. The maximum equatorial diameter observed is about $1.65 \mathrm{~mm}$ and the wall is $0.8 \mathrm{~mm}$-thick. The endoskeleton consists only of a thin basal layer. The exoskeleton is composed of short beams (Fig. 16R-S). The aperture is located at the base of the septum.

Remarks. The embryonic architecture of this species could not be observed in the material studied due to the lack of a centred section.

Distribution. This species has been identified in the Th-2 DS from the Korres section (Fig. 13) with the species assemblage indicated in the aforementioned figures.

Biozone. Drobne (1975) and Drobne in Serra-Kiel et al. (1998) considered this species as belonging to the SBZ 4 , from which it can be considered as a marker.

\section{Superfamily Alveolinoidea EHRENBERG Family Alveolinidae EHRENBERG Genus Glomalveolina HOTTINGER Type species: Alveolina dachelensis SCHWAGER}

Glomalveolina primaeva (REICHEL, 1937) Fig. 18A-H

1937 Alveolina primaeva. Reichel, p. 88-91, fig. 17; text fig. 15; pl. 9, fig.4-5

1960 Alveolina (Glomalveolina) primaeva REICHEL.

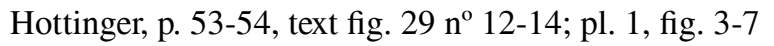
1974 Alveolina (Glomalveolina) primaeva REICHEL. Hottinger, p. 34-35; pl. 31, figs. 8-9

1977 Alveolina (Glomalveolina) primaeva REICHEL. Drobne, p. 13-14, text fig. 1a-d

1983 Alveolina (Glomalveolina) primaeva REICHEL. Rahaghi, p. 49, pl. 21, fig. 1-3

1998 Alveolina (Glomalveolina) primaeva REICHEL. 
Sirel, p. 63-64; pl. 29, fig. 5-6, 10-11, 13

2008 Glomalveolina primaeva (REICHEL). Sirel and Acar, p. 5; pl. 1, figs. 1-6

2008 Glomalveolina primaeva (REICHEL). Pignatti et al. pl. 5, fig. 5; pl. 7, fig. 8a-b

2009 Glomalveolina primaeva (REICHEL). Sirel, pl. 6, fig. 12

2010 Glomalveolina primaeva (REICHEL). Di Carlo et al. p. 57-58; pl. 5, figs. 1-5, 7-13, 14B, 15, 16

2015 Glomalveolina primaeva (REICHEL). Sirel, pl. 17, figs. 5-6, 10-13

2018 Glomalveolina primaeva (REICHEL). Sirel, pl. 30, figs. 4-5.

Material. Sample Se 1 from Serraduy section (Fig. 4); samples Cm 3 and Cm 8 from Campo section (Fig. 5); samples Te 3, Te 4 and Te 5 from Tena section (Fig. 6); samples An 4, An 6, An 8, An 9 and An 10 from Andia section (Fig. 9); sample L 25 from Lizarraga section (Fig. 10); samples Le 7 and Le 8 from Leortza section (Fig. 12); samples Urb 30 and Urb 31 from Urbasa Pass section (Fig. 11) and samples Aix 19, Aix 20, Aix 21, Er 1 and Er 2 from Aixola-Ermua section (Fig. 14).

Description. The test is porcelaneous with subspherical morphology. Megalospheric forms show an embryo formed of a proloculus with a diameter of about $85-90 \mu \mathrm{m}$ (Fig. 18F, G) and a flexostyle, followed by the nepionic stage consisting of chambers with streptospiral growth. This nepiont stage has a diameter of around $220-250 \mu \mathrm{m}$. The possible microspheric forms (Fig. 18C, H) show a nepionic stage with a diameter of about $150 \mu \mathrm{m}$. In both generations, the ephebic stage consists of chambers planispirally arranged subdivided into chamberlets by septula, which alternate in successive chambers. The maximum equatorial diameter is around $1.6 \mathrm{~mm}$ for 7 whorls. The elongation index is about 1 .

Distribution. This species is present in Se/Th-1 DS of the Serraduy section (Fig. 4), Campo section (Fig. 5), Tena section (Fig. 6), Andia section (Fig. 9), Lizarraga section (Fig. 10), Urbasa Pass section (Fig. 11), Leortza section (Fig. 12) and Aixola-Ermua section (Fig. 14) with the species assemblage indicated in the aforementioned figures. In this latter section samples Er 1 and Er 2 were found in clasts of the calcareous breccia located in TH-2 DS.

Biozone. According to Hottinger (1960) and Serra-Kiel et al. (1998) this species is a biostratigraphic marker of the SBZ 3.

\section{Glomalveolina levis HOTTINGER, 1960}

\section{Fig. 18.9-18.12}

1960 Alveolina (Glomalveolina) levis. Hottinger, p. 55-57, text fig. $29 \mathrm{n}^{\circ} 28$; pl. 11-14

1974 Alveolina (Glomalveolina) levis HotTINGER, p. 35; Pl. 31, figs. 1-4

Material. Sample Se 2 from Serraduy section (Fig. 4); sample Cm 10 from Campo section (Fig. 5); sample Te 6 from Tena section (Fig. 6) and samples K 1 and K 2 from Korres section (Fig. 13).

Description. The test is porcelaneous with ovoidfusiform morphology. The megalospheric form shows an embryonic stage composed of a proloculus with a diameter of about $85 \mu \mathrm{m}$ followed by a flexostyle, the nepionic stage of 2-3 streptospiral whorls and a diameter of about $150 \mu \mathrm{m}$ (Fig. 18I). The possible microspheric forms (Fig. 18K) differ from the megalospheric form in possessing a tighter and smaller nepionic stage. In both generations, the ephebic stage consists of 7-8 whorls with planispiral chamber arrangement. The chamber lumen of the ephebic stage is subdivided into chamberlets by septula. Septula alternate in position in successive chambers. The elongation index is $1.3-1.7$.

Distribution. This species is identified in Th-2 DS in the Serraduy section (Fig. 4), Campo section (Fig. 5), Tena section and in Korres section (Fig. 13) with the species assemblage indicated in the aforementioned figures.

Biozone. According to Hottinger (1960) and SerraKiel et al. (1998) this species is a biostratigraphic marker of the upper Thanetian or SBZ 4.

\section{Genus Alveolina d'ORBIGNY}

Type species: Oryzaria boscii DEFRANCE, in BRONN

\section{Alveolina korresensis n. sp. Serra-Kiel and Vicedo Fig. 18M-Q}

Derivation of name. The specific name refers to the village of Korres.

Holotype. specimen illustrated in Figure 18M. Housed in the palaeontological collections of the Museu de Ciències Naturals de Barcelona, accession number MGB 89844 LP01.01.

Paratype. specimen illustrated in Figure 180. Housed in the palaeontological collections of the Museu de Ciències Naturals de Barcelona, accession number MGB 89844 LP01.02.

Type locality. Located in the Korres section, near the village of Korres. Sample K 2. Coordinates: N $42^{\circ} 51^{\text {' }}$ 54.54"/W 20 26' 13.62". 

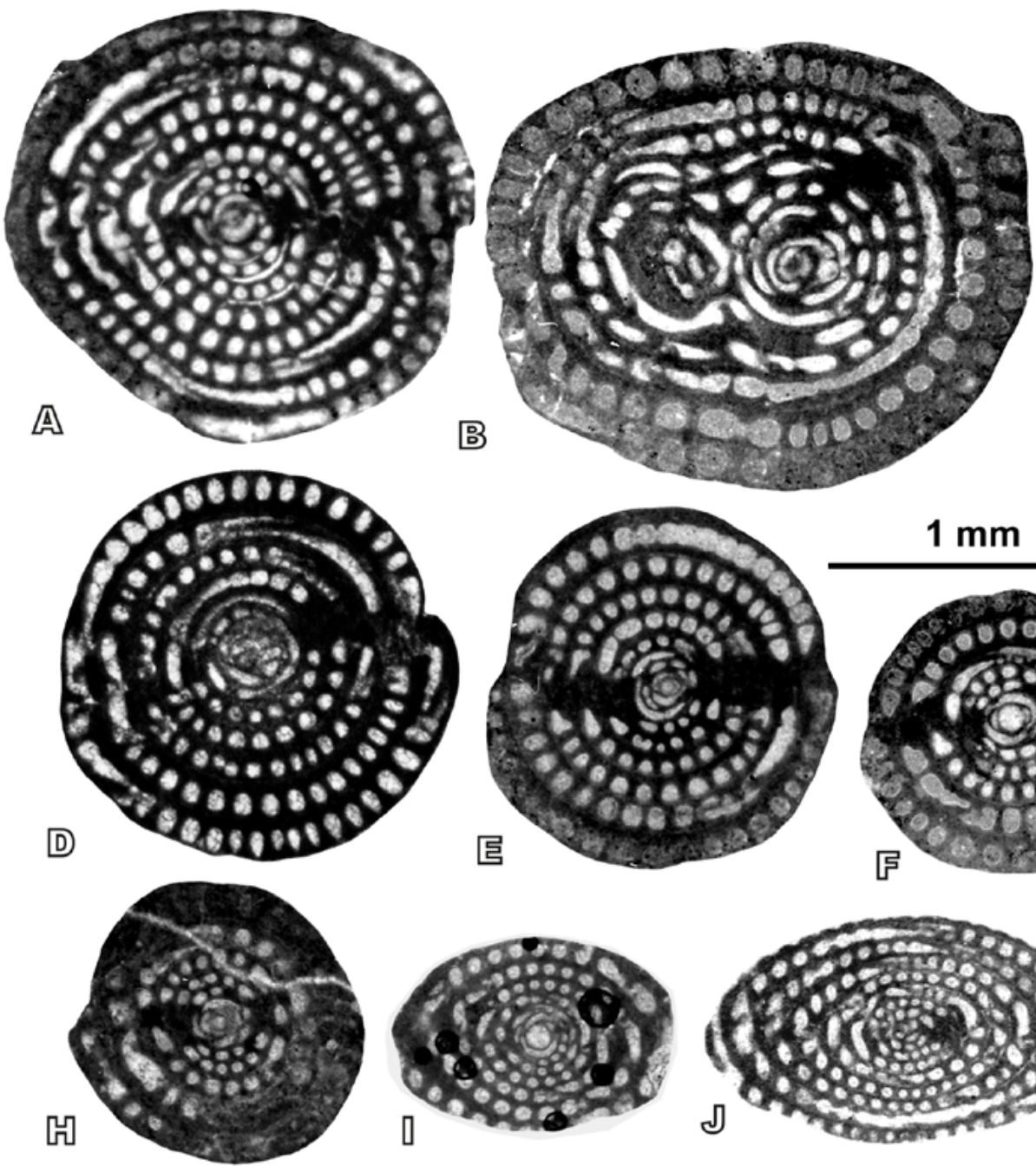

$1 \mathrm{~mm}$
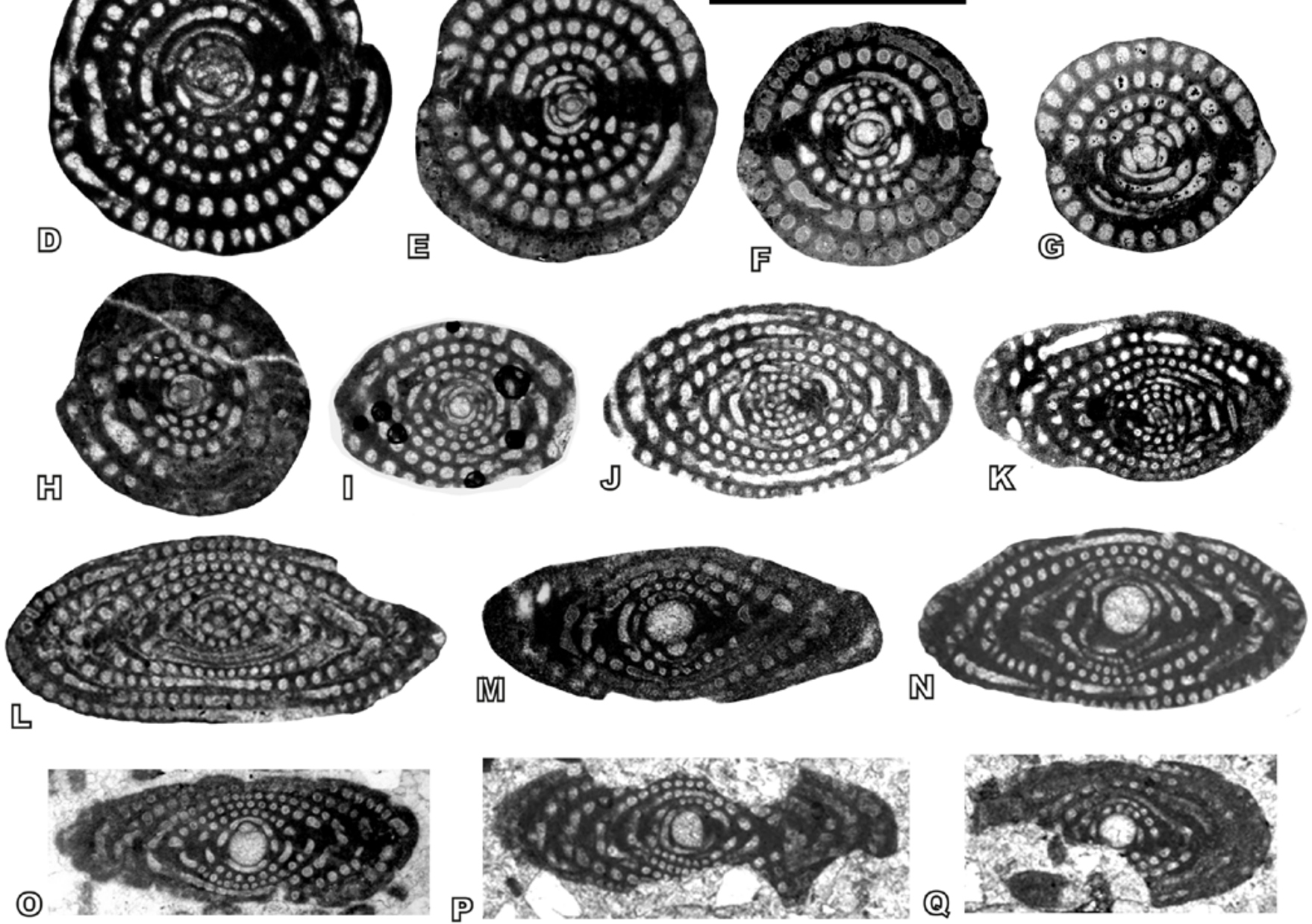

FIGURE 18. Paleocene Larger Foraminifera from the Pyrenean Basin. A-H: Glomalveolina primaeva (REICHEL, 1937) A and D megalospheric forms, uncentered axial sections; B polyvalent specimens; F-G centered axial sections; $\mathbf{C}$ uncentered possible microspheric form; $\mathbf{E}$ and $\mathbf{H}$ centered possible microspheric form. Specimens A, B, C and E from sample $\mathrm{Cm} \mathrm{8;} \mathrm{D,} \mathrm{F} \mathrm{and} \mathrm{G} \mathrm{from} \mathrm{sample} \mathrm{Le} 8$ and H from sample Urb 31. I-L: Glomalveolina levis HOTTINGER, 19609 centered axial section, megalospheric form; $\mathbf{J}, \mathbf{K}$ and $\mathbf{L}$ megalospheric forms, uncentered axial sections. All specimens from sample K 2. M-Q: Alveolina korresensis n. sp. centered axial sections of megalospheric forms M Holotype, O Paratype. All specimens from sample $\mathrm{K} 3$. 
Type level. “Assilina beds”, upper Thanetian or SBZ 4.

Material. Sample K 2 from the Korres section (Fig. 18M).

Diagnosis. Porcelaneous test, axially elongated morphology with rounded poles. Multiple apertures. Microspheric forms not found. Megalospheric form with a nepionic stage that consists of a proloculus of circular outline in axial section and a diameter of 140-190 $\mu \mathrm{m}$ followed by a flexostyle. Nepionic stage composed of 2 tight whorls, ephebic stage formed by 5 whorls. Maximum axial and equatorial diameters observed of $1.3-1.6 \mathrm{~mm}$ and 0.5-07mm respectively, with an elongation index of 2.0-2.1. Chamberlets in the nepionic stage showing a subrectangular outline in axial section becoming oval to subrectangular in ephebic whorls. Endoskeleton consisting of a thin basal layer and septula subdividing chambers into chamberlets. Septula alternating position in successive chambers.

Remarks. This species is the oldest representative of the genus Alveolina in the Paleocene from the Pyrenean basin. It differs from $A$. vredenburgi DAVIES AND PINFOLD, 1937 (=ex A. cucumiformis) in the smaller size of the test and in the thickness of the basal layer.

Distribution. This species is present in Th-2 DS in the Korres section (Fig. 13) with the species assemblage indicated in the aforementioned figure.

Biozone. According to the foraminiferal assemblage, $A$. korresensis can be considered as belonging to the SBZ 4 .

Class GLOBOTHALAMEA PAWLOWSKI et al., Order "TEXTULARIIDA" (DELAGE AND HЙROUARD partim

Superfamily Eggerelloidea CUSHMAN

Family Valvulinidaea BERTHELIN

Subfamily Valvulininaea BERTHELIN

Genus Goesella CUSHMAN

Type species: Clavulina rotundata CUSHMAN

\section{Goesella sp. \\ Fig. 19A-E}

2001 Goesella sp. Ogorelec et al., pl. 10, fig. 6

Material. Sample Urb 20 from Urbasa Pass section (Fig. 11); sample Abau 1 from Abaurrea section (Robador, 2005, Annex, p. 50-51) and sample Bin 3 from Foz de Biniés section (Robador, 2005, Annex, p. 90-91).

Description. The specimens show a finely agglutinated test of small size. The embryo consists of an ovoidal proloculus with a maximum diameter of around $135-120 \mu \mathrm{m}$ and minimum of around $80-110 \mu \mathrm{m}$. The neanic stage is composed of biserial chambers followed by the ephebic stage characterized by chambers arranged uniserially.

Distribution. This species has been identified in the DS Da-2 of the Urbasa Pass section (Fig. 11) and in samples from the lower part of the sections of Abaurrea and Foz de Biniés (see Robador, 2005). It is associated with species without biostratigraphical interest such as Lenticulina sp. and Robulus sp.

Biozone. Ogorelec et al. (2001) consider that this species belongs to the SBZ 2. This zonal assignment is in accordance with the data obtained in the Urbasa Pass section (Fig. 11). Its occurrence in the lower levels of the sections of Abaurrea and Foz de Biniés studied by Robador (2005) indicates that this species could also be present in SBZ 1.

\section{Superfamily Coscinophragmatoidea THWLMANN Family Haddoniidae CHAPMAN GENUS Haddonia CHAPMAN \\ Type species: Haddonia torresiensis, CHAPMAN}

Haddonia praeheissigi SAMUEL, KOHLER AND BORZA, 1977

Fig. 19F

1972 Haddonia sp. Samuel et al., pl. 2, figs. 1-2; pl. 3, figs. 1-2

1977 Haddonia praeheissigi n. sp., Samuel et al. pl. 48, figs. 1, 2; pl. 49, figs.1, 2; pl. 50. figs. 1, 2

1988 Haddonia sp., Drobne et al., pl. 26, fig. 5

2008 Haddonia praeheissigi SAMUEL, KÖHLER AND BORZA. Pignatti et al., pl. 7, fig. 5

2010 Haddonia praeheissigi SAMUEL, KÖHLER AND BORZA. Di Carlo et al., p. 50-51; pl. 1, fig. 1; pl. 3, figs. $1-2$

Material. Samples L 8 and L 9 from Lizarraga section (Fig. 10); samples Urb 2, Urb 4, Urb 6, Urb 7, Urb 13, Urb 25, Urb 27 and Urb 28 from Urbasa Pass section (Fig. 11); sample Le 2 from Leortza section (Fig. 12) and samples Aix 5 and Er 5 from Aixola-Ermua section (Fig. 14).

Description. The wall is composed of two layers, the external layer consists of coarsely agglutinated particles, mainly of quartz, calcareous cement, and a thin inner layer formed of micrite, which is poorly preserved in the material studied. The morphology is irregular, showing protuberances on the external surface. Chambers are also irregular in shape.

Distribution and age. The morphology of this species suggests that it lived attached to the substrate, probably 

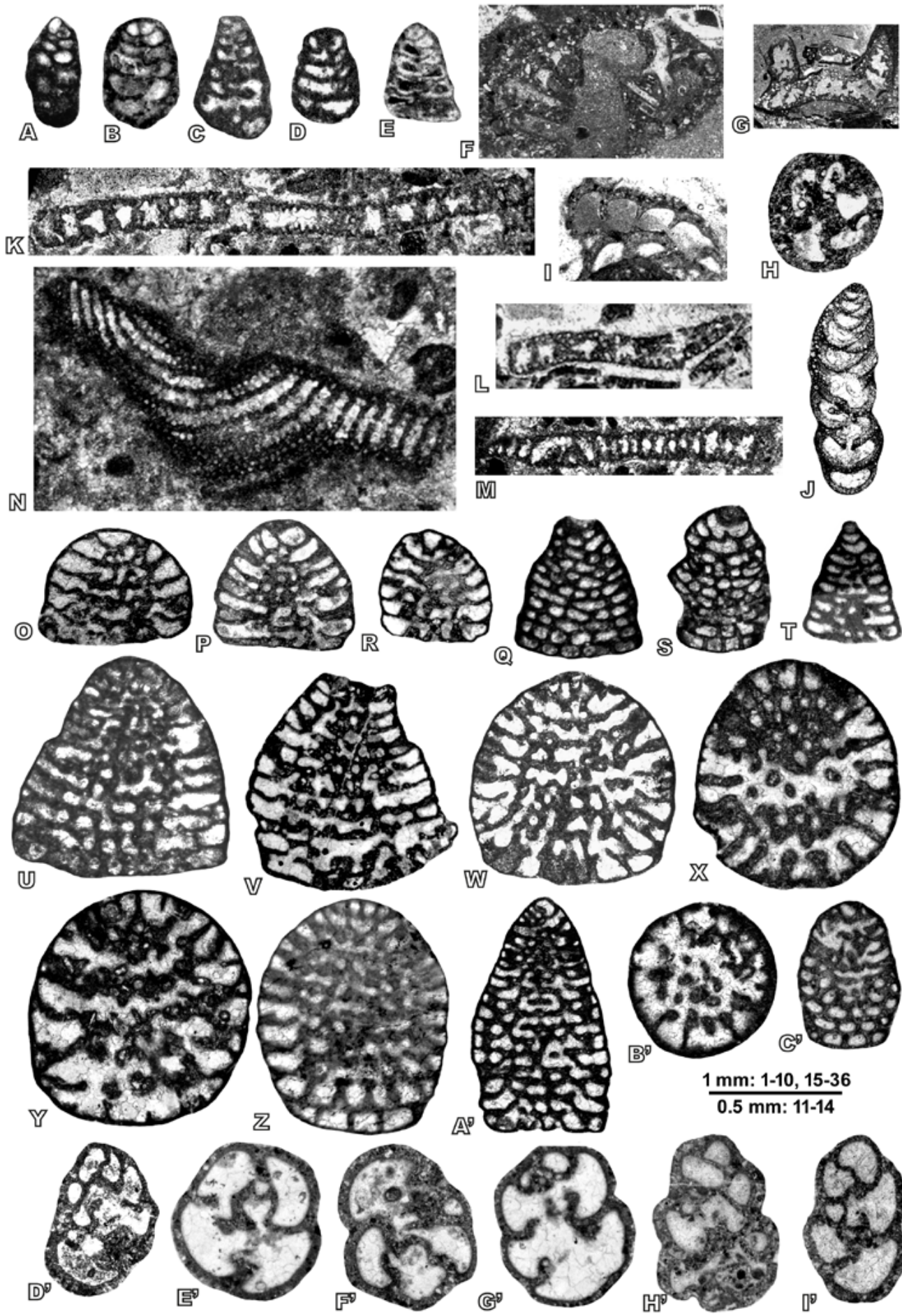

FIGURE 19. Paleocene Larger Foraminifera from the Pyrenean Basin. A-E: Goesella sp. Iongitudinal sections. Specimens A, B and E from sample Abau 1; C from sample Bin 3 and D from sample Urb 20. F: Haddonia praeheissigi, samuEl et al., 1977 specimen from sample Er 5. G: Coscinophragma cribosum (REUSS, 1846) specimen from sample Lech 12. H: Kolchidina cf. paleocenica (cusHMAN, 1947) uncentered longitudinal section, specimen from sample Bur 3. I: Placopsilina cenomana d'orbigny, 1850 specimen from sample Le 2. J: Popovia cf. plana (вүкоVA, 1939) equatorial section, specimen from sample Orio 3. K-N: Vania anatolica SIREL AND GüNDüz, 1985. K-M uncentered axial sections; N equatorial section; Specimens K and $\mathrm{M}$ from sample $\mathrm{Cm}$ 5; L from sample $\mathrm{Cm} 7$ and $\mathrm{N}$ from sample Le 8. 0-T: Coskinon rajkae (HOTTINGER AND DROBNE, 1980) $\mathbf{0}$ oblique-basal section; $\mathbf{P}$ section parallel and close to axis; $\mathbf{Q}$ oblique section close to axial plane; $\mathbf{R}-\mathbf{T}$ axial sections. Specimen $\mathrm{O}$ from sample Te 4; P from sample $\mathrm{Cm}$ 5; $\mathbf{Q}$ from sample Cm 8; R and S from sample Le 8 and T from sample Bur 7. U-C': Fallotella alavensis mangin, 1954. U, V and A' longitudinal sections parallel to axial plane; $\mathbf{W}$ and $\mathbf{Y}$ oblique basal sections; $\mathbf{X}$ and $\mathbf{B}^{\prime}$ basal sections; $\mathbf{Z}$ oblique section; $\mathbf{C}^{\prime}$ longitudinal oblique section. Specimens $U$ and A' from sample Le 5; V from sample Cm 8; W, Y and Z from sample Le 8; X and B' from sample Le 7 and C' from sample Bur 7. D'-l': Cribrobulimina carniolica HOtTINGER AND DROBNE, 1980. D', H' and l' no centered sections parallel to axis; E' basal section showing the foramina in the septum; F' and G' oblique sections. Specimens D', and G' from sample Cm 5; E', F' and H' from sample Cm 8 and I' from sample Coll 3. 
to "seagrasses" and substrates from reef environments developed in the inner shelf. It has no biostratigraphic significance.

Family: Coscinophragmatidae THALMANN

GENUS Coscinophragma THALMANN

Type species: Lichenopora cribosa, REUSS

\section{Coscinophragma cribosum (REUSS, 1846) Fig. 19G}

1972 Coscinophragma cribosum (REUSS, 1846). Samuel et al., pl. 4, fig. 1-2; pl. 5, fig. 1

Material. Sample Lech 12 from Lecherín section (Robador, 2005, Annex, p. 24-25).

Description. The shell is agglutinated, flattenedirregular in shape, with branches. The ephebic stage shows chambers in uniserial distribution. The wall is composed of three layers: the outer part consisting of a homogeneous calcareous layer, the inner layer composed of large quartz grains and the median layer is pierced by canaliculi perpendicular to the surface of the test. The apertures are cribrate.

Distribution and age. The morphology of this species suggests that it lived attached to the substrate, probably on the "seagrass" and on otherv substrates of reef environments of the inner shelf. It has no biostratigraphic significance.

\section{Superfamily: Lituoloidea DE BLAINVILLE \\ Family: Lituolidae DE BLAINVILLE \\ Subfamily: Lituolinae DE BLAINVILLE \\ GENUS Kolchidina, MOROzOVA}

Type species: Ammobaculites manyschensis, BYKOVA

\section{Kolchidina cf. paleocenica (CUSHMAN, 1947) Fig. 19H}

1998 Kolchidina paleocenica (CUSHMAN). Sirel, p. 35 365; pl. 1, fig. 19-24

2009 Kolchidina paleocenica (CUSHMAN). Sirel, pl. 2, figs. 15-16

2015 Kolchidina paleocenica (CUSHMAN). Sirel, pl. 4 figs. 1-6

2018 Kolchidina paleocenica (CUSHMAN). Sirel, pl. 48, figs. 1-6

Material. Sample Bur 3 collected by Robador from Burgi section (Robador, 2005, Annex, pp. 78-79).

Description. The test is coarsely agglutinated with a thick wall. The nepionic stage consists of a proloculus followed by planispirally arranged chambers. The ephebic stage, consisting of uniserially arranged chambers, is not present in the single specimens found.

Remarks. The specific determination of this taxon has been left open since the ephebic stage could not be observed.

Distribution. In the material studied $K$. cf. paleocenica is associated with $M$. minutus and T. madrugaensis.

Biozone. According to Sirel (1998) this species occurs in the Danian from Turkey. These data and the results presented here indicate that its biostratigraphic range is within SBZ 3.

Family: Placopsilinidae RHUMBLER

Subfamily: Placopsilininae RHUMBLER

GENUS Placopsilina D'ORBIGNY

Type species: Placopsilina cenomana, D'ORBIGNY

\section{Placopsilina cenomana D'ORBIGNY, 1850 \\ Fig. 19I}

1972 Placopsilina cenomana D'ORBIGNY. Samuel et al., pl. 1, fig. 1-2

Material. Samples Urb 2 and Urb 3 from Urbasa Pass section (Fig. 11) and sample Le 2 from Leortza section (Fig. 12).

Description. The test is flattened with irregular morphology. Wall thick and formed of coarse agglutinated particles. Each chamber overlaps the previous, forming a relief on the surface of the test. The apertures are located in the base of the septum and with a slight lip. The septal sutures are well-marked.

Distribution. The morphology of this species suggests that this species lived attached to the substrate, probably on the "seagrass" and on other substrates from reef environments of the inner shelf. This species is found in Ma-Da DS from Urbasa Pass section and in Se/Th-1 DS from Leortza section.

Biozone. According to the data presented herein, the biostratigraphic range of this species is from SBZ 1 to SBZ 3.

Superfamily: Loftusioidea BRADY

Family: Cyclamminidae MARIE

Subfamily: Alveolophragmiinae SAIDOVA

GENUS Popovia, SULEYMANOV

Type species: Alveolophragmium planum, BҮКОVA 
Popovia cf. plana (BYKOVA, 1939)

Fig.19J

1998 Popovia plana (вҮкоVA). Sirel, p. 37-38; pl. 35, figs. 37-38

2004 Popovia sp., Sirel, pl. 9, figs. 18-19

2015 Popovia plana (BYKOVA). Sirel, pl. 5, figs. 13-14

Material. Sample Orio 3 from a pebble taken from Orio section (p. 248, fig. 75, Baceta, 1996).

Description. The wall is agglutinated, thick with an alveolar texture. The apertures in nepionic stage are interiomarginal in position. The ephebic chambers have a uniserial arrangement.

Remarks. The specific identification of this species has been left in open nomenclature since the nepionic stage could not been observed.

Distribution. This species has been found associated with M. minutus and T. madrugaensis.

Biozone. According to Sirel (1998) this species occurs in the Thanetian from Turkey associated with $G$. primaeva, $F$. kochanskae and I. sinjarica. These data and the results presented here indicate that its biostratigraphic range is SBZ 3.

Family: Spirocyclinidae MUNIER-CHALMAS

GENUS Vania SIREL AND GbNDbZ

Type species: Vania anatolica SIREL AND GbNDbZ

\section{Vania anatolica SIREL AND GbNDbZ, 1985}

Fig. 19K-N

1971 Broeckinella arabica HENSON. Drobne and Hottinger, p. 9, text fig. 2d, e; 3a-d; pl. 3, 4

1978 Broeckinella arabica HENSON. Rahaghi, p. 39; pl. 1, fig. 1, 2

1985 Vania anatolica Sirel and Gündüz, p. 20-24; text fig. 2A, B; pl. 1 fig. 1-3, pl. 2, fig. 1-6, pl. 3, fig. 1-7

1989 Broeckinella arabica HENSON. Kuss and Leppig, p. 312 , fig. $5 \mathrm{k}$

1998 Vania anatolica SIREL AND GÜNDÜZ. Sirel, p. 4344, pl. 6, fig. 9-14

2004 Vania anatolica SIREL AND GÜNDÜZ. Sirel, p. 2224; pl. 24, figs. 1-3; pl. 25, figs. 1-6; pl. figs. 1-7; textfig. $10 \mathrm{~A}, \mathrm{~B}$

2008 Vania anatolica SIREL AND GÜNDÜZ. Pignatti et al., pl. 7, figs. 3-4

2010 Vania anatolica SIREL AND GÜNDÜZ. Di Carlo et al., p. 51 ; pl. 3 , figs. $3-7^{\text {a }}, 8$

2012 Vania anatolica SIREL AND GÜNDÜZ. Sirel, pl. 8, figs. 10-15
2015 Vania anatolica SIREL AND GÜNDÜZ. Sirel, pl. 27, figs. 10-15 and pl. 50, figs. 10-15

Material. Samples $\mathrm{Cm} 3, \mathrm{Cm} 5$ and $\mathrm{Cm} 7$ from Campo section (Fig. 5); sample Te 4 from Tena section (Fig. 6); sample G 3 from Garralda section (Fig. 7); sample An 10 from Andia section (Fig. 9) and samples Le 3, Le 6, Le 7 and Le 8 from Leortza section (Fig. 12).

Description. The test is agglutinated with discoidal morphology. In the material studied, the embryonic and nepionic stages could not be observed. The chambers of the ephebic stage are annular. The exoskeleton consists of beams and rafters, forming a polygonal network. Foramina are arranged in rows with radial axes in successive chambers.

Distribution. This species is found in the Se/Th-1 DS of the Campo section (Fig. 5), Tena section (Fig. 6), Garralda section (Fig. 7), Andia section (Fig. 9) and Leortza section (Fig. 12) with the species assemblage indicated in the aforementioned figures.

Biozone. According to Sirel (1998) this species occurs in the Thanetian associated with $G$. primaeva, $G$. dachelensis, M. juliettae, C. rajkae and I. sinjarica. Later, Serra-Kiel et al. (1998) considered this species as belonging to SBZ 3, from which it can be considered a marker.

\section{Superfamily Ataxophragmioidea SCHWAGER Family Coskinolinidae MOULLADE \\ GENUS Coskinon HOTTINGER AND DROBNE Type species: Coskinolina (Coskinolina) rajkae, HOTTINGER AND DROBNE}

\section{Coskinon rajkae (HOTTINGER AND DROBNE, 1980) Fig. 190-T}

1980 Coskinolina (Coskinon) rajkae. Hottinger and Drobne, p. 45-46, text fig. 2; pl. 2, fig. 2-4; pl. 12. figs. $1-28$

1988 Coskinon rajkae (HOTTINGER AND DROBNE). Drobne et al., pl. 26, fig. 7, 8

1998 Coskinolina (Coskinon) rajkae (HOTTINGER AND DROBNE). Sirel, p. 47, pl. 9, fig. 6-10

2001 Coskinon rajkae (HOTTINGER AND DROBNE). Ogorelec et al., pl. 10, fig. 7

2001 Coskinon rajkae (HOTTINGER AND DROBNE). Özgen and Akyazi, pl. 1, fig. 9-11

2008 Coskinon rajkae (HOTTINGER AND DROBNE). Pignatti et al., pl. 7, figs. 6, 9b

2010 Coskinon rajkae (HOTTINGER AND DROBNE). Di Carlo et al., p. 51-52; pl. 3, figs. 10, 11, 13; pl. 5, fig. $25 \mathrm{~A}$

2013 Coskinon rajkae (HOTTINGER AND DROBNE). 
Sirel, p. 34, pl. 5, figs. 1-5

2015 Coskinon rajkae (HOTTINGER AND DROBNE). Sirel, p. 28, figs. 1-5

2018 Coskinon rajkae (HOTTINGER AND DROBNE). Sirel, p. 56, figs. 1-5

Material. Samples Cm 5, Cm 7 and $\mathrm{Cm} 8$ from Campo section (Fig. 5); samples Te 4 and Te 5 from Tena section (Fig. 6); sample An 6 from Andia section (Fig. 9); sample L 26 from Lizarraga Section (Fig. 10); samples Le 5, Le 7 and Le 8 from Leortza section (Fig. 12) and sample Bur 7 from Burgi section (Robador, 2005, Annex, p. 76-77).

Description. The test is agglutinated with high-conical morphology and cribrate aperture. The wall is thick and displays a pseudokeriothecal texture. The embryo could not be adequately observed. It is followed by chambers with trochospiral arrangement. The ephebic stage is composed of 8-10 chambers arranged uniserially. The apertural face is convex in early growth stages, becoming slightly convex or flat in the ephebic stage. The endoskeleton is composed of pillars arranged discontinuously from one chamber to the next. At a cone diameter of $0.9 \mathrm{~mm}$, the axial length is $1.2 \mathrm{~mm}$. The axial plane cuts 5-6 pillars in adult chambers. Chamber sutures are slightly depressed.

Distribution. This species is present in the Se/Th-1 DS of the Campo section (Fig. 5), Tena section (Fig. 6), Andia section (Fig. 9), Lizarraga section (Fig. 10) and in Leortza section (Fig. 12), with the species assemblage indicated in the aforementioned figures.

Biozone. Hottinger and Drobne (1980), Drobne et al., (1988), Sirel (1998), Ogorelec et al. (2001) and Özgen and Akyazi (2001) reported this species as belonging to the Glomalveolina primaeva Zone. This species can be considered as a marker of the SBZ 3.

\section{Superfamily Orbitolinoidea MARTIN \\ Family Orbitolinidae MARTIN \\ Subfamily Dictyoconinae MOULLADE \\ GENUS Fallotella MANGIN}

Type species: Fallotella alavensis MANGIN

\section{Fallotella alavensis MANGIN, 1954 \\ Fig. 19U-C'}

1954 Fallotella alavensis sp., MANGIN, p. 209; text figs. 1-3; pl. 3, figs. 1-6

1980 Fallotella (Fallotella) alavensis MANGIN. Hottinger and Drobne, p. 50-51, pl. 14, fig. 1-27

1983 Fallotella alavensis MANGIN. Rahaghi, p. 28-29, pl. 2, fig. 1-5

2001 Fallotella alavensis MANGIN. Özgen and Akyazi, pl. 1, fig. 4-6
2008 Fallotella alavensis MANGIN. Pignatti et al., pl. 5, fig. 2; pl. 7, figs. 2, 7a

2010 Fallotella alavensis MANGIN. Di Carlo et al., p. 52; pl. 3, figs. 14-22

Material. Samples $\mathrm{Cm} 3$ and $\mathrm{Cm} 8$ from Campo section (Fig. 5); samples Te 3, Te 4 and Te 5 from Tena section (Fig. 6); samples Le 5, Le 7 and Le 8 from Leortza section (Fig. 12); samples Aix 19 and Aix 20 from AixolaErmua section (Fig. 14) and sample Bur 7 from Burgi section (Robador, 2005, Annex, p. 76-77).

Description. The test is agglutinated with high-conical morphology. The cone surface is smooth. The wall is thin without ultrastructure. The maximum cone-length observed is around $1.8 \mathrm{~mm}$ with $15-16$ uniserial chambers. The maximum diameter measured of an adult chamber is around $1.7 \mathrm{~mm}$. The embryonic stage has not been adequately observed. The nepionic stage is composed of chambers in trochospiral arrangement. The neanic stage consists of chambers arranged uniserially. There are 10-12 chambers per millimetre of axial length. The exoskeleton appears first in the neanic stage and consists of beams. The endoskeleton is composed of pillars with a subcircular horizontal section, except below the ceiling of the chamber where pillars have an elliptical shape in transverse section. Pillars alternate in position from one chamber to the next. The apertural face is slightly convex, and the aperture is cribrate.

Distribution. This species is present in the $\mathrm{Se} / \mathrm{Th}-1$ DS of the Campo section (Fig. 5), Tena section (Fig. 6), Leortza section (Fig. 12) and in Aixola-Ermua section (Fig. 14) with the species assemblage indicated in the aforementioned figures.

Biozone. This species was described by Mangin (1954) in the Paleocene from the Pyrenean basin. Later, Hottinger and Drobne (1980) and Serra-Kiel in Robador et al. (1991a, b) found it associated with $G$. primaeva, $C$. rajkae and $V$. anatolica, pointing it as a marker of the SBZ 3.

\section{Superfamily: Eggerelloidea CUSHMAN \\ Family: Valvulinidae BERTHELIN \\ Subfamily: Valvulininae BERTHELIN \\ GENUS Cribrobulimina CUSHMAN}

Type species: Valvulina mixta PARKER AND JONES

\section{Cribrobulimina carniolica HOTTINGER AND DROBNE, 1980}

Fig. 19D'-I'

1980 Cribrobulimina carniolica, Hottinger and Drobne, p. 219-221; pl. 3, fig. 1-11; pl. 2, fig. 1, 3

1988 Cribrobulimina carniolica HOTTINGER AND DROBNE. Drobne et al., pl. 26, fig. 10-11 
2001 Cribrobulimina carniolica HOTTINGER AND DROBNE. Özgen and Akyazi, pl. 1, fig. 7, 8

2010 Cribrobulimina aff. carniolica HOTTINGER AND DROBNE, 1980. Di Carlo et al., p. 53; pl. 3, figs. 9, 12

Material. Sample Se 1 from Serraduy section (Fig. 4); samples Cm 5 and Cm 8 from Campo section (Fig. 5); samples Te 3, Te 4 and Te 5 from Tena section (Fig. 6); samples Le 6, Le 7 and Le 8 from Leortza section (Fig. 12) and sample Coll 3 from Collarada section (Robador, 2005, Annex, p. 22-23).

Description. The test is agglutinated with low-conical morphology. The wall is thick with pseudokeriothekal texture. Chambers are inflated and arranged trochospirally. The sutures are strongly depressed. The apertures are interiomarginal in position in the early stage of growth, later becoming cribrate with multiple large apertures.

Distribution. This species is present in Se/Th-1 DS in the Serraduy section (Fig. 4), Campo section (Fig. 5), Tena section (Fig. 6) and Leortza section (Fig. 12) with the species assemblage indicated in the aforementioned figures.

Biozone. Hottinger and Drobne (1980) identified this species in Thanetian rocks associated to $G$. primaeva, $F$. alavensis, $C$. rajkae and $V$. anatolica (=ex Broeckinella arabica). Later, Serra-Kiel et al., (1998) considered it as a marker of the SBZ 3.

\section{Order: Rotaliida (DELAGE AND HЙROUARD) Superfamily: Rotalioidea EHRENBERG Family: Elphidiidae GALLOWAY GENUS Bangiana DROBNE, OGORELEC AND RICCAMBONI}

Type species: Bangiana hanseni DROBNE, OGORELEC AND RICCAMBONI

\section{Bangiana hanseni DROBNE, OGORELEC AND RICCAMBONI, 2007 \\ Fig. 20A-O}

1988 Protelphidium sp. Drobne et al., pl. 25, figs. 8-11 2001 Bangiana hanseni. Ogorolec et al., pl. 9, figs. $16-20$

2007 Bangiana hanseni. Drobne et al., p. 16-24; pls. $1-12$

Material. Sample Te 1 from Tena section (Fig. 6); samples Urrob 1 and Urrob 2 from Urrobi section (Fig. 8) and samples Urb 12, Urb 16 and Urb 21 from Urbasa Pass section (Fig. 11).

Description. The lamellar-perforated test is small, biumbilical, depressed with a planispiral involute chamber arrangement. The wall is thin. The chambers are inflated increasing in size through ontogeny. The apertures are located at the base of the apertural face.

Distribution. This species is present in the Da-1 DS from Tena section (Fig. 6). Da-2 DS from Urbasa Pass section (Fig. 11) associated with $H$. paleocenica, $H$. elongata and Goesella sp. and overlaying M. globularis and $O$. moorkensii. Finally, this species is also present in DA-1 DS and DA-2 DS from Urrobi section (Fig. 8).

Biozone. Drobne et al. (1988), Serra-Kiel et al. (1998) and Drobne et al. (2007) considered this species as a marker of the SBZ 1. However, in the material studied it is associated with foraminifera of SBZ 2. Consequently, its range should be extended to this latter biozone.

\section{Family: Rotaliidae EHRENBERG \\ Subfamily: Rotaliinae EHRENBERG \\ GENUS Rotorbinella BANDY \\ Type species: Rotorbinella colliculus BANDY}

\author{
Rotorbinella hensoni (SMOUT, 1954) \\ Fig. 20P-S
}

1954 Rotalia hensoni. Smout, p. 45; pl. 15, fig. 8

1973 Discorbis perovalis (TERQUEM). Ferrer et al., p. 38; pl. 37, figs. 1, 3

2006 Rotorbinella sp. HOTTINGER, p. 86; pl. 2, figs. 1116

2014 Rotorbinella hensoni (SMOUT, 1954). Hottinger, p. 24; Figs. 3.2, 3.3A-F; pl. 3.2, figs. 1-13

2014 Rotorbinella detrecta. Hottinger, p. 26, pl. 3.4A$\mathrm{H}$

Material. Sample An 8 from Andia section (Fig. 9); samples Urb 5, Urb 6 and Urb 9 from Urbasa Pass section (Fig. 11) and samples Ur 8, Ur 10, Ur 11, Ur 16 and Ur 17 from Urko section (Fig. 15).

Description. Small size, bilamellar-perforate test. The morphology is low-trochospiral with a rounded periphery. The ventral and dorsal sides have high convexity. The umbo is pronounced with a massive plug. The diameter of the proloculus is small (about $20 \mu \mathrm{m}$ ). The diameter of the shell with 2 whorls is about $0.58 \mathrm{~mm}$ and the height is $0.35 \mathrm{~mm}$.

Distribution. This species is present in the Da-1 DS from Urbasa Pass section (Fig. 10), and Urko section (Fig. 15), Da-2 DS from Urko section (Fig. 16), Se/Th-1 DS from Andia section (Fig. 9) with the species assemblage indicated in the aforementioned figures.

Biozone. According to Hottinger (2014) and Vicedo et al. (2019) its biostratigraphic range is SBZ 2 to SBZ 3. 


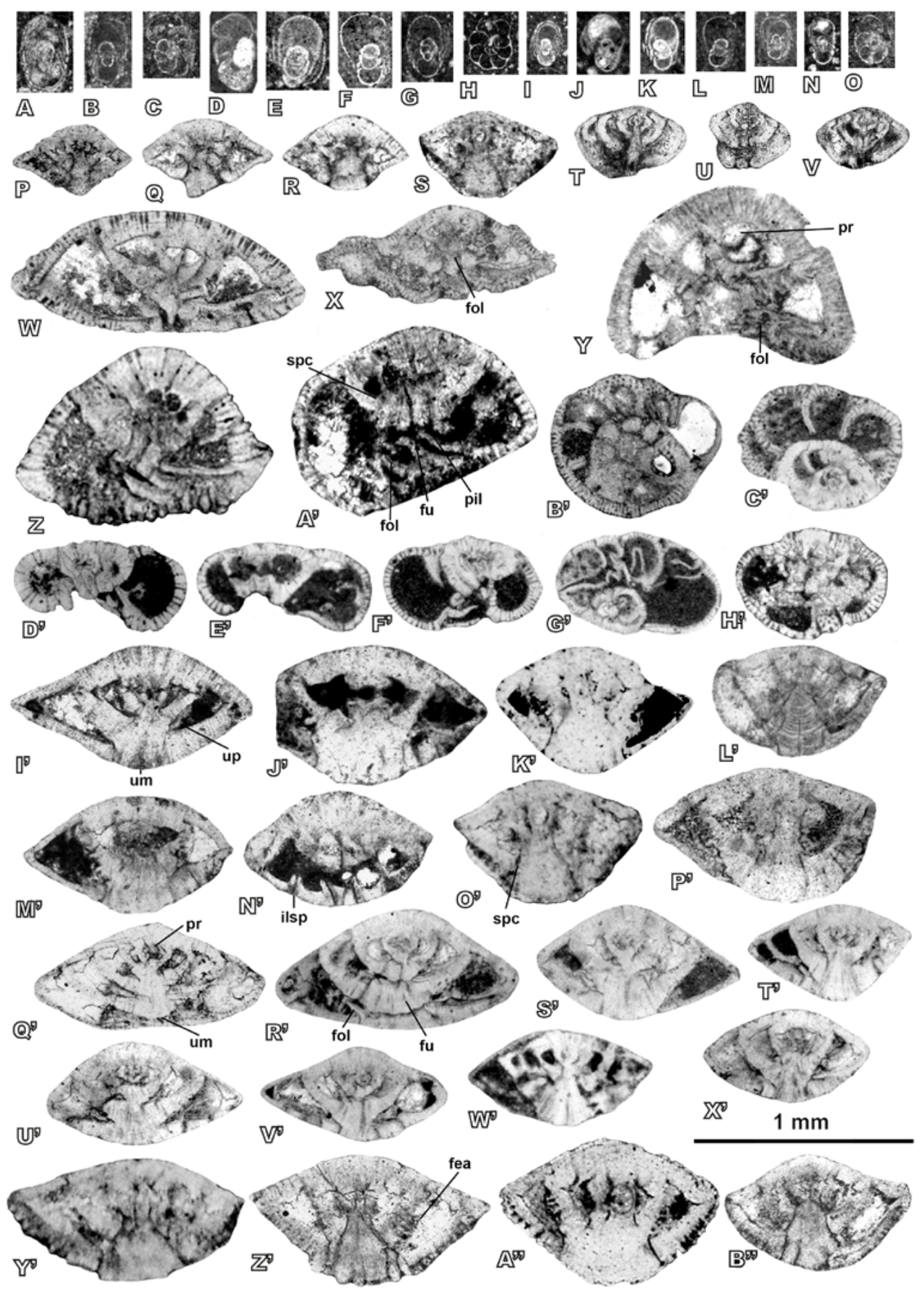

FIGURE 20. Paleocene Larger Foraminifera from the Pyrenean Basin. A-0: Bangiana hanseni drobne et al., 2007. A-B, E-G, I-0 and Q axial sections. C-D oblique sections; H-P equatorial sections. Specimens A, B, E and K from sample Urrob 1; C, D, F-I and L-O from sample Urb 12 and J from sample Te 1. P-S: Rotorbinella hensoni (smout, 1954) axial sections. Specimen P from sample Ur 8; Q from sample Ur 10; $R$ and S from sample An 8. T-V: Rotorbinella skourensis (PFENDER, 1938) axial sections. Specimens T, U from sample Ur 8 and V from sample Ur 10. W-X: Pyrenerotalia depressa HOTTINGER, 2014 slightly oblique axial sections. Specimens from sample Ur 8. Y-A': Rotospirella conica (smout, 1954). Y-Z adaxial sections. A' oblique section. Specimen Y from sample Salv 4 and Z and A' from sample L 3. B'-H': Redmondina henningtoni HASson, 1985. B'-C' no centered sections perpendicular to coiling axis. D'-F' adaxial sections. G' oblique section to coiling axis, Specimen B' from sample $\mathrm{K} 2$ and $\mathrm{C}^{\prime}-\mathrm{H}^{\prime}$ from sample Cm 8. I'-P': Kathina aquitanica HotTinger, 2014. I'-L' and O' centred axial section; M' and P' uncentered axial sections and N' oblique section. Specimens I', J', M', N' from sample An 10; K' from sample An 9; O' from sample Aix 19; P' from sample L 24 and L' from sample Cm 3. Q'-X': Kathina pernavuti sIREL, 1972 axial sections. Specimen Q' from sample Salv 5 and R'-X' from sample Cm 8. Y'-B": Elazigina dienii (HotTINGER, 2014) all specimens in axial sections. Specimens $Y^{\prime}-A^{\prime \prime}$ from sample Aix 9 and B" from sample $L$ 3. Abbreviations: pr: proloculus, um: umbilical umbo, up: umbilical plate, ilsp: intraseptal interlocular space, spc: spiral canal, fu: funnel, fea: feathering interlocular space, fol: folium, pil: pile, fol: folium, spsut: spiral suture. 
Rotorbinella skourensis (PFENDER, 1938) Fig. 20T-V

2009 Rotalia trochidiformis LAMARCK. Afzal et al., pl. 1, fig. 12

2014 Rotorbinella skourensis (PFENDER, 1938). Hottinger, p. 24; pl. 3.1, figs. 1-18

Material. Sample Cm 3 from Campo section (Fig. 5); sample L 26 from Lizarraga section (Fig. 10) and samples Ur 8 and Ur 10 from Urko section (Fig. 15).

Description. Bilamellar-perforate test. The morphology is low-trochospiral with rounded periphery. The ventral side has high convexity. The umbo is pronounced. The diameter of the proloculus is around $60 \mu \mathrm{m}$. The adult shell has a diameter of around $0.50 \mathrm{~mm}$ with 3 whorls and a height of $0.33 \mathrm{~mm}$.

Distribution. This species is present in the Da-1 DS from Urko section (Fig. 15), Se/Th-1 DS from Campo section (Fig. 5) and in Lizarraga section (Fig. 10) with the species assemblage indicated in the aforementioned figures.

Biozone. According to Hottinger (2014) R. skourensis belongs to the SBZ 3-SBZ 4. However, the presence of this species in the Da-1 DS in the Urko section (Fig. 14) implies that its biostratigraphic range ranges from SBZ 2 to SBZ 4.

\section{GENUS Pyrenerotalia BOIX, VILLALONGA, CAUS AND HOTTINGER \\ Type species: Pyrenerotalia longifolia BOIX, VILLALONGA, CAUS AND HOTTINGER}

\section{Pyrenerotalia depressa HOTTINGER, 2014 \\ Fig. 20W-X}

2014 Pyrenerotalia depressa. Hottinger, p. 26, 29-30; fig. 3.5A-I

Material. Sample Ur 8 from Urko section (Fig. 15).

Description. Test with coarsely perforated wall. The morphology is lenticular with a trochospiral chamber arrangement and rounded periphery. The folia overlap the adaxial part of the umbilicus (Fig. 20). The diameter for 3 whorls is around $1 \mathrm{~mm}$ and the height $0.45 \mathrm{~mm}$.

Distribution. This species has been identified in Urko section (Fig. 15) in Da-1 DS with the species assemblage indicated in the aforementioned figure.

Biozone. $P$. depressa was studied by Hottinger (2014) without specifying its biostratigraphic range. The association of $P$. depressa with $O$. moorkensii implies a biostratigraphic range equivalent to the SBZ 2.

\section{Subfamily: Praelockhartiinae VICEDO AND ROBLES- SALCEDO \\ GENUS Rotospirella HOTTINGER \\ Type species: Lockhartia conica, SMOUT}

\section{Rotospirella conica (SMOUT, 1954) \\ Fig. 20Y-A'}

1954 Lockhartia conica. SMOUT, p. 53; pl. 4, figs.1-3 1991 Lockhartia conica SMOUT. Wan, p. 162; pl. 1, figs. 28-29

2014 Rotospirella conica (SMOUT). HOTTINGER, p. 2931; fig. 3.4

Material. Sample L 3 from Lizarraga section (Fig. 10) and sample Salv 4 from Salvatierra de Esca section (Robador, 2005, Annex, p. 92-95).

Description. Test with coarsely perforated, bilamellar wall and conical morphology. The chambers are arranged trochospirally. The dorsal side is smooth without ornamentation; the chambers sutures flush. The ventral side is covered by long and delicate folia. Umbilicus composed of piles and funnels. The diameter of the proloculus is around $110 \mu \mathrm{m}$.

Distribution. This species has been identified in the Da-2 DS of the Lizarraga section (Fig. 10) with the species assemblage indicated in the aforementioned figure.

Biozone. The larger foraminifera associated to this species suggests a biostratigraphic range within SBZ 2.

\section{Subfamily: Redmondininae HOTTINGER GENUS Redmondina HASSON Type species: Redmondina henningtoni HASSON}

\section{Redmondina henningtoni HASSON, 1985} Fig. 20B'- $\mathrm{H}^{\prime}$

1985 Redmondina henningtoni. Hasson, p. pl. 4.1, figs. 1-19; pl. 4.2, figs. 1-13

2000 Redmondina henningtoni HASSON. Peybernès et al., p. 46, figs. 67 and 8

2014 Redmondina henningtoni HASSON. Hottinger, p. 41; pl. 4.1, figs 1-19; pl. 4.2, figs. 1-13

Material. Samples $\mathrm{Cm}$ 4, Cm 5 and $\mathrm{Cm} 8$ from Campo section (Fig. 5); sample Te 5 from Tena section (Fig. 7); samples Le 7 and Le 8 from Leortza section (Fig. 12) and $\mathrm{K} 2$ from Korres section (Fig. 13). 
Description. Bilamellar perforate shell with trochospiral chamber arrangement. The chamber wall shows coarse pores and rounded periphery. The umbilical filling is reduced with short and folded folia. The proloculus diameter is around $50 \mu \mathrm{m}$. The diameter of the shell varies from 0.70 to $0.80 \mathrm{~mm}$ with 3 whorls and the height from 0.40 to $0.50 \mathrm{~mm}$.

Distribution. This species is present in the Se/Th-1 DS from Campo section (Fig. 5); Tena section (Fig. 6) and in Leortza section (Fig. 12) and in the Th-2 DS from Korres section (Fig. 13) with the species assemblage indicated in the aforementioned figures.

Biozone. According Hottinger (2014) the biostratigraphic range of this species extends from SBZ 3 to SBZ 6.

\section{Subfamily: Kathininae HOTTINGER GENUS Kathina SMOUT Type species: Kathina delseota SMOUT}

\section{Kathina aquitanica HOTTINGER, 2014 \\ Fig. 20I'-P'}

1998 ?Kathina gr. pernavuti SIREL. Accordi et al., p. 200; pl. 16, fig. 2

2006 Kathina sp. Hottinger, p. 87; pl. 2, figs. 17-19

2014 Kathina aquitanica. Hottinger, p. 100; pl. 4.4, figs. 1-14; pl. 6.2, figs. 1-7

Material. Sample Se 1 from Serraduy section (Fig. 4); sample Cm 3 from Campo section (Fig. 5); sample G 3 from Garralda section (Fig. 7); samples An 3, An 9 and An 10 from Andia section (Fig. 9); sample L 24 from Lizarraga section (Fig. 10); sample Aix 19 from AixolaErmua section (Fig. 14) and sample Ur 18 Urko section (Fig. 15).

Description. Bilamellar perforate specimens with trochospiral growth and lenticular morphology. The ventral side is more convex than the dorsal side (Fig. 20I', M', P'). The test surface is smooth, without ornamentation. The umbilicus, with a structure typical of the Kathininae, shows a solid umbilical mass pierced by funnels (Fig. 20L', O'). Specimens show a small umbilical plate and a tiny spiral canal (Fig. 200'). The proloculus has a diameter of $70 \mu \mathrm{m}$. The diameter of the adult shell varies from 0.7 to $1 \mathrm{~mm}$ with $2-3$ whorls and the height from 0.5 to $0.6 \mathrm{~mm}$.

Distribution. This species occurs in the depositional sequence Da-2 DS from Urko section (Fig. 15) and in the Se/Th-1 DS from Serraduy section (Fig. 4), Campo section (Fig. 5), Garralda section (Fig. 7), Andia section
(Fig. 9), Lizarraga section (Fig. 10) and Aixola-Ermua section (Fig. 14).

Biozone. $K$. aquitanica was characterized by Hottinger (2014) and attributed to the SBZ 3. The presence of this species in the Da-2 DS in AixolaErmua section (Fig. 13) and in Urko section (Fig. 15) implies extending its biostratigraphic range from SBZ 2 to SBZ 4.

\section{Kathina pernavuti SIREL, 1972 Fig. 20Q' $-X^{\prime}$}

1972 Kathina pernavuti. Sirel, p. 289; pl. 5, fig. 7

2014 Kathina pernavuti SIREL. Hottinger, p. 101; pl. 6.4, figs. $1-22$

Material. Sample Cm 8 from Campo section (Fig. 5) and sample Salv 5 from Salvatierra de Esca section (Robador, 2005, Annex, p. 92-95).

Description. Bilamellar perforate, small-size test with low-trochospiral growth. The dorsal side is more convex than the ventral one (Fig. 20Q' $-R^{\prime}, V^{\prime}, 20 W^{\prime}$ ). The solid umbilical structure is pierced by funnels (Fig. 20R', S', V'). The folia can be clearly observed (Fig. 20R', X'). The diameter of the proloculus is around 40-50 $\mu \mathrm{m}$ (Fig. 20Q'). The adult shell has a diameter of around $1 \mathrm{~mm}$ with 3 whorls and height of around $0.5 \mathrm{~mm}$.

Distribution. This species has been identified in the Campo section (Fig. 4) in Se/Th-1 DS with the species assemblage indicated in the aforementioned figure.

Biozone. According to Hottinger (2014) the biostratigraphic range of this species extends from SBZ 3 to SBZ 4.

GENUS Elazigina SIREL Type species: Kathina subsphaerica, SIREL

\section{Elazigina dienii (HOTTINGER, 2014) \\ Fig. 20Y'-B"}

2000 "Plumokathina" dienii. Peybernès et al., p. 4647; fig. 5

2001 Plumokathina sp. Ogorolec et al., pl. 10, fig. 8 2014 Plumokathina dienii Hottinger, p. 110; figs. 3.5J, 6.1A-N; pl. 6.8, figs. 1-21

Material. Sample G 2 from Garralda section (Fig. 7); sample L 3 from Lizarraga section (Fig. 10); sample Aix 9 from Aixola-Ermua section (Fig. 14) and samples Ur 15, Ur 17 and Ur 18 from Urko section (Fig. 15). 
Description. Small, bilamellar perforate specimens with sharp periphery (Fig. 20Y'-A") and low-trochospiral growth. The dorsal and ventral sides are convex. The umbo has funnels (Fig. 20Z', B"). The feathering of the intraseptal interlocular space is marked (Fig. 20Y'-B"). The proloculus is between $50-120 \mu \mathrm{m}$ in diameter (Fig. $\left.20 \mathrm{~A}^{\prime \prime}\right)$. The adult shell has a diameter of around $1.0 \mathrm{~mm}$ with 3 whorls and a height of $0.5-0.6 \mathrm{~mm}$.

Distribution. This species is present in the Da-2 DS from Garralda section (Fig. 7), Lizarraga section (Fig. 10), Aixola-Ermua section (Fig. 14) and in Urko section (Fig. 15) with the species assemblage indicated in the aforementioned figures.

Biozone. According to Hottinger (2014) this species belongs to SBZ 2. It can be considered as a marker of this biozone.

\section{Elazigina lenticula (HOTTINGER, 2014) Fig. 21A}

1972 Rotalia? sp. 3. Samuel et al. pl. 38, figs. 1-2 1998 Plumokathina sp. Accordi et al. pl. 14, fig. 6 2014 Plumokathina lenticula Hottinger, p. 110 and 117; pl. 6.9, figs. 1-6; pl. 6.10, figs. 1-12

Material. Samples An 3, An 8 and An 9 from Andia section (Fig. 9); sample L 26 from Lizarraga section (Fig. 10); samples K 1 and K 2 from Korres section (Fig. 13) and samples Er 4 and Er 5 from Aixola-Ermua section (Fig. 14).

Description. The test is bilamellar-perforated with trochospiral chamber arrangement. The morphology is lenticular with inflated umbonal area and rounded periphery. The dorsal and ventral sides have similar convexities (Fig. $21 \mathrm{~A}, \mathrm{C}-\mathrm{E}, \mathrm{G}-\mathrm{J})$. The adult shell has a diameter of around $1.6 \mathrm{~mm}$ with 3 whorls and a height of around $0.95 \mathrm{~mm}$. The diameter of the proloculus varies from 0.130 to $0.160 \mu \mathrm{m}$ (Fig. 21A, E, I, K). The feathering of the intraseptal interlocular space is marked (Fig. 21C-D, F-H).

Distribution. This species is present in the depositional sequences Se/Th-1 DS from Andia section (Fig. 9) and in Lizarraga section (Fig. 10). It aslo occurs in the Th-2 DS from Korres section (Fig. 13) and in Aixola-Ermua section (Fig. 14) with the species assemblage indicated in the aforementioned figures.

Biozone. According to Hottinger (2014) the biostratigraphic range of this species extends from SBZ 3 to SBZ 6.

\footnotetext{
Elazigina subsphaerica (SIREL, 1972) Fig. 21K-N
}

1972 Kathina subsphaerica. Sirel, p. 287; pl. 5, fig. $1-5$

1972 Kathina selveri SMOUT. Sirel, p. 290; pl. 5, fig. 6 1983 Kathina aff. subsphaerica SIREL. Rahaghi, pl. 36, figs. $17-18$

1983 Kathina gr. selveri SMOUT. Rahaghi, pl. 36, figs. $12-15$

1988 Kathina selveri SMOUT. Drobne et al., pl. 26, fig. 9

1998 ?Kathina subsphaerica SIREL. Accordi et al., p. 200; pl. 16, figs. 1,3

2004 Smoutina? subsphaerica (SIREL). Sirel, p. 12; pl. 8, figs. 1-21

2012 Elazigina subsphaerica SIREL, p. 274-275; pl. 2, figs. 1-17; text fig. 6A-D

2014 Plumokathina subsphaerica (SIREL). Hottinger, p. 117-118; pl. 6.9, figs. 7-16

2015 Elazigina subsphaerica (SIREL). Sirel, pl. 30, figs. 1-9

2018 Elazigina subsphaerica (SIREL). Sirel, pl. 8, figs. $1-11$

2018 Pseudokathina selveri SMOUT. Sirel, pl. 14, figs. $1-9$

Material. Sample Er 5 from Aixola-Ermua section (Fig. 14).

Description. Large sized specimens with bilamellarperforated test and trochospiral growth. The morphology is typically subspherical with an angular but unkeeled periphery. The adult shell has a diameter that varies from $1.3-1.4 \mathrm{~mm}$ with 2 whorls and height of around $1.20 \mathrm{~mm}$. The diameter of the proloculus is about $0.160-0.170 \mu \mathrm{m}$ in diameter (Fig. 21K, L).

Distribution. This species has been identified in Th-2 DS from Aixola-Ermua section (Fig. 14) with the species assemblage indicated in the aforementioned figure.

Biozone. According Hottinger (2014) the biostratigraphic range of this species is SBZ 4, from which it can be considered a marker.

\section{Subfamily Daviesininae HOTTINGER GENUS Daviesina SMOUT Type species: Daviesina khatiyahi SMOUT}

\section{Daviesina praegarumnensis HOTTINGER, 2014 Fig. 22A-C}

2014 Daviesina praegarumnensis n. sp. Hottinger, p. 144; fig. 7.1N-R; pl. 7.18, figs. 1-34

Material. Samples Cm 3 and Cm 6 from Campo section (Fig. 5) and sample L 3 from Lizarraga section (Fig. 10). 

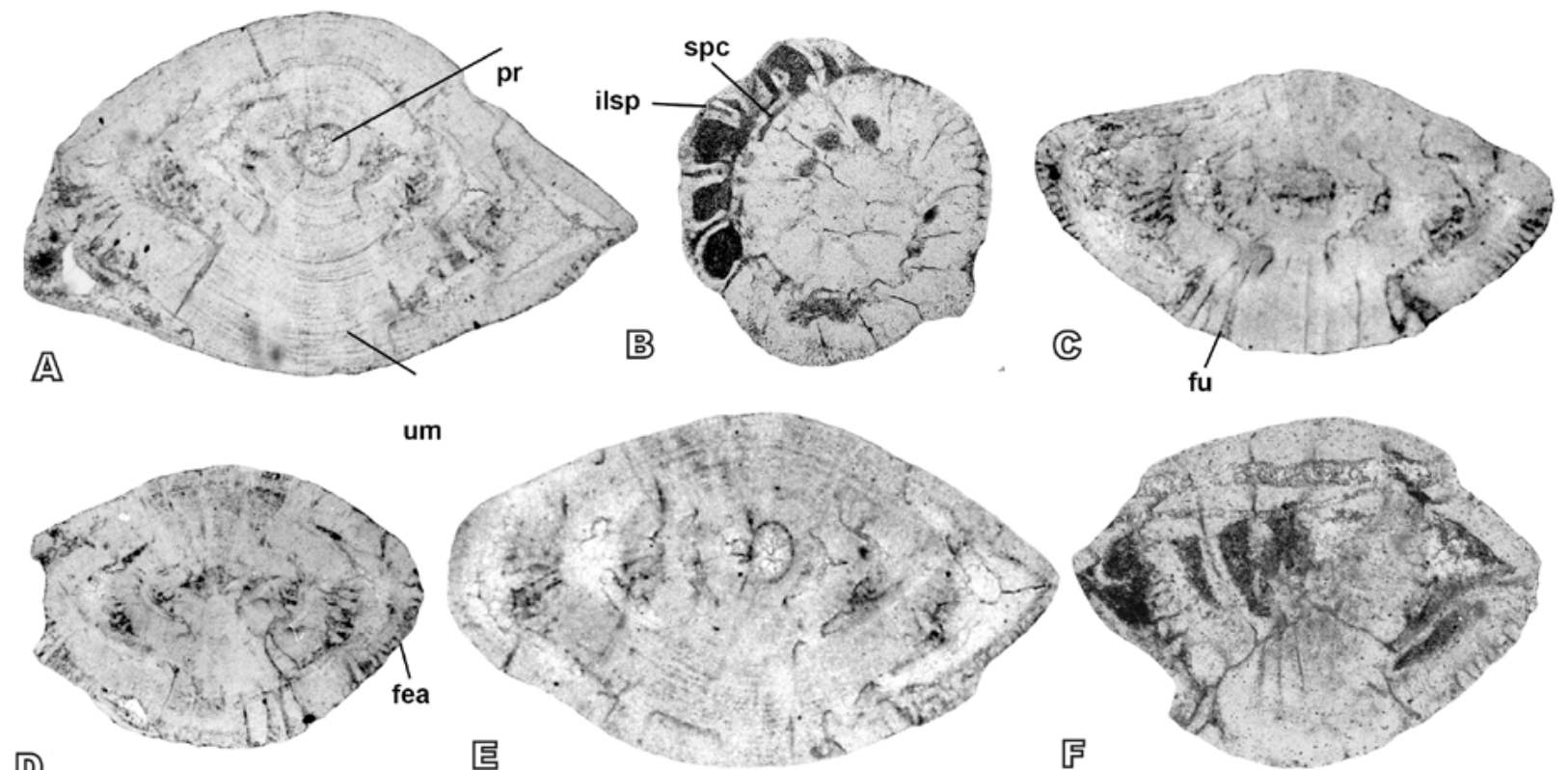

D
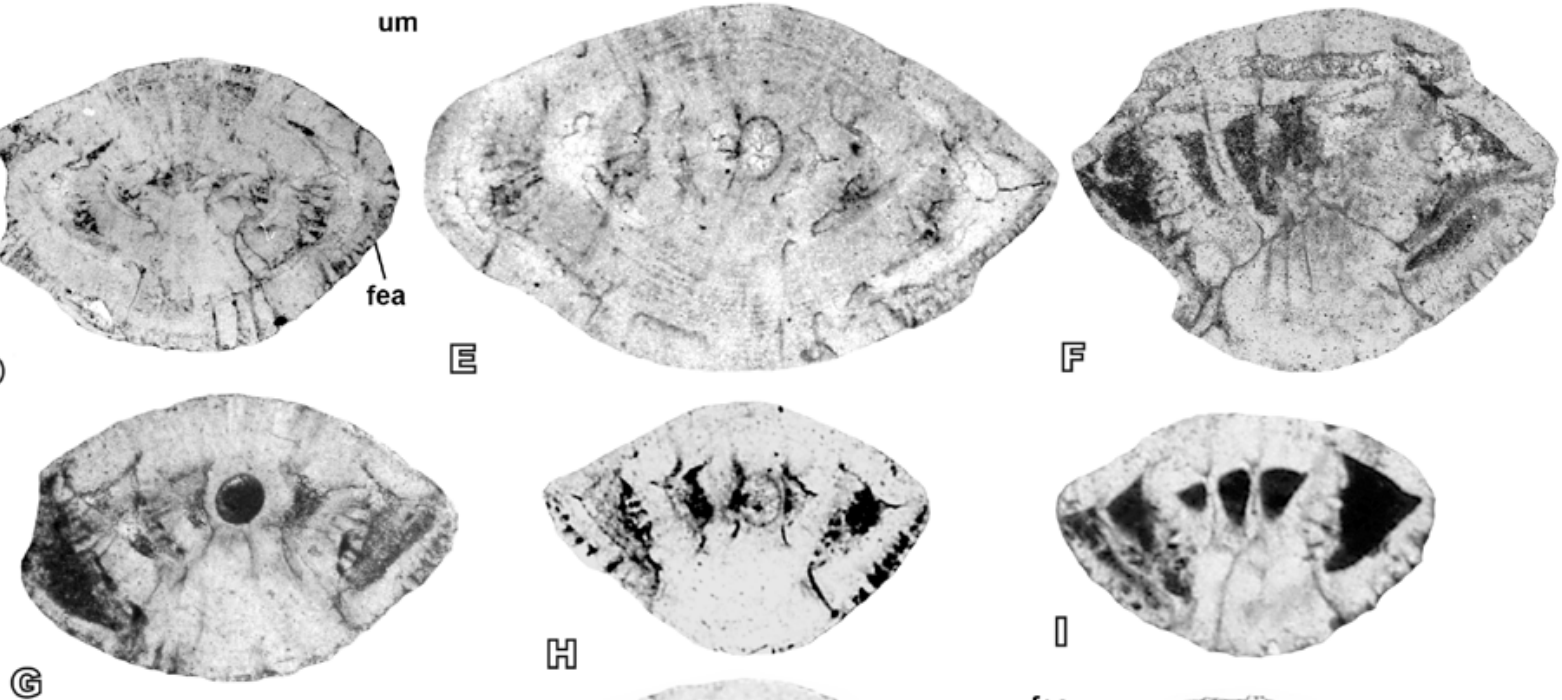

(G)
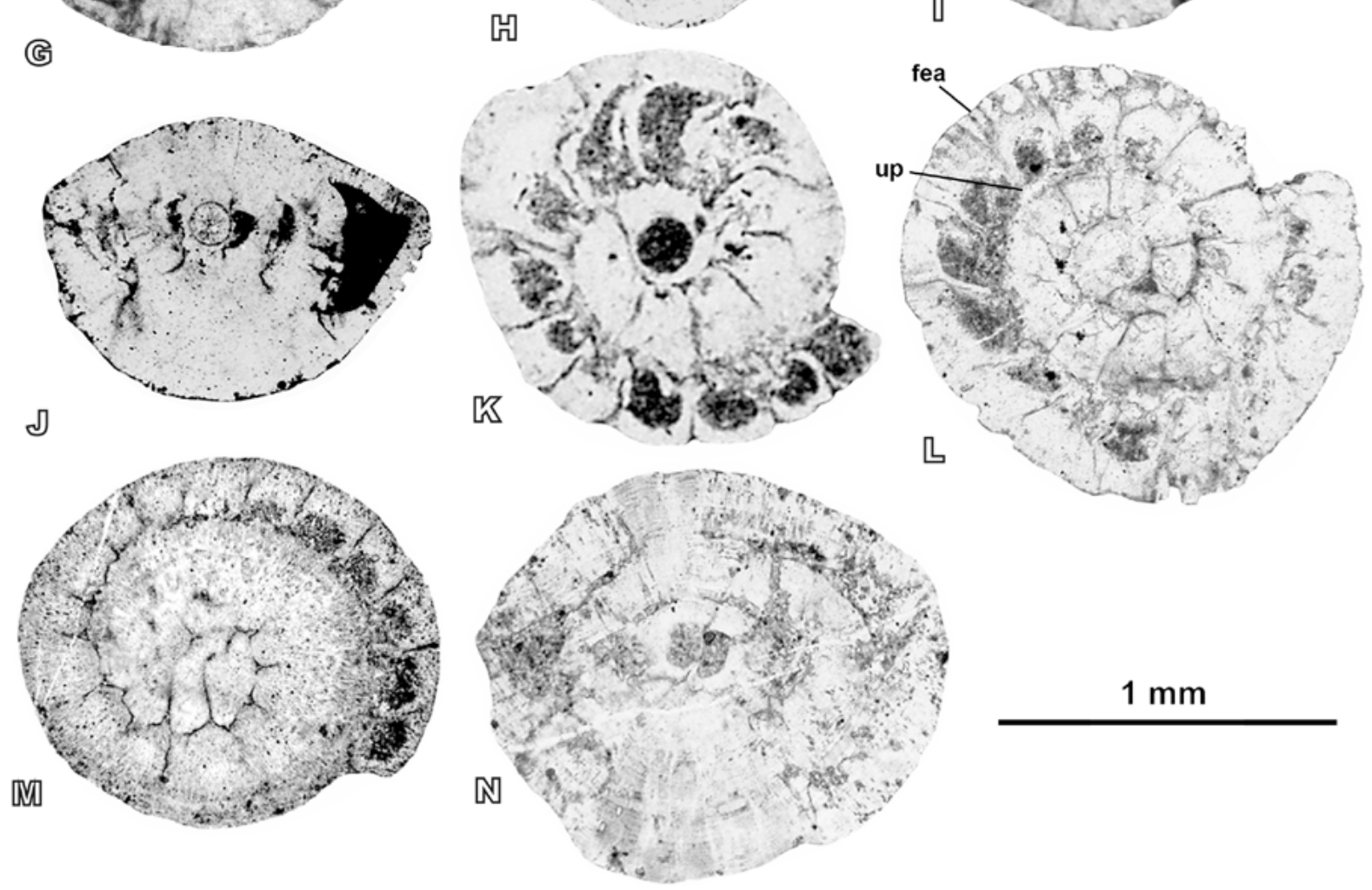

$1 \mathrm{~mm}$

FIGURE 21. Paleocene Larger Foraminifera from the Pyrenean Basin. A-J: Elazigina lenticula (HottIngeR, 2014) Specimens A and E from K 2; B, C and D from sample K 1; F and G from L 26 and H-J from Er 5. K-N: Elazigina subsphaerica (sIREL, 1972) Specimens from sample Er 5. Abbreviations: pr: proloculus, um: umbilical umbo, up: umbilical plate, ilsp: intraseptal interlocular space, spc: spiral canal; fu: funnel, fea: feathering interlocular space 
Description. The test is bilamellar perforate with trochospiral growth and sub-lenticular morphology. The dorsal side is decorated with beads and piles, while the ventral side shows an umbo with funnels. The equatorial diameter is around $1 \mathrm{~mm}$ with $19-20$ chambers. The diameter of the proloculus is around $40 \mu \mathrm{m}$.

Biozone. The data presented herein validate the biostratigraphic range SBZ 2-SBZ 3 for this species, as given by Hottinger (2014).

\section{Daviesina garumnensis TAMBAREAU, 1972 Fig. 22D-E}

1972 Daviesina garumnensis. Tambareau, p. 208; pl. 12, figs. $2-5$

1980 Daviesina garumnensis TAMBAREAU. Caus et al., p. 1058; text-fig. 7A-D; pl. 3, figs. 4-6

2014 Daviesina garumnensis TAMBAREAU. Hottinger, p. 144; fig. 7.1N-R; pl. 7.18, figs. 1-34

Material. Sample Se 2 from Serraduy section (Fig. 4), sample Cm 9 from Campo section (Fig. 5), samples K 1 and K 2 from Korres section (Fig. 13) and sample Er 5 from Aixola-Ermua section (Fig. 14) and Le Quillet and Cérisols outcrops, located in Petites Pyrénées, France (Tambareau,1972, v. 1, p. 53).

Description. The test is bilamellar perforate with lenticular morphology and trochospiral growth. The spiral growth pattern is alike the one of operculiniform foraminifera. Beads and piles can be found in dorsal and ventral sides. The equatorial length is $3.2 \mathrm{~mm}$ and the thickness is $1.8 \mathrm{~mm}$ for 15 chambers. The diameter of the proloculus of megalospheric forms is about $350 \mu \mathrm{m}$.

Remarks. This species is larger than $D$. praegarumnensis described by Hottinger (2014), which he considered a phylogenetic ancestor of D. garumnensis.

Distribution. This species has been identified in Th-2 DS in Serraduy section (Fig. 4), Campo section (Fig. 5), Korres section (Fig. 13) and Aixola-Ermua section (Fig. 14) with the species assemblage indicated in the aforementioned figures.

Biozone. The data presented here validate the biostratigraphic range of D. garumnensis as SBZ 4, from which it can be considered a marker, as previously proposed by Serra-Kiel et al. (1998) and Hottinger (2014).

\section{Superfamily: Planorbulinoidea SCHWAGER Family: Planorbulinida SCHWAGER \\ Subfamily: Planorbulininae SCHWAGER GENUS Planorbulina D'ORBIGNY Type species: Planorbulina mediterranensis D'ORBIGNY}

Two specimens architecturally close to Planorbulina: $P$.? antiqua and P.? cretae were identified in the material studied. The data presented below as well as the observations from other authors (Hofker, 1966; Hottinger in Peybernès et al., 2000; Pignatti in Accordi et al., 1998), suggest that a revision of the architecture of these species is needed in
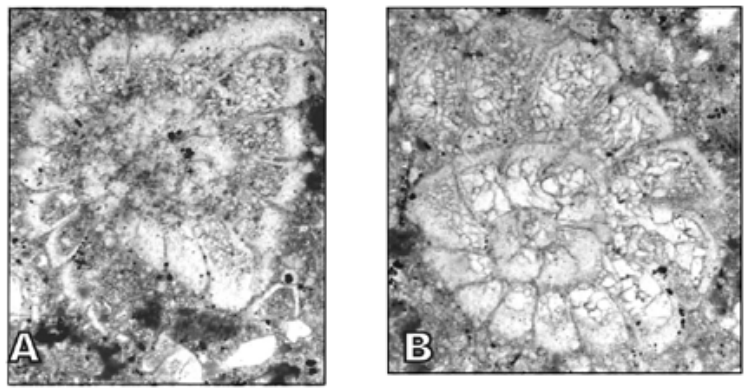

$1 \mathrm{~mm}$

$1-3$

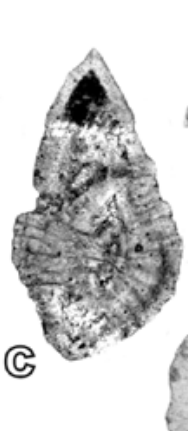

D
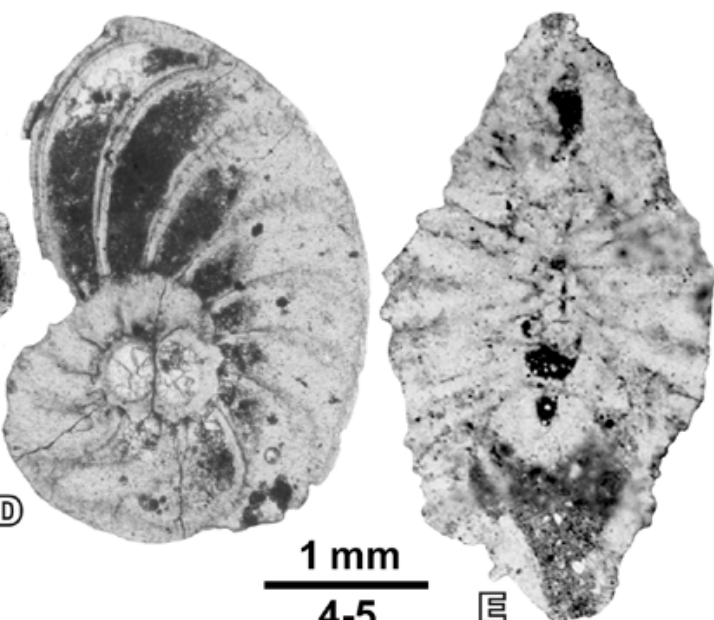

FIGURE 22. Paleocene Larger Foraminifera from the Pyrenean Basin. A-C: Daviesina praegarumnensis HotTINGER, 2014. A oblique uncentered equatorial section; B slightly oblique centred equatorial section; C uncentered axial section, note the funnels in the umbo. Specimens A and B from sample Cm 6 and C from sample Cm 3. D-E: Daviesina garumnensis tambareAu, 1972. D equatorial section; E uncentered axial sections. Specimen D from Le Quillet outcrop and E from sample Er 5. 
order to clarify their generic attribution. The two species show significant architectural differences, especially as regard their ornamentation, which are of generic rank. Nonetheless, not enough material is available here to carry out such a revision.

\section{Planorbulina? antiqua MANGUIN, 1960 Fig. 23A-H}

1960 Planorbulina antiqua. Mangin, p. 275, figs. 44ac

1972 Planorbulina cretae (MARSSON). Samuel et al., pl. 51, fig. 2

1969 Planorbulina cretae (MARSSON). Bignot and Larsonneur, pl.3, fig.6

Material. Samples Urb 1, Urb 2, Urb 3, Urb 4 from Urbasa Pass section (Fig. 11) and sample Ur 4 from Urko section (Fig. 15).

Description. The test is bilamellar-perforate with flattened morphology. The wall is composed of a thin, perforate outer layer and a thin dark inner layer. The chambers show arcuate outline in axial section. The proloculus is spherical with a diameter of ca. 40-60 $\mu \mathrm{m}$ (Fig. 23E, G). The apertures are located at the junction of chambers.

Distribution. This species has been identified in the depositional sequence Ma-Da DS from Urbasa Pass section (Fig. 11) and in Da-1 DS from Urko section (Fig. 15) with the species assemblage indicated in the aforementioned figures.

Biozone. According to Bignot and Larsonneur (1969) and to the observations presented here, P.? antiqua has a biostratigraphic range from Maastrichtian to SBZ 2.

\section{Planorbulina? cretae (MARSSON, 1878)}

Fig. 23I-M

1969 Planorbulina cretae (MARSSON). Bignot and Larsonneur, p. 34, 38; pl. 2, figs. 5-6; pl. 3, figs. 1-6 1972 Planorbulina cretae (MARSSON). Samuel et al., pl. 49, figs. 1-2; pl. 50, figs. 1-2; pl. 51, figs. 1 and 3 1998 Planorbulina cretae (MARSSON). Sirel, p. 104; pl. 16, figs. 4-12

1998 ?Planorbulina cretae (MARSSON). Accordi et al., pl. 11 , fig. 8

2015 Planorbulina cretae (MARSSON). Sirel, pl. 1, figs. 4-12

2018 Planorbulina cretae (MARSSON). Sirel, pl. 1, figs. 4-12

Material. Sample Te 2 from Tena section (Fig. 6), sample An 10 from Andia section (Fig. 9), samples L 2, L
8, L 9 and L 12 from Lizarraga section (Fig. 10), samples Urb 1, Urb 6, Urb 7, Urb 25, Urb 27 and Urb 28 from Urbasa Pass section (Fig. 11); sample Le 2 from Leortza section (Fig. 12); samples Aix 5, Aix 12, Aix 15, Aix 16, Aix 18, Aix 19, Aix 20, and Er 5 from Aixola-Ermua section (Fig. 14) and samples Ur 6, Ur 13, Ur 14 and Ur 17 from Urko section (Fig. 15).

Description. The test is bilamellar-perforate with flattened morphology. The wall is composed of a thick, perforate outer layer and a thin, inner layer. Between the two layers, there is a dark median layer. In axial section, chambers show an arcuate outline. The proloculus is spherical with a diameter of around 100-120 $\mu \mathrm{m}$ (Fig. 23L). The apertures are located at the junction of chambers.

Remarks. $P$. cretae differs from $P$. antiqua by the larger dimensions of the test, by having a thicker wall and by the presence of beads on the dorsal side.

Distribution. This species is present in the depositional sequence Ma-Da DS from Urbasa Pass section (Fig. 11). It also occurs in the Da-1 DS from Lizarraga section (Fig. 10), Urbasa Pass section (Fig. 11), Aixola-Ermua section (Fig. 14) and in Urko section (Fig. 15); in the Da-2 DS from Lizarraga section (Fig. 10), Aixola-Ermua section (Fig. 14) and in Urko section (Fig. 15); in the Se/Th-1 DS from Tena section (Fig. 6); Andia section (Fig. 9); Lizarraga section (Fig. 10); Urbasa Pass (Fig. 11); Leortza section (Fig. 12) and Aixola-Ermua section (Fig. 14); and finally in the Th-2 DS from Aixola-Ermua section (Fig. 14) with the species assemblage indicated in the aforementioned figures.

Age. According to Bignot and Larsonneur (1969) and to the observations presented here $P$.? cretae has a biostratigraphic range Maastrichtian-Paleocene.

\section{ACERVULINOIDEA SCHULTZE \\ Family: Acervulinidae SCHULTZE \\ GENUS Solenomeris DOUVILLЙ}

Type species: Solenomeris ogormani, DOUVILLй

\section{Solenomeris cf. ogormani DOUVILLЙ, 1924}

Fig. 23N

2003 Solenomeris ogormani DOUVILLÉ. Bassi, p. 339341 ; figs. 1 and 2

Material. Samples Urb 1, Urb 3 and Urb 4 from Urbasa Pass Section (Fig. 11) and sample Le 2 from Leortza section (Fig. 12).

Remarks. Solenomeris was formerly considered as belonging to the red algae. Subsequently the studies of Perrin (1987, 1994) and Bassi (2003) concluded that it 


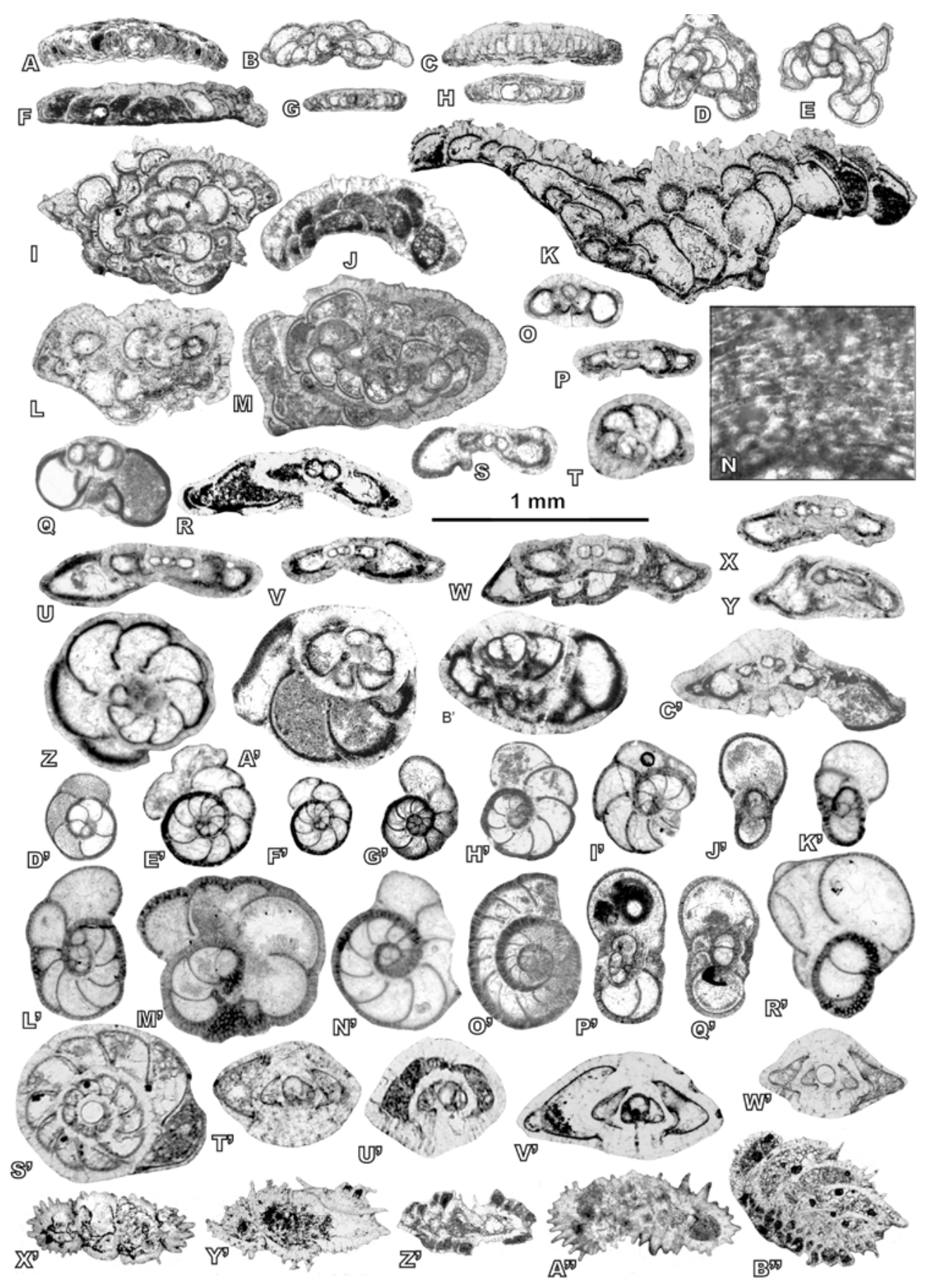

FIGURE 23. Paleocene Larger Foraminifera from the Pyrenean Basin. A-H: Planorbulina? antiqua mangin, 1960. A, B, F and G centered axial section; $\mathbf{C}$ and $\mathbf{H}$ uncentered axial section; D uncentered longitudinal section and $\mathbf{E}$ centered longitudinal section. Specimens A and $\mathrm{G}$ from sample Urb 3; B from sample Urb 4; E from sample Ur 4 and C, D, F and H from sample Urb 1. I-M: Planorbulina? cretae (marssoN, 1878) I, L and M subaxial sections; J and $\mathbf{K}$ oblique longitudinal sections. Specimen I from sample Aix 5; J from sample Le 2; K from sample Er 5; L from sample Urb 1 and $M$ from sample Ur 6. N: Solenomeris cf. ogormani DouviLLÉ, 1924 specimen from sample Urb 1. 0-Y: Stomatorbina? binkhorsti (REUSS, 1862). 0, P, Q, R, W centered axial sections; $\mathbf{T}$ centered equatorial section; $\mathbf{S}, \mathbf{U}, \mathbf{V}, \mathbf{X}$ and $\mathbf{Y}$ uncentered axial sections. Specimen $\mathrm{O}$ from sample Ur 6; $\mathrm{Q}$ from sample Ur 10; R from sample Urb 3; S from sample Urb 4; P, T, U, V, W and X from sample Urb 1 and Y from sample L 4. Z-C': Sistanites iranicus RaHaGHI, 1983 $\mathbf{Z}$ equatorial section; A' and B' oblique sections and C' axial section. Specimens Z-B' from sample L 25 and C' from sample Eu 2. D'-K': Valvulineria patalaensis HAqUE, 1956. D', E', F', G', H' equatorial sections; l' oblique equatorial section and '-'K' axial sections. Specimen D' from sample Ur 10; E', F' and I' from sample Urb 1; G', H' and J' from sample Aix 5 and K' from sample L 4. L'-R' Valvulineria bacetai n. sp. L' Holotype, M' Paratype; N' and O' equatorial sections; P'-Q' axial sections; M' and R' oblique section. Specimens L' and M' from sample K 2; N' from sample Ain 5; O' from sample Urb 31; P' from sample L 27 and Q' and R' from sample Cm 5. S'-W': Gavelinellidae indet. S' centered equatorial section; T'-W' centered axial sections. Specimens S' and U' from sample Aix 16; T' from sample Er 5; V' from sample Beo 5 and W' from Ur 17. X'-B": Coleites cf. reticulosus X' uncentered subaxial section $\mathbf{Y}^{\prime}$ subaxial section, note the carinate margin; $\mathbf{Z}$ ' centered oblique axial section, note the spines and $\mathbf{A}^{\prime \prime}$ peripheral section, note the reticulate ornamentations. Specimen X' from sample Cm 5; Y', Z' and B" from sample L 15 and A" from sample Urb 27. 
should be ascribed to the acervulinid foraminifera. We refer the reader to these studies for further information about the architecture of this species.

Distribution. The morphology of this species suggests a habitus attached to the "seagrass" and substrates of reef environments of the inner shelf. In the material studied this species was found in the depositional sequence Ma-Da DS and Se/Th-1 DS from Leortza section (Fig. 12) with the species assemblage indicated in the aforementioned figures.

Age. According to Perrin $(1987,1994)$ and Bassi (2003) this species has a wide biostratigraphic range, exending from the Paleocene to the Holocene.

Superfamily Discorboidea EHRENBERG

Family: Mississippinidae SAIDOVA

Subfamily: Stomatorbininae SAIDOVA

GENUS Stomatorbina DOREEN

Type species: Lamarckina torrei CUSHMAN AND BEERMЪDE

\section{Stomatorbina? binkhorsti (REUSS, 1862) \\ Fig. 23O-Y}

1972 Mississippina binkhorsti (REUSS). Samuel et al., pl. 36, figs. 1-4

1998 Mississippina? binkhorsti (REUSS). Sirel, p. 103; pl. 1, figs. 2, 3, 5, 8-9

1998 Mississippina? sp. Sirel, pl. 1, figs. 1, 5, 7 and 10 1998 Stomatorbina? binkhorsti (REUSS). Accordi et al., pl. 13, fig. 6

2008 Stomatorbina binkhorsti (REUSS). Pignatti et al., pl. 6 , figs. $1-2$

2010 Stomatorbina binkhorsti (REUSS). Di Carlo et al., p. 66-67; pl. 1, fig. 11

2015 Stomatorbina binkhorsti (REUSS). Sirel, pl. 28, figs. 6-15

2018 Stomatorbina binkhorsti (REUSS). Sirel, pl. 56, figs. 6-15

Material. samples Sample An 10 from Andia section (Fig. 9); L 1, L 2, L 4, L 5, L 6 and L 7 from Lizarraga section (Fig. 10); samples Urb 1, Urb 2, Urb 3, Urb 4, Urb 5, Urb 6, Urb 7, Urb 8, Urb 10, Urb 11, Urb 14, Urb 15, Urb 17 and Urb 18 from Urbasa Pass section (Fig. 11); samples Aix 1, Aix 2, Aix 3, Aix 4, Aix 5, Aix 6 and Aix 9 from Aixola-Ermua section (Fig. 14); samples Ur 1, Ur 2, Ur 3, Ur 4, Ur 5, Ur 6, Ur 7, Ur 9, Ur 10, Ur 13, Ur 14, Ur 16 and Ur 17 from Urko section (Fig. 15).

Description. Low trochospiral test with slightly biconvex morphology. However, some specimens are almost flattened. The periphery of the shell is rounded. The wall is composed of a thick, hyaline outer layer and a dark inner layer. For three whorls, the equatorial diameter is around $1 \mathrm{~mm}$. The proloculus is spherical with a diameter of around 50-80 $\mu \mathrm{m}$ (Fig. 230-Q, S). The dorsal side is smooth; some specimens show small beads (Fig. 23Q, R). Septa are inclined backward and the foramina are located in interiomarginal position (Fig. 23U).

Remarks. Samuel et al. (1972) and Sirel (1998) determined specimens similar to the specimens studied here as Mississippina binkhorsti (REUSS, 1862). However, this species has been ascribed to the genus Stomatorbina by Hottinger in Peybernès et al. (2000), Pignatti in Accordi et al. (1998) and Sirel (2015). Being aware that the taxonomic determination of this species remains uncertain, we have ascribed it tentatively to the genus Stomatorbina.

Distribution. This species is present in the depositional sequence Ma-Da DS from Urbasa Pass section (Fig. 11), in Aixola-Ermua section (Fig. 14). It also occurs in the Da-1 DS from Urbasa Pass section (Fig. 11), Aixola-Ermua section (Fig. 14) and in Urko section (Fig. 15); in the Da-2 DS from Lizarraga section (Fig. 10), Urbasa Pass section (Fig. 11), Aixola-Ermua section (Fig. 14) and in Urko section (Fig. 15) with the species assemblage indicated in the aforementioned figures.

Biozone. The biostratigraphic range of this species is SBZ 1-SBZ 2.

\section{Sistanites iranicus RAHAGHI, 1983 Fig. 23Z-C'}

1983 Sistanites iranica. RAHAGHI, p. 54-55; pl. 34, figs. $1-15$

2008 Sistanites iranicus RAHAGHI. Pignatti et al., pl. 6, fig. 4

2015 Sistanites iranica RAHAGHI. Sirel, pl. 16, figs. $1-13$

2018 Sistanites iranica RAHAGHI. Sirel, pl. 10, figs. 1-11; pl.11, figs. 1-13.

Material. Sample An 10 from Andia section (Fig. 9); sample L 25 from Lizarraga section (Fig. 10); samples Aix 19, Aix 21, Er 4 and Er 5 from Aixola-Ermua section (Fig. 14) and sample Eu 2 from Eguaras section (Robador, 2005, Annex, p. 110-111).

Description. Low-trochospiral test with biconvex morphology. The periphery of the shell is subacute. The wall is composed of a thicker, hyaline outer layer and a dark inner layer. For ten chambers, the equatorial diameter is $0.8 \mathrm{~mm}$. The proloculus is spherical with a diameter of around $100 \mu \mathrm{m}$ (Fig. 23C'). The dorsal and ventral sides ornamented with beads (Fig. 23C'). Septa are inclined. The foramina are cribrate, located in interiomarginal position in the septum. 
Remarks. This species differs from S.? binkhorsti in the more biconvex morphology, larger size of the test and distribution of stolons in the septum.

Distribution. This species is present in the depositional Sequence Se/Th-1 DS from Andia section (Fig. 9); Lizarraga section (Fig. 10), Urbasa Pass section (Fig. 11) and Aixola-Ermua section (Fig. 14). It also occurs in the Th-2 DS from Aixola-Ermua section (Fig. 14).

Biozone. The biostratigraphic range of this species is SBZ 3-SBZ 4.

\section{Family Bagginidae CUSHMAN \\ Subfamily Secovaininae SLITER \\ GENUS Valvulineria CUSHMAN \\ Type species: Valvulineria californica CUSHMAN}

Valvulineria patalaensis HAQUE, 1956

Fig. 23D'-K'

1956 Valvulineria patalaensis. Haque, p. 162; pl. 12, fig. 2

Non 2015 Valvulineria aff. patalaensis HAQUE, Sirel, pl. 10, figs. 1-19

Material. Sample L 4 from Lizarraga section (Fig. 10); samples Urb 1, Urb 2 and Urb 3 from Urbasa Pass (Fig. 11); samples Aix 5 and Aix 9 from Aixola-Ermua section (Fig. 14) and sample Ur 10 from Urko section (Fig. 15).

Description. Lamellar perforate specimens with trochospiral growth and rounded periphery. The chambers are inflated and increase gradually in size. The dorsal side is flat to slightly convex; the ventral side has a depressed umbilicus. The sutures are slightly depressed. The aperture is simple and located in interiomarginal position. The diameter of the test for 14-17 chambers varies from 0.460 to $0.650 \mathrm{~mm}$ and the thickness of adult tests is around $0.370 \mathrm{~mm}$. The diameter of the spherical proloculus is around $45 \mu \mathrm{m}$.

Distribution. This species occurs in the depositional Sequence Ma-Da DS from the Urbasa Pass section (Fig. 11 ); in the Da-1 DS from the Aixola-Ermua section (Fig. 14) and in Urko section (Fig. 15) in the Da-2 DS from the Lizarraga section (Fig. 10) and Aixola-Ermua section (Fig. 14) with the species assemblage indicated in the aforementioned figures.

Biozone. The biostratigraphic range of this species is SBZ 1-SBZ 2.

Valvulineria bacetai $n$. sp. Serra-Kiel and Vicedo Fig. 23W-R'
2018 Valvulineria aff. patalaensis HAQUE. Sirel, figs. $1-19$

Derivation of name. In honour of J.I. Baceta who studied the Paleocene of the Pyrenean basin.

Holotype. specimen illustrated in Figure 23.38. Housed in the palaeontological collections of the Museu de Ciències Naturals de Barcelona, accession number MGB 89845 LP01.01.

Paratype. specimen illustrated in Figure 23.39 is designated paratype. Housed in the palaeontological collections of the Museu de Ciències Naturals de Barcelona, accession number MGB 89845 LP01.02.

Type locality. Located in the Korres section, near the village of Korres. Sample K 2. Coordinate: N 42 $51^{\prime}$ 54.54"/W 2 26' 13.62".

Type level. "Assilina beds", late Thanetian or SBZ 4. Bed of sample K 2 from Korres section.

Material. Samples Cm 3, Cm 4 and Cm 5 from Campo section (Fig. 5); samples L 25 and L 27 from Lizarraga section (Fig. 10); sample Urb 31 from Urbasa Pass section (Fig. 11); sample K 2 from Korres section (Fig. 13) and sample Ain 5 from Aintzioa section (Appendix, pp. 64-65, Robador, 2005).

Diagnosis. Wall finely perforated with low trochospiral growth and rounded periphery. Dimorphism not observed, probably restricted to early stages of growth. Chambers inflated and increasing gradually in size as added. Dorsal side flat; ventral side with depressed umbilicus. Aperture simple and located in interiomarginal position. Sutures slightly depressed. Embryo consisting of a spherical proloculus with a diameter of around $60 \mu \mathrm{m}$ (Fig. 23N'$\left.\mathrm{P}^{\prime}\right)$. Adult specimens with a diameter generally of around $0.800 \mathrm{~mm}$ but reaching up to $1 \mathrm{~mm}$ (Fig. $23 \mathrm{M}^{\prime}$ ) for 28 chambers and 3 whorls (Fig. 230'). Thickness measured $0.441 \mathrm{~mm}$.

Remarks. See previous remarks on $V$. patalaensis concerning the generic attribution.

Distribution. This species is present in the depositional sequence Se/Th-1 DS from Campo section (Fig. 5), Lizarraga section (Fig. 10) and in Urbasa Pass section (Fig. 11). It also occcurs in the Th-2 DS from Korres section (Fig. 13). The species assemblage is indicated in the aforementioned figures.

Biozone. The biostratigraphic range of this species is SBZ 3-SBZ 4. 


\section{Superfamily Chilostomelloidea BRADY Family Gavelinellidae HOFKER}

\section{Gavelinellidae indet.} Fig. 23S'-W'

1972 Gyroidina subangulosa (PLUMMER, 1926). Samuel et al., pl. 37, fig. 1-6

Material. Samples Aix 9, Aix 16, Aix 17, Aix 18 and Er 5 from Aixola-Ermua section (Fig. 14); Ur 2, Ur 3, Ur 6, Ur 8, Ur 10, Ur 11, Ur 13 and Ur 17 from Urko section (Fig. 15); sample Beo 5 from Beoburu section (Robador, 2005, Annex, p. 112).

Description. The test is bilamellar with coarse pores and low-trochospiral growth. The dorsal side is pseudoinvolute, convex and smooth; the ventral side is slightly convex with an umbo with large beads (Fig. 23V', W'). The lamination is composed of a thicker and perforate outer layer and a thin, dark inner layer. The proloculus is spherical with a diameter of $100 \mu \mathrm{m}$ (Fig. 23S', T', W'). The equatorial diameter is $0.880 \mathrm{~mm}$ with 20 chambers, and the thickness $0.490 \mathrm{~mm}$.

Distribution. This species is present in the depositional sequence Da-1 DS from Urko section (Fig. 15). It also occurs in the Da-2 DS from Aixola-Ermua section (Fig. 14) and in Urko section (Fig. 15), in the Se/Th-1 DS from Aixola-Ermua section (Fig. 14) and finally in theTh-2 DS from Aixola-Ermua section (Fig. 14).

Biozone. The biostratigraphic range of this species is SBZ 1?-SBZ 3.

\section{Family Coleitidae LOEBLICH AND TAPPAN GENUS Coleites PLUMMER Type species: Pulvinulina reticulosa PLUMMER}

\section{Coleites cf. reticulosus (PLUMMER, 1927) Fig. 23X'-B"}

1973 Coleites sp. aff. C. reticulosus (PLUMMER, 1926). Ferrer et al. p. 67; fig. 25

1987 Coleites reticulosus (PLUMMER, 1926). Loeblich and Tappan, pl. 726, fig. 1-3

Material. Sample Cm 5 from Campo section (Fig. 5); L 15 from Lizarraga section (Fig. 10) and sample Urb 27 from Urbasa Pass section (Fig. 11).

Description. Hyaline test with low-trochospiral growth (Fig. 23Z'). The chamber sutures are slightly depressed. In axial section, the periphery is carinate. The ornamentation consists of long and thin cross ridges producing a coarsely reticulate pattern in the test surface (Fig. 23A"). In axial section, the ridges appear like spines (Fig. 23X', 23Z').

Remarks. Due to insufficient material the determination of these specimens cannot be further refined.

Distribution. This species is present in the depositional sequence Da-2 DS from Lizarraga section (Fig. 10) and in Urko section (Fig. 15). It also occurs in the Se/Th-1 DS from and Campo section (Fig. 5) and in Urbasa Pass (Fig. 11) with the species assemblage indicated in the aforementioned figures.

Biozone. According to the present study, the biostratigraphic range of this species is SBZ 2-SBZ 3.

\section{Superfamily Nonionoidea SCHULTZE \\ Family Miscellaneidae SIGAL in PIVETEAU \\ Subfamily Miscellaneinae SIGAL in PIVETEAU GENUS Miscellanea PFENDER \\ Type species: Nummulites miscella D'ARCHIAC AND HAIME}

\section{Miscellanea yvettae LEPPIG, 1988 \\ Fig. 24A-C}

1988 Miscellanea sp. 2. Drobne et al. p. 160; pl. 26, figs. 1-4

1988a Miscellanea yvettae. Leppig, p. 702; pl. 1, fig. 2; pl. 2, fig. 2; pl. 3, fig. 2; pl. 5, figs. 1-8

1998 Miscellanea juliettae LEPPIG. Sirel, p. 93; pl. 54, figs. $1-10$

2009 Miscellanea yvettae LEPPIG. Hottinger, p. 5; pl. 7, figs. 9-16; pl. 8, figs. 1-9; pl. 9, figs. 1-12

Material. Sample Cm 4 from Campo section (Fig. 5); sample G 3 from Garralda section (Fig. 7) and samples Le 5 and Le 7 from Leortza section (Fig. 12).

Description. The test is bilamellar perforate with planispiral growth. The lenticular tests are dimorphic and have a thick wall and rounded periphery. The ornamentation is dense and it is composed of piles and pustules. Megalospheric forms show a proloculus with a diameter of around $200-280 \mu \mathrm{m}$. The equatorial diameter in megalospheric forms varies from 1.7 to $1.8 \mathrm{~mm}$ and thickness between $1.0-1.15 \mathrm{~mm}$ for 3 whorls. The microspheric form starts with a very small proloculus followed by chambers planispirally coiled, producing an adult test with an equatorial diameter of $2 \mathrm{~mm}$ and axial thickness of $1.6 \mathrm{~mm}$.

Distribution. This species is present in the $\mathrm{Se} / \mathrm{Th}-1$ DS in the Campo section (Fig. 5), Garralda section (Fig. 7) 

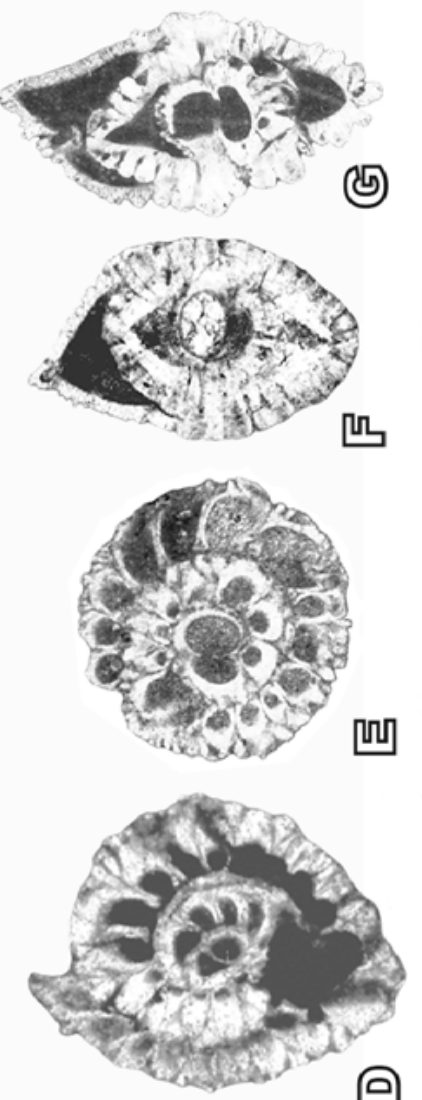

Q
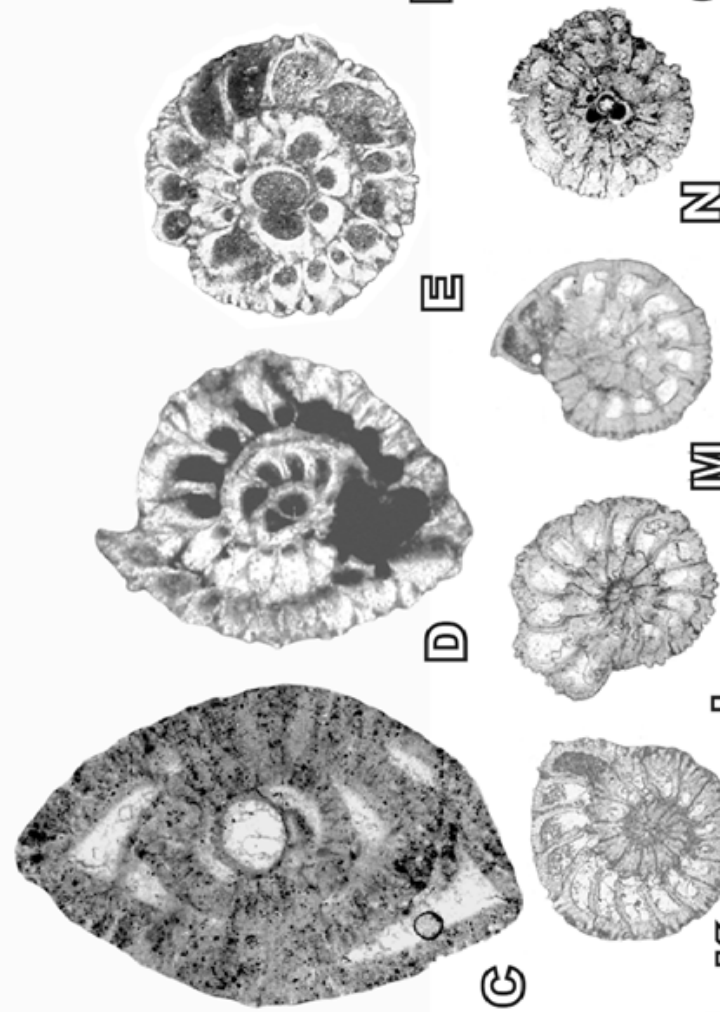

\section{()}

ه
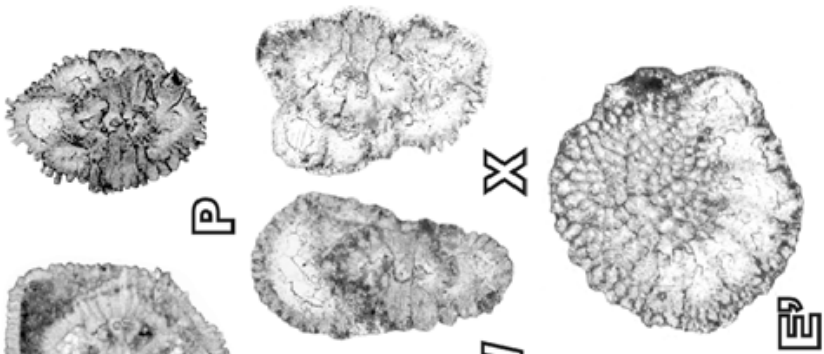

宂

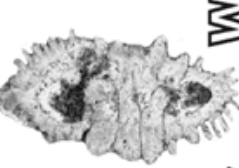

(x)
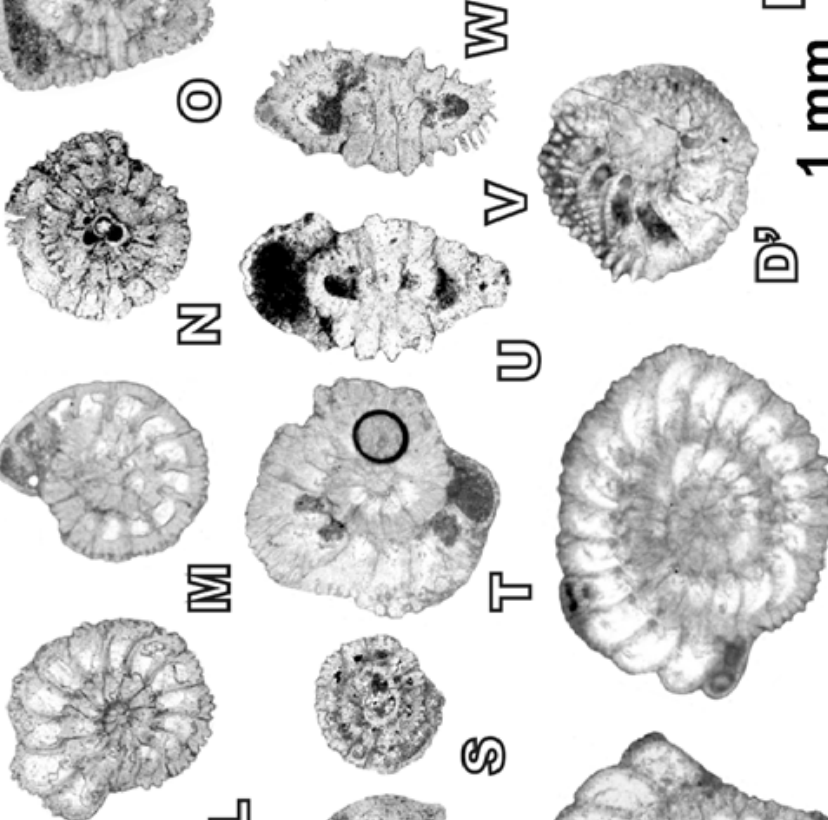

(8)
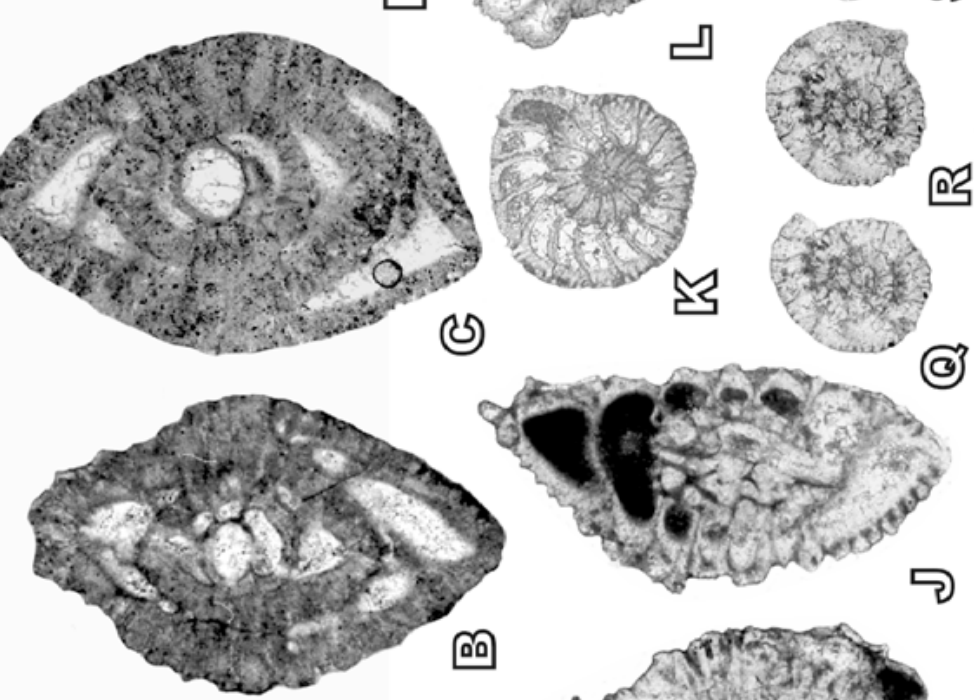

(3)
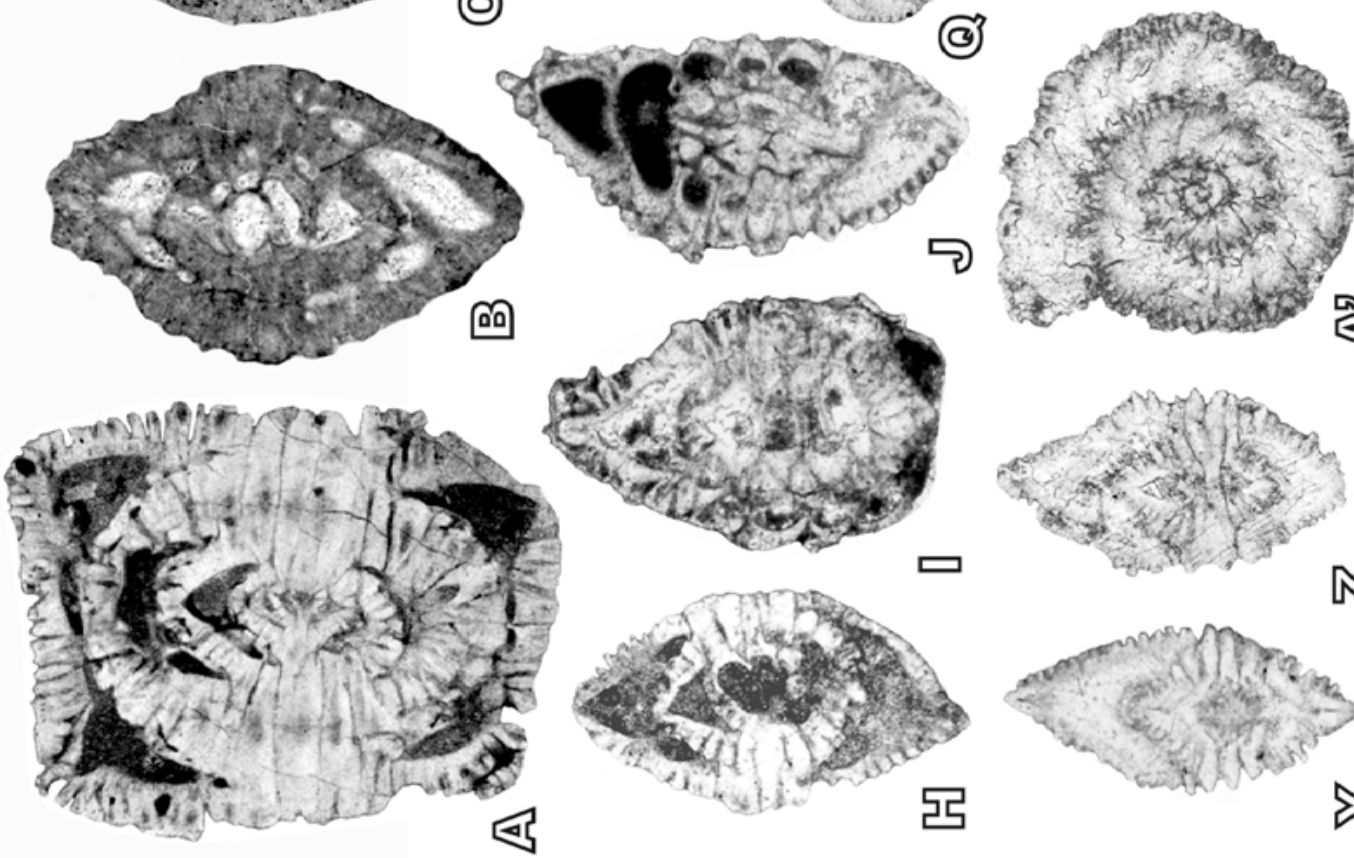

\section{四}

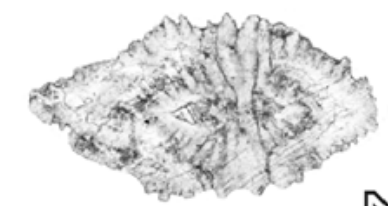

$\mathbb{N}$

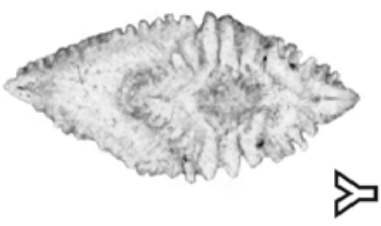

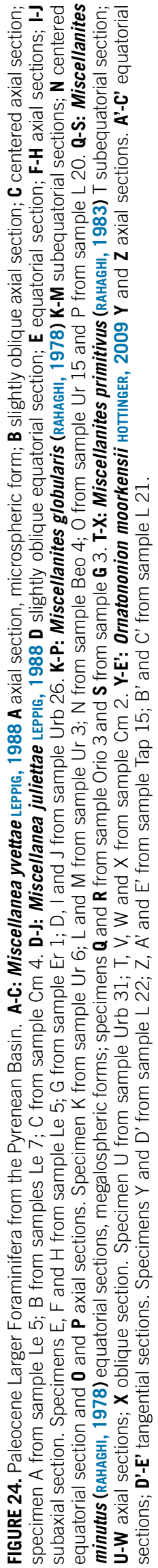


and in Leortza section (Fig. 12) with the species assemblage indicated in the aforementioned figures.

Biozone. The stratigraphic data and the species assemblage confirm the biostratigraphic range given by Leppig (1988a), Serra-Kiel et al. (1998) and Hottinger (2009), who considered this species as a marker of the SBZ 3.

\section{Miscellanea juliettae LEPPIG, 1988 Fig. 24D-J}

1988a Miscellanea juliettae pfenderae. Leppig, p. 700; pl. 1, fig. 4; pl. 2, fig. 4; pl. 3, figs. 4/1 and 4/2; pl. 4, figs. 1-8, non figs. 9-10

2001 Miscellanea juiettae villattae LEPPIG. Ogorelec et al:; pl.10, figs. 1-5

2009 Miscellanea juliettae LEPPIG. Sirel, pl. 4, figs. 7-8 2009 Miscellanea juliettae LEPPIG. Hottinger, p. 6; pl. 1, figs. 21-27; pl. 10, figs. 1-20; pl. 11, figs. 1-11

Material. Samples Urb 26, Urb 29 and Urb 30 from Urbasa Pass (Fig. 11); samples Le 1, Le 2, Le 4 and Le 5 from Leortza section (Fig. 12) and sample Er 1 from Aixola-Ermua section (Fig. 14).

Description. Bilamellar-perforate, planispiral test. The shells are lenticular with thin wall; the periphery is acute without keel. The ornamentation is composed of beads covering the surface at the polar zone and abundant piles covering the lateral surface of the chambers. The megalospheric forms have an equatorial diameter that varies from 1.0 to $1.3 \mathrm{~mm}$ with 3 whorls, and axial thickness of about $0.7-0.8 \mathrm{~mm}$. The megalospheric proloculus is about $160-230 \mu \mathrm{m}$ in diameter.

Distribution. This species is present in Se/Th-1 DS in the Urbasa Pass section (Fig. 11), the Leortza section (Fig. 12), the Aixola-Ermua section (Fig. 14) and in a sample taken from a pebble of the breccia located in TH-2 DS. The species assemblage is indicated in the aforementioned figures.

Biozone. Stratigraphic data and species assemblage confirm the biostratigraphic range given by Leppig (1988a), that leads to consider this species as a marker of SBZ 3, as proposed by Serra-Kiel et al. (1998) and Hottinger (2009).

\section{Subfamily Miscellanitinae HOTTINGER \\ GENUS Miscellanites HOTTINGER Type species: Miscellanea iranica (RAHAGHI)}

\author{
Miscellanites globularis (RAHAGHI, 1978)
}

1978 Miscellanea globularis. Rahaghi, p. 61; pl. 12, figs. $10-20$

1983 Miscellanea globularis RAHAGHI. Rahaghi, p. 61; pl. 42, figs. 1-5 and 7

1998 Miscellanea globularis? RAHAGHI. Sirel, p. 97; pl. 58; figs. 1-8, 10, 12-14

2000 "Miscellanites" globularis (RAHAGHI). Peybernès et al., p. 47; fig. 4a

2009 Miscellanites globularis (RAHAGHI). Hottinger, p. 10; pl. 22, figs. 1-24; 7-13

2015 Unidentified miscellanid genus. Sirel, pl. 8, figs. $1-7$

2018 Burdurina selandinica. Sirel, pl. 19, figs. 1-7

Material. Samples G 1 and G 2 from Garralda section (Fig. 7); sample An 9 from Andia section (Fig. 9); samples L 11 and L 20 from Lizarraga section (Fig. 10); samples Urb 8, Urb 10, Urb 11 and Urb 13 from Urbasa Pass section (Fig. 11); samples Aix 4, Aix 6, Aix 9, Aix 16 and Aix 17 from Aixola-Ermua section (Fig. 14); samples Ur 3, Ur 5, Ur 6, Ur 11, Ur 14, Ur 15 and Ur 17 from Urko section (Fig. 15) and sample Beo 4 from Beoburu section (Robador, 2005, Annex, p. 112).

Description. The test is bilamellar perforate with planispiral growth. The morphology is spherical to ovoidal. The surface is covered with pustules. The equatorial diameter in megalospheric forms varies from 0.6 to $0.8 \mathrm{~mm}$ with 3 whorls; the axial thickness is about $0.5 \mathrm{~mm}$. There are 3-4 piles at the polar zones. The protoconch is separated from the deuteroconch by a thin wall. The proloculus diameter varies from 70 to $100 \mu \mathrm{m}$. Chambers have an isometric outline in equatorial section.

Distribution. This species is present in the depositional sequence Da-1 DS from Urbasa Pass section (Fig. 11), in the Aixola-Ermua section (Fig. 14) and in Urko section (Fig. 15). It also occurs in the Da-2 DS from Garralda section (Fig. 7), Lizarraga section (Fig. 10), Urbasa Pass section (Fig. 11), Aixola-Ermua section (Fig. 14) and in Urko section (Fig. 15). Finally, it has been found in the Se/ Th-1 DS from Andia section (Fig. 9) and in Aixola-Ermua section (Fig. 14). The species assemblage is indicated in the aforementioned figures.

Biozone. The stratigraphic data and the associated foraminifera confirm the biostratigraphic range from SBZ 2 to SBZ 3 attributed by Hottinger (2009) to this species.

\section{Miscellanites minutus (RAHAGHI, 1978) Fig. 24Q-S}

1983 Miscellanea minuta. RAHAGHI, p. 62; pl. 43, figs. $1-13$

2008 Miscellanea aff. juliettae LEPPIG. Pignatti et al., 
p. 134 , pl. 6, fig.8-9

2008 Miscellanea cf. juliettae LEPPIG. Pignatti et al., p. 134, pl. 4, fig. 4-5

2009 Miscellanites minutus (RAHAGHI). Hottinger, p. 8-9; pl. 18, figs. 1-21; pl. 19, figs. 1-11

Material. sample G 3 from Garralda section (Fig. 7); sample Orio 3 from a pebble taken from Orio section (p. 248, fig. 75, Baceta, 1996) and sample Bur 3 from Burgi section (Robador, 2005, Annex, pp. 78-79).

Description. The test is bilamellar-perforate with planispiral growth. The morphology is lenticular. In equatorial section, chambers have isometric outline. The proloculus is small (around $40 \mu \mathrm{m}$ in diameter).

Distribution. This species is present in the Garralda section (Fig. 7) in Se/Th-1 DS with the species assemblage indicated in the aforementioned figure.

Biozone. According to Hottinger (2009) the biostratigraphic range of this species is SBZ 3.

\section{Miscellanites primitivus (RAHAGHI, 1983) \\ Fig. 24T-X}

1983 Miscellanea primitiva. Rahaghi, p. 61; pl. 42, figs. 8-16

1998 Miscellanea sp. 2. Pignatti et al., pl. 4, figs. 8-16 2008 Miscellanea aff. iranica RAHAGHI. Pignatti et al., pl. 6, figs. 5-6

2009 Miscellanites primitivus (RAHAGHI). Hottinger, $\mathrm{p}$. 8; pl. 16, figs. 1-24; pl. 17, figs. 1-16

2009 Akbarina primitiva (RAHAGHI). Sirel, p. 419-420; pl. 3, figs. 1-8

2015 Akbarina primitiva (RAHAGHI). Sirel, pl. 8, figs. 8-23

2018 Akbarina yarisliensis. Sirel, pl. 19, figs. 8-23

Material. Samples $\mathrm{Cm} \mathrm{2,} \mathrm{Cm} 3$ and $\mathrm{Cm} 4$ from Campo section (Fig. 5); sample An 10 from Andia section (Fig. 9); samples L 25, L 26 and L 27 from Lizarraga section (Fig. 10) and sample Urb 31 from Urbasa Pass section (Fig. 11).

Description. The test is bilamellar perforated with planispiral growth. The shell is small with lenticular morphology and rounded periphery. In megalospheric forms, the equatorial diameter varies from 0.7 to $0.95 \mathrm{~mm}$, and axial thickness from 0.45 to $0.50 \mathrm{~mm}$. The ornamentation is composed of thick piles at the polar zone and fine piles on the lateral surface. The diameter of the megalospheric forms varies from 60 to $80 \mu \mathrm{m}$. The septa are curved and inclined backward at the top of the chambers.
Distribution. This species is present in Se/Th-1 DS in the Campo section (Fig. 5), Andia section (Fig. 9), Lizarraga section (Fig. 10) and in Urbasa Pass section (Fig. 11) with the species assemblage indicated in the aforementioned figures.

Biozone. Stratigraphic data and associated foraminifera confirm the biostratigraphic range of SBZ 3 attributed to this species by Hottinger (2009).

\section{GENUS: Ornatononion HOTTINGER}

Type species: Nonion? ornatum VAN BELLEN in MOORKENS

\section{Ornatononion moorkensii HOTTINGER, 2009 Fig. 24Y-E}

2009 Ornatononion moorkensii. Hottinger, p. 9-10; pl. 20, figs. 1-13; pl. 21, figs. 1-16

Material. Sample G 1 from Garralda section (Fig. 7); samples L 12, L 21 and L 22 from Lizarraga section (Fig. 10); samples Urb 8 and Urb 11 from Urbasa Pass section (Fig. 11); samples Ur 6, Ur 8, Ur 14, Ur 15, Ur 17 and Ur 18 from Urko section (Fig. 15) and sample Tap 15 from Tapla section (Robador, 2005, Annex, p. 48-49).

Description. The test is bilamellar perforated with planispiral growth. The morphology of the shell is lenticular with acute poles. The ornamentation is composed of pustules and heavy piles in the polar zones. The megalospheric forms have an equatorial diameter that varies from 1.2 to $1.3 \mathrm{~mm}$, and axial thickness of around $0.6 \mathrm{~mm}$. The diameter of the proloculus of megalospheric forms is around $100 \mu \mathrm{m}$.

Distribution. This species is present in the depositional sequences Da-1 DS from Urbasa Pass section (Fig. 11) and in Urko section (Fig. 15). It also occurs in the Da-2 DS from Garralda section (Fig. 7), Lizarraga section (Fig. 10) and Urko section (Fig. 15).

Biozone. The stratigraphic data and the foraminifera associated with this species validate its biostratigraphic attribution to SBZ 2 as given by Hottinger (2009).

\section{Superfamily Nummulitoidea DE BLAINVILLE Family Nummulitidae DE BLAINVILLE GENUS: Nummulites LAMARCK}

Type species: Camerina laevigata BRUGUIURE

"Operculina" heberti MUNIER-CHALMAS, 1884 [=
Nummulites heberti (MUNIER-CHALMAS) sensu
Tosquella, 1995]
Fig. 25J-O


1955 Operculina heberti MUNIER-CHALMAS. Mangin, $\mathrm{p}$. 241 ; pl. 3, figs. $1-8$

1962 Operculina heberti MUNIER-CHALMAS. Villatte, $p$. 291; pl. 21, figs. 1-2; pl. 22, figs. 3-4

1964 Operculina heberti MUNIER-CHALMAS. Hottinger, pl. 1, figs. 7a-e

1972 Operculina heberti MUNIER-CHALMAS. Tambareau, p. 221; pl. 13, figs. 1-2; pl. 14, figs. 3-4

1977 Operculina heberti MUNIER-CHALMAS. Hottinger, p. 71; text-figs. $27 \mathrm{M}-\mathrm{O}, 28$

1995 Nummulites heberti (MUNIER-CHALMAS). Tosquella, p. 293; pl. 2, figs. 1-9

1998b Nummulites heberti (MUNIER-CHALMAS). Tosquella and Serra-Kiel, p. 95-96; pl. 17, figs. 1-3

2008 “Operculina” heberti (MUNIER-CHALMAS). Pignatti et al., pl. 2, fig. 2

Material. Sample Te 2 from Tena section (Fig. 6); samples Urrob 3 and Urrob 4 from Urrobi section (Fig. 8); samples An 1, An 2 and An 11 from Andia section (Fig. 9); samples L 24, L 25 and L 26 from Lizarraga section (Fig. 10); samples Urb 22, Urb 23 and Urb 25 from Urbasa Pass section (Fig. 11); sample Le 3 from Leortza section (Fig. 12); samples Aix 15, Aix 16, Aix 17, Aix 18, Aix 21, Er 1 and Er 2 from Aixola-Ermua section (Fig. 14); sample from Bouzin outcrop located in the Petites Pyrénées (north Pyrenean realm) see Villatte (1962), Tambareau et al. (1992b, p. 14) and Schaub (1981, p 193, fig. 45) and sample Narp outcrop from Béarn (France), see Tambareau et al. (1994a, p. 36).

Description. The morphology of the microspheric and megalospheric form is flattened. The microspheric forms have a maximum equatorial diameter of ca. $1 \mathrm{~mm}$, while the megalospheric are around $0.6 \mathrm{~mm}$ across. The spire is operculiniform, slightly irregular, opening rapidly. The ornamentation is composed of piles over the septa and between them. Diameter proloculus in megalospheric forms varies from 200 to $250 \mu \mathrm{m}$. The septa are straight with dense distribution and recurved in the top of the chambers.

Remarks. This species was originally accommodated within genus Operculina. However, according to Tosquella (1995), a trabecular system can be observed in exceptionally well-preserved specimens from Narp, France (Tambareau et al., 1994a, p. 36), concluding that the species should be ranged in genus Nummulites. This feature is again illustrated here (Fig. 25.15).

However, by transferring the species to Nummulites, it becomes a junior secondary homonym of Nummulites heberti d'Archiac and Haime, 1853. As long as this controversy is not solved, the morphotype should be left in open nomenclature.

Distribution. This species is present in Se/Th-1 DS in the Tena section (Fig. 6), Urrobi section (Fig. 7), Andia section (Fig. 9), Lizarraga section (Fig. 10); Urbasa Pass section (Fig. 11); Leortza section (Fig. 12) and in AixolaErmua section (Fig. 14), in this section the pebbles taken from a breccia in Th-2 DS this species is associated with the species assemblage indicated in the aforementioned figures.

Biozone. The stratigraphic data and the associated foraminifera confirm the biostratigraphic range SBZ 3 attributed by Tosquella (1995), Tosquella and Serra-Kiel (1998b) and Serra-Kiel et al. (1998) to this species.

\section{Nummulites catari TOSQUELLA AND SERRA-KIEL, 1998 Fig. 25P-U}

1998a Nummulites catari. Tosquella and Serra-Kiel, p. 165-171; fig. 1; pl. 1, figs. 1-2; pl. 2, figs. 1-4 1998b Nummulites catari TOSQUELLA AND SERRA-KIEL. Tosquella and Serra-Kiel, p. 96-97; pl. 17, figs. 4-5

Material. Samples from Cérisols and Le Quillet outcrops located in Petites Pyrénées (France) as reported by Tambareau (1972; v.1, p. 53), Tambareau et al. (1992b, p. 14) and Schaub (1981, p 193 and fig. 45).

Description. The morphology of the microspheric forms is flattened with rounded periphery and slightly inflated at the polar regions. The test shows a diameter of $6.55 \mathrm{~mm}$ for 5 whorls. The ornamentation consists of curved filaments and small piles over them in the polar zone. The spire is operculiniform tending to irregular assilinoid. The megalospheric forms show a flattened morphology, with a diameter of $3.3-3.5 \mathrm{~mm}$ and thickness of around $1 \mathrm{~mm}$ for 3 whorls. The spire is regular and opens rapidly. Both generations show a thin marginal cord, and dense septa distribution. Septa straight and strongly recurved in the upper part of the chamber. The proloculus is small in megalospheric forms, with a diameter of around 120-150 $\mu \mathrm{m}$.

Distribution. In the Le Quillet outcrop this species is associated with $A$. yvettae and $A$. azilensis, while in the Cérisols outcrop it is associated with A. azilensis.

Biozone. According to Tosquella and Serra-Kiel (1998b) and Serra-Kiel et al. (1998) its biostratigraphic range is SBZ 4.

\section{GENUS Assilina D'ORBIGNY Type species: Assilina depressa, D'ORBIGNY}

\section{Assilina yvettae SCHAUB, 1981 \\ Fig. 25A-C}

1972 Assilina? sp., Tambareau, p. 217; pl. 13, figs. 9-16; pl. 14, figs. 16-19; pl. 18, figs. 1-2, 4

1981 Assilina yvettae. Schaub, p. 193; pl. 70, figs. 
1-13; tab. 16, fig. 1.3

1995 Assilina yvettae SCHAUB. Tosquella, p. 310; pl. 42, figs. 1-4

1998b Assilina yvettae schaub. Tosquella and SerraKiel, p. 101-102; pl. 18, figs. 1-3

2015 Assilina yvettae SCHAUB. Sirel, pl. 23, figs. 1-12

2018 Assilina yvettae SCHAUB. Sirel, pl. 25, figs. 1-17

Material. Sample from Le Quillet outcrop located in the Petites Pyrénées, see Tambareau (1972, v. 1, p. 53) and Schaub (1991, p 193 and fig. 45); sample Cm 9 from Campo section (Fig. 5); sample Te 6 from Tena section (Fig. 6); samples Urrob 6 and Urrob 7 from Urrobi section (Fig. 8); samples K 1 and K 2 from Korres section (Fig. 13) and sample Er 5 from Aixola-Ermua section (Fig. 14).

Description. Hyaline test with planispiral, evolute coiling. Microspheric forms not found. The morphology of the test is lenticular-flattened with a rounded periphery. The equatorial diameter is $2.7 \mathrm{~mm}$ and the thickness is $1.1 \mathrm{~mm}$ for 4-5 whorls. The spire is regular and closed, assilinoid type, and the marginal cord is thin. The ornamentation is composed of piles over the filaments and at the polar zone. The septa are regularly distributed and straight, slightly curved backward at the top of the chambers. In equatorial section, the outline of the chambers is subrectangular and is higher than wide. The diameter of the proloculus is 100 $150 \mu \mathrm{m}$.

Distribution. This species is identified in Th-2 DS in the following sections: Campo section (Fig. 5); Tena section (Fig. 6); Urrobi section (Fig. 8); Korres section (Fig. 13) and in Aixola-Ermua section (Fig. 14) with the species assemblage indicated in the aforementioned figures. In the Le Quillet outcrop this species is associated with $N$. catari and $A$. azilensis.

Biozone. The stratigraphic data and the associated foraminiofera show that this species belongs to SBZ 4, as pointed out by Schaub (1981) and Serra-Kiel et al. (1998).

\section{Assilina azilensis (TAMBAREAU, 1966) \\ Fig. 25D-I}

1964 Operculina aff. douvillei DONCIEUX. Hottinger, pl. 1, figs. 5a-e, figs. 10-13

1966 Operculina (Nummulitoides) azilensis. Tambareau, p. 301, pl. 1, figs. 1-9

1969 Ranikothalia azilensis (TAMBAREAU). Butterlin and Monod, p. 600; pl. 1, figs. 5, 6 and 9

1977 Operculina azilensis TAMBAREAU. Hottinger, p. 63, text-figs. 22N-S; pl. 23, figs. 1-10

1995 Assilina azilensis (TAMBAREAU). Tosquella, p. 351; pl. 42, figs. $1-5$ 1998b Assilina azilensis (TAMBAREAU). Tosquella and Serra-Kiel, p. 118-119; pl. 23, figs. 7-9

Material. Samples from Cérisols and Le Quillet outcrops located in Petites Pyrénées (France), see Tambareau (1972) and Tambareau et al. (1992b, p.14); sample Cm 9 and $\mathrm{Cm} 10$ from Campo section (Fig. 5); sample Te 6 from Tena section (Fig. 6); samples Urrob 6 and Urrob 7 from Urrobi section (Fig. 8); samples Urb 32 and Urb 33 from Urbasa Pass section (Fig. 11); samples Le 9 and Le 10 from Leortza section (Fig. 12); sample Er 5 from Aixola-Ermua section (Fig. 14).

Description. The tests of the micro- and megalospheric forms show a flattened morphology, slightly inflate at the polar region and have a rounded periphery. The growth is evolute. The microspheric forms show an equatorial diameter of around $5.1 \mathrm{~mm}$ for 5 whorls and a thickness around $0.75 \mathrm{~mm}$ in axial section. The megalospheric forms have an equatorial diameter of around $3.6 \mathrm{~mm}$ for 3 whorls and a thickness around $0.7-1.1 \mathrm{~mm}$ in axial section. In both generations, the spire is regular and opens rapidly. Septa are straight or slightly inclined and curved backward at the top of the chambers. The ornamentation consists of piles concentred at the polar zone. In megalospheric forms, the embryonic apparatus is isolepidine type. The diameter of the protoconch is $190-240 \mu \mathrm{m}$ and the deuteroconch has a length of $170-200 \mu \mathrm{m}$ in axial section and a height of 110 $160 \mu \mathrm{m}$.

Distribution. This species is identified in Th-2 DS in the following sections: Campo section (Fig. 5); Tena section (Fig. 6); Urrobi section (Fig. 8); Urbasa Pass section (Fig. 11); Leortza section (Fig. 12) and in Aixola-Ermua section (Fig. 14) with the species assemblage indicated in the aforementioned figures. In the Cérisols outcrop it is associated with $N$. catari and in the Le Quillet outcrop with $A$. yvettae and $N$. catari.

Biozone. According to the stratigraphic data available and the associated foraminifera, the species belongs to SBZ 4, as pointed out by Hottinger (1977) and Serra-Kiel et al. (1998).

\section{GENUS Ranikothalia CAUDRI Type species: Nummulites nuttalli DAVIES}

\author{
Ranikothalia soldadensis (VAUGHAN AND COLE, \\ 1941) \\ Figs. 25V-B', 26A-M
}

1941 Miscellanea soldadensis. Vaughan and Cole, p. 36; pl. 4, figs. 8-9

1944 Ranikothalia soldadensis (VAUGHAN AND COLE). Caudri, p. 23; pl. 4, fig. 19; pl. 5, figs. 24, 26 ? 


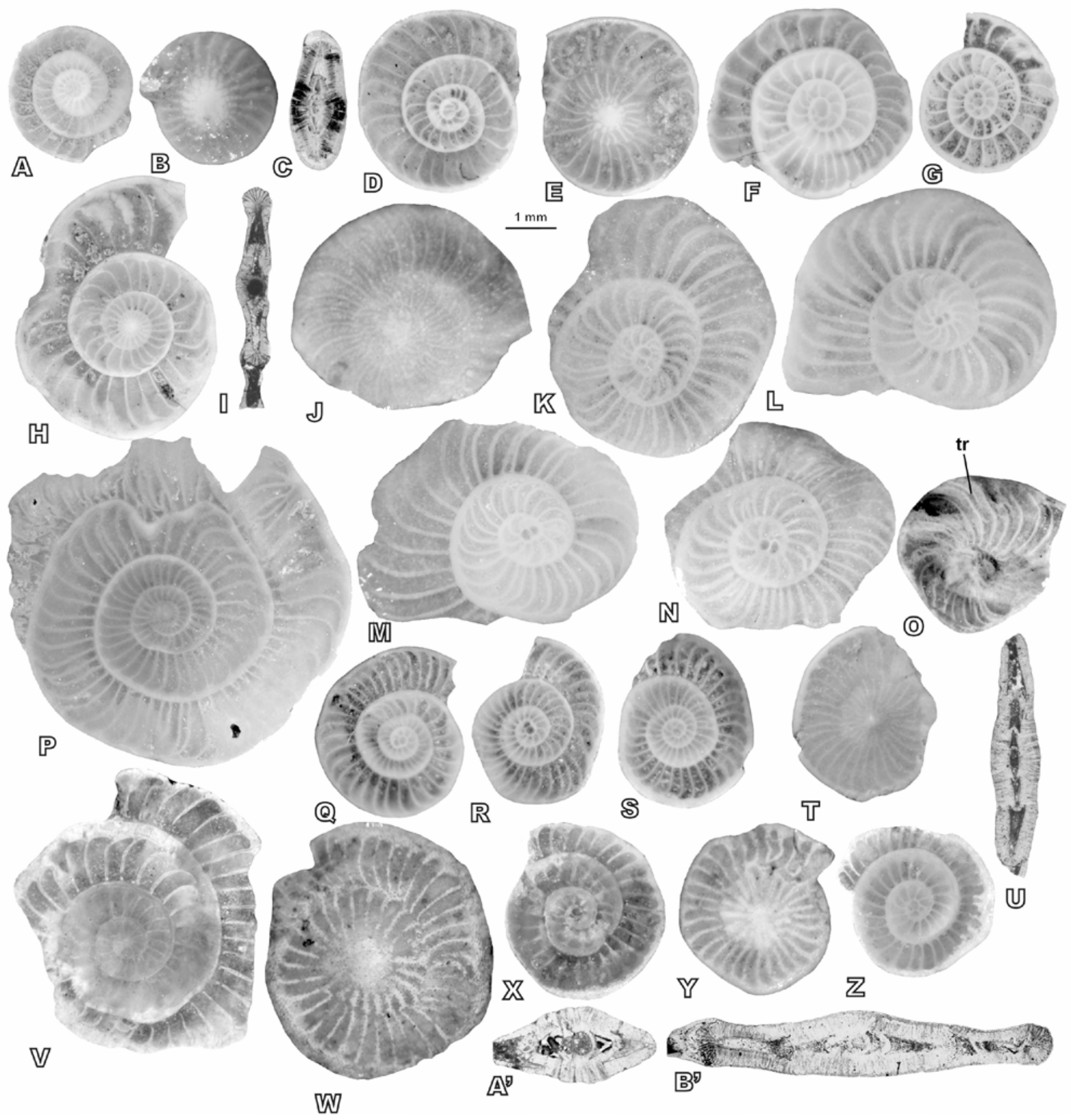

FIGURE 25. Paleocene Larger Foraminifera from the Pyrenean Basin. A-C: Assilina yvettae schauB, 1981, A centered equatorial section; B external view and $\mathbf{C}$ axial section; all specimens megalospheric forms. Specimens A and B from sample Le Quillet outcrop and C from sample K 2. D-I: Assilina azilensis (tambareau, 1966), D, F and $\mathbf{G}$ centered equatorial sections, megalospheric forms; $\mathbf{E}$ external view, megalospheric form; $\mathbf{H}$ centered equatorial section, microspheric form and I axial section. All specimens from sample Cérisols outcrop. J-0: "Operculina" heberti (munIER-chalmas, 1884), J external view, megalospheric form; K-N centered equatorial sections, megalospheric forms; $\mathbf{0}$ oblique equatorial section, megalospheric form, note the trabecular system. Specimens J-N from sample Bouzin outcrop and 15 from Narp outcrop. P-U: Nummulites catari Tosquella AND SERRA-KIEL, 1998, $\mathbf{P}$ centered equatorial section, microspheric form; Q-S centered equatorial sections, megalospheric forms; $\mathbf{T}$ external view, megalospheric form and U axial section, megalospheric form. All specimens from sample from Cérisols outcrop. V-B': Ranikothalia soldadensis (vaUGHAN AND CoLE, 1941), V equatorial section, microspheric form; $\mathbf{W}$ external view, microspheric section; $\mathbf{X}$ and $\mathbf{Z}$ centered equatorial sections, megalospheric forms; $\mathbf{Y}$ external view, megalospheric form; A' centered axial section, megalospheric form; B' axial section, microspheric form. Specimens V-Z from sample Ruisseau de la Mède outcrop; A' from sample Aix 14 and B' from Er 1. Abbreviations: tr: trabecular system 
1945 Miscellanea soldadensis (VAUGHAN AND COLE). Vaughan, p. 30; pl. 5, figs. 2-5

1960 Operculina catenula (CUSHMAN AND JARVIS). Butterlin and Bonet, p. 11-14; pl. 2, figs. 1-5

1975 Ranikothalia soldadensis (VAUGHAN AND COLE). Caudri, p. 539; pl. 1, figs. 1, 4; pl. 2, figs. 1, 6, 8; pl. 6, figs. 1,3 ; pl. 7, figs. $1-5$, pl. 8, figs. 1-3

1996 Ranikothalia soldadensis (VAUGHAN AND COLE). Caudri, p. 1185; pl. 5.4; pl. 9.1

1997 Ranikothalia soldadensis (VAUGHAN AND COLE). Berlanga, p. 145-151; pl. 30, figs. 1-4; pl. 31, figs. 1-3; pl. 32, figs. 1-6; pl. 33, fig. 1

2014 Ranikothalia soldadensis (VAUGHAN AND COLE). Vicedo et al., p. 58-62; figs.14-16

Material. Sample from Ruisseau de la Mède outcrop located in Plantaurel region, north Pyrenean realm, see Villatte (1962) and Tambareau (1972); samples Urb 26 and Urb 28 from Urbasa Pass section (Fig. 11) and samples Aix 13, Aix 14 and Er 1 from Aixola-Ermua section (Fig. 14).

Description. The microspheric forms show a flat morphology. The equatorial diameter is around $7.2 \mathrm{~mm}$ and the axial thickness is around $1.3 \mathrm{~mm}$ for 4 whorls. The megalospheric forms show a lenticular-flattened morphology with rounded periphery. In both generations, the growth is involute, becoming evolute in the last whorls. The ornamentation is composed of septal filaments and large piles at the polar zone. The septa are slightly curved. The marginal cord is thick. The proloculus in megalospheric forms has a diameter varying from 150 to $180 \mu \mathrm{m}$.

Remarks. Comparison of specimens of $R$. sindensis from the Paleocene of the Salt Range (Pakistan), those described here (Fig. 26P-Q) and those from Libya illustrated by Hottinger (1977), show that Ranikothalia sindensis differs from Ranikothalia soldadensis in the larger shell dimensions, the looser spiral, the larger diameter of the proloculus and the thinner marginal cord. Inconsistences related to genus Ranikothalia are discussed in more detail in Vicedo et al. (2014).

Distribution. This species is identified in Se/Th-1 DS in the following section: Urbasa Pass section (Fig. 11) and in Aixola-Ermua section (Fig. 14) where, in the the pebbles taken from a breccia in Th-2 DS, this species is associated with the species assemblage indicated in the aforementioned figures.

Biozone. According the stratigraphic data and the associated foraminifera this species belongs to SBZ 3, as pointed out by Tosquella (1995) and Serra-Kiel et al. (1998).

\section{Family Discocyclinidae GALLOWAY GENUS: Discocyclina GbMBEL Type species: Orbitolites pratti MICHELIN}

\section{Discocyclina seunesi DOUVILLE, 1922 Fig. 27A-B}

1972 Discocyclina seunesi DouviLLE. Neumann, pl. 4; fig. 8

1972 Discocyclina seunesi DouviLle. Samuel et al., p. 159; figs. 1-7.

1987 Orbitocypeus seunesi (DOUVILLE). Less, p. 194196; text-fig. 30a

2009 Discocyclina seunesi DouviLlé. Sirel, pl. 4, fig. 5

Material. Sample Te 2 from Tena section (Fig. 6); sample Urrob 4 from Urrobi section (Fig. 8); samples An 1, An 2, An 5, An 9 and An 11 from Andia section (Fig. 9); samples L 24, L 25 and L 26 from Lizarraga section (Fig. 10); samples Urb 23, Urb 24, Urb 25 and Urb 27 from Urbasa Pass section (Fig. 11) and sample Le 3 from Leortza section (Fig. 12).

Description. Small, lamellar perforate test with lenticular morphology. The equatorial diameter is about $1 \mathrm{~mm}$ for $30-35$ annuli and the thickness about $0.3 \mathrm{~mm}$. The embryonic apparatus is composed of a small protoconch and a deuteroconch. The diameter of the protoconch is around $0.1 \mathrm{~mm}$. The equatorial chambers increase in size towards the periphery.

Distribution. This species is present in Se/Th-1 DS in the following sections: Tena section (Fig. 6); Urrobi section (Fig. 8); Andia section (Fig. 9); Lizarraga section (Fig. 10); Urbasa Pass section (Fig. 11)and in Leortza section (Fig. 12) with the species assemblage indicated in the aforementioned figures.

Biozone. According to Less (1987) this species is probably Thanetian in age. Later, Less in Serra-Kiel et al. (1998) stablished its biostratigraphic range as SBZ 3. Our data confirm this attribution.

\section{Family Pararotaliidae REISS}

Description. Hyaline, trochospiral shells with single or multiple foramina and a "toothplate" as umbilical closure of the spiral chamber, with or without a dense enveloping canal system.

Remarks. This definition of the family is in agreement with Hottinger's (2014) point of view that some rotaliform morphotypes, particularly the representatives of subfamilies Pararotaliinae REISS, 1963 and Laffiteininae HOTTINGER, 2014 (=Cuvillierininae LOEBLICH AND TAPPAN, 1964) should be excluded from from the Family Rotaliidae. However Hottinger (2014) in his "Identification Key to Some Genera Excluded from the Rotaliacea" also proposed to exclude them from the superfamily Rotalioidea EHRENBERG, a 
view that we have not followed here, taking into account the definition of this taxon given by Loeblich and Tappan (1987). In consequence the former subfamily Pararotaliinae is elevated here to the rank of Family Pararotaliidae.

Subfamily Pararotaliinae REISS

GENUS Paralockhartia HOTTINGER

Type species: Paralockhartia eos, HOTTINGER
Paralockhartia eos HOTTINGER, 2014

Fig. 27C-D

2014 Paralockhartia eos. Hottinger, p. 157; pl. 8.3, figs. 1-14; pl. 8.4, figs. 1-15

Material. Sample L 3 from Lizarraga section (Fig. 10) and sample Ur 18 from Urko section (Fig. 15).
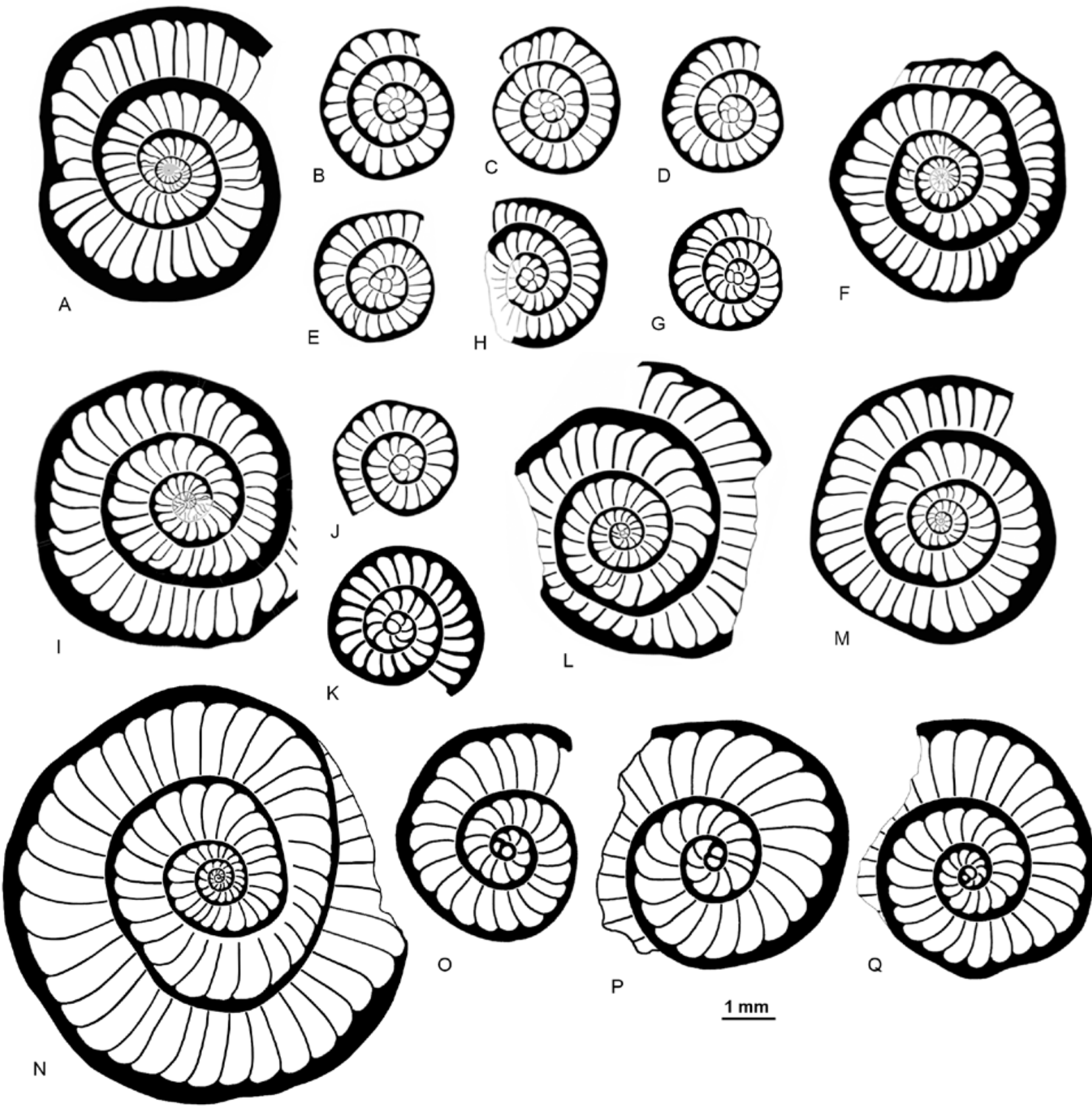

$\underline{1 \mathrm{~mm}}$

FIGURE 26. Paleocene Larger Foraminifera from the Pyrenean Basin. A-M: Ranikothalia soldadensis (vaughan and cole, 1941) A-E Specimens from Campeche drawings after Berlanga (1997); F-G Specimens from Dor M'Said drawings after Hottinger (1977). H-I Specimens from Ruisseau de la Mède drawings after Hottinger (1997). J-M Specimens from Ruisseau de la Mède drawings after our material. N-Q: Ranikothalia sindensis (DAvieS, 1927), specimens from Salt Range (Pakistan) drawings after our material. 
Description. The test is bilamellar perforate with trochospiral growth and lenticular morphology. The dorsal and ventral sides have similar convexities. The equatorial diameter is around $1.2 \mathrm{~mm}$ for three whorls. The ventral side shows piles and discontinuous funnels. The proloculus has a diameter of around $60 \mu \mathrm{m}$.

Distribution. This species is found in Da-2 DS in the following sections: Lizarraga section (Fig. 10) and in Urko section (Fig. 15) with the species assemblage indicated in the aforementioned figures.

Biozone. The stratigraphic data and the associated taxa presented here validate the attribution of this species to SBZ 2 as proposed by Hottinger (2014).

\section{Subfamily Cuvillierininae LOEBLICH AND TAPPAN}

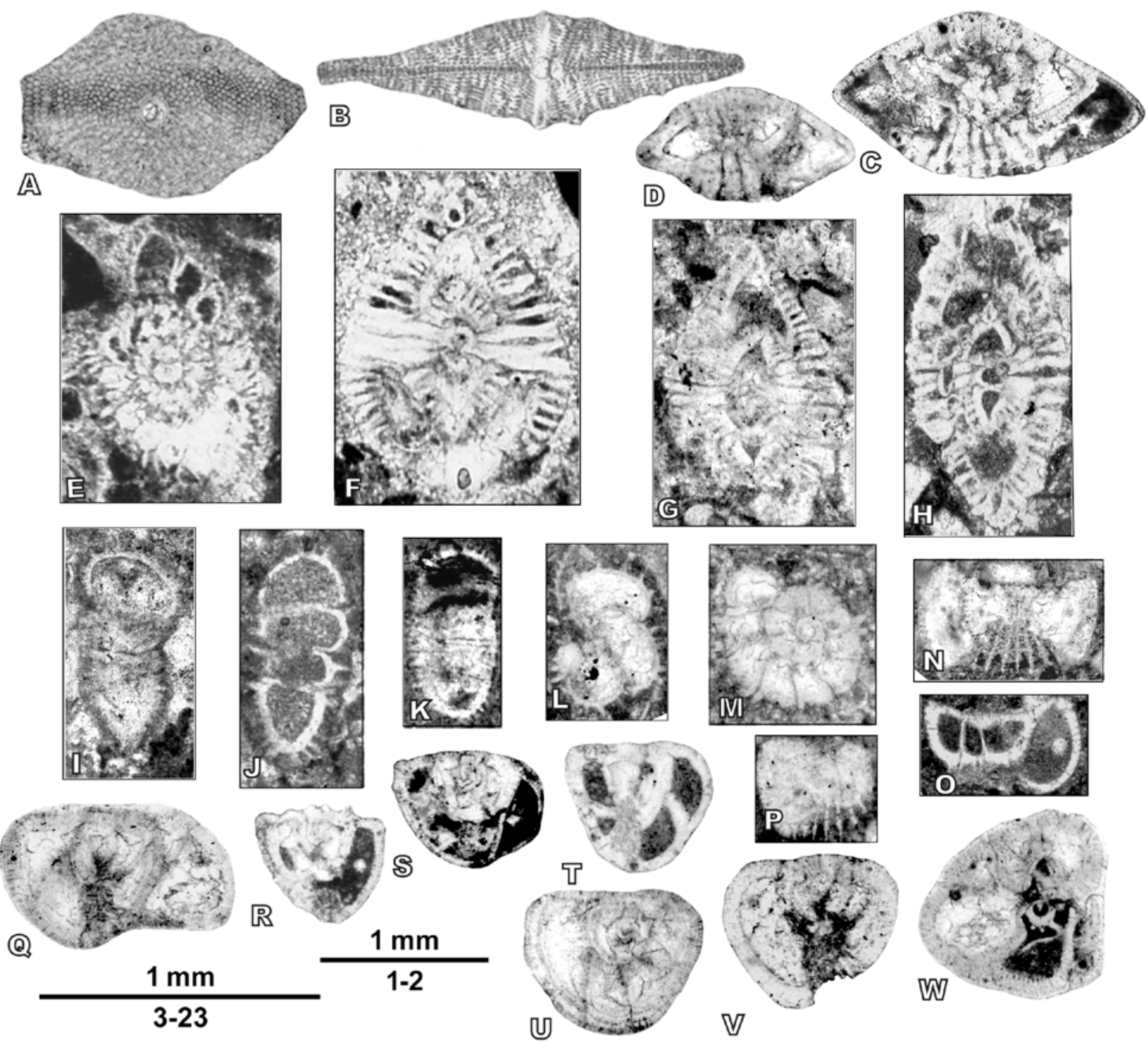

FIGURE 27. Paleocene Larger Foraminifera from the Pyrenean Basin. A-B: Discocyclina seunesi douvilLE, 1922. A centred equatorial section; B axial section. Specimens A and B from sample An 1. C-D: Paralockhartia eos HotTInger, 2014 axial sections. Specimen C from sample L 3 and D from sample Ur 18. E-H: Cuvillierina sireli InAN, 1988; $\mathbf{E}$ oblique equatorial section; $\mathbf{F}$ centered axial section; $\mathbf{G}$ and $\mathbf{H}$ subaxial sections. Specimen $\mathbf{E}$ and F from sample Urb 26; G from sample Tap 10 and H from sample G 3. I-M: Thalmannita madrugaensis (cusHMAN AND BERMÚdEz, 1947). I-K subaxial sections; $\mathbf{L}$ subequatorial section and $\mathbf{M}$ centered equatorial section. Specimen I from sample Aix 12; J from sample Le 5; K from sample Urb 25; L from sample Urrob 3; M from sample Bur 3. N-P: Scarificatina reinholdi (PozARYsKa AND szczechuRA, 1970). $\mathbf{N}$ axial section; $\mathbf{0}$ and $\mathbf{P}$ subaxial sections. Specimen N from sample L 12; O from sample Ur 10 and P from sample L 19. Q-W: Cincoriola ovoidea (HAQUE, 1958). Q-V axial sections; W oblique section. Specimens $Q, R, U$ and $W$ from sample $\mathrm{Cm} 5$; $\mathrm{S}$ and $\mathrm{T}$ from sample $\mathrm{Cm} 3$ and $\mathrm{V}$ from sample Beo 2. 
The subfamily Laffitteininae introduced by Hottinger (2014) is a junior synonym of Cuvillierininae LOEBLICH AND TAPPAN, 1964. As stated by Hottinger (2014, p. 153) "This group merits to be ranked as a particular subfamily Cuvillierininae LOEBLICH AND TAPPAN, 1964”.

\section{Genus Cuvillierina DEBOURLE}

Type species: Laffitteina vallensis, RUIZ DE GAONA

\section{Cuvillierina sireli INAN, 1988 \\ Fig. 27E-H}

1988 Cuvillierina sireli. Inan, p. 121; pl. 1, figs.1-9; pl. 2, figs. 1-8

1998 Pseudocuvillierina sireli (INAN). Sirel, p. 86; pl. 44, figs. $1-20$

2004 Pseudocuvillierina sireli (INAN). Sirel, p. 9; pl. 7, figs. $1-20$

2000 "Cuvillierina" sireli INAN. Peybernès et al., p. 46; figs. 6.11-6.3

2009 Pseudocuvillierina sireli (INAN). Sirel, pl. 3, figs. 9-13

2014 Cuvillierina sireli INAN. Hottinger, p. 164, 166; pl. 8.7, figs. 1-11; pl. 8.8, figs. 1-12

2008 Pseudocuvillierina sireli (INAN). Pignatti et al., pl. 6, fig. 11

2010 Pseudocuvillierina sireli (INAN). Di Carlo et al., p. 70 ; pl. 1, fig. 12

2015 Pseudocuvillierina sireli (INAN). Sirel, pl. 7, figs. $1-21$

2018 Pseudocuvillierina sireli (INAN). Sirel, pl. 21, figs. 1-21

Material. sample G 3 from Garralda section (Fig, 7); sample Urb 26 from Urbasa Pass section (Fig. 11); samples Le 4 and Le 5 from Leortza section (Fig. 12); samples Er 1, Er 2 and Er 3 from Aixola-Ermua section (Fig. 14); sample Ur 14 and Ur 17 from Urko section (Fig. 15) and sample Tap 10 from Tapla section (Robador, 2005, Annex, p. 48-49).

Description. The test is lenticular with a bilamellar perforate wall. The chamber arrangement is very lowtrochospiral, almost planispiral. The enveloping canal system covers both sides of the test (Fig. 27G). The periphery is acute. Both umbos are perforated by funnels. The equatorial diameter varies from 1.15 to $1.2 \mathrm{~mm}$ and the thickness from 0.7 to $0.8 \mathrm{~mm}$ with two whorls. The diameter of the proloculus is about $90 \mu \mathrm{m}$.

Distribution. This species is identified in the following Depositional Sequences: Da-2 DS from Urko section (Fig. 15). Se/Th-1 DS from Garralda section (Fig. 7); Urbasa Pass section (Fig. 11); Leortza section (Fig. 12) and in Aixola-Ermua section (Fig. 14) in two pebbles of the breccia located in Th-2 DS with the species assemblage indicated in the aforementioned figures.

Biozone. According to Sirel (1998), the age of this species is Thanetian. Serra-Kiel et al. (1998) considered its biostratigraphic as ranging from SBZ 2 to the middle part SBZ 4. The biostratigraphic range of this species from the middle part SBZ 5 to middle part SBZ 9 illustrated in figure 3.1 of Hottinger (2014) is certainly a mistake introduced while finishing this book after the author's decease. In the study area this species has been found to range from the middle part of the SBZ 2 to SBZ 3.

\section{Rotaliid taxa of uncertain affinities sensu Hottinger (2014) Genus Thalmannita BERMbDEZ \\ Type species: Rotalia madrugaensis, CUSHMAN AND BERMЪDEZ}

\section{Thalmannita madrugaensis (CUSHMAN AND BERMЪDEZ, 1947) \\ Figs. 27I-27M}

2000 Thalmannita madrugaensis (CUSHMAN AND BERMÚDEZ), Peybernès et al., p. 46; fig. 4b

2009 Thalmannita madrugaensis (CUSHMAN AND BERMÚDEZ). Sirel, pl. 1, figs. 1-7

2014 Thalmannita madrugaensis (CUSHMAN AND BERMÚDEZ). Hottinger, p. 173, 176; pl. 9.1, figs. 1-21

2018 Thalmannita madrugaensis (CUSHMAN AND BERMÚDEZ). Sirel, pl. 7, figs. 15-22

Material. Sample Te 5 from Tena section (Fig. 5); sample Urrob 5 from Urrobi section (Fig. 8); sample Urb 25 from Urbasa Pass section (Fig. 11); samples Le 5 and Le 8 from Leortza section (Fig. 12); samples Aix 12, Aix 18, Aix 21, Er 1 and Er 2 from Aixola-Ermua section (Fig. 14); sample Bur 3 from Burgi section (Robador, 2005, Annex, pp. 78-79) and Orio 3 sample from a pebble taken from Orio section (p. 248, fig. 75, Baceta, 1996).

Description. Bilamellar perforate test with planispiral growth. The chambers are inflated and the periphery of the shell is rounded. The ornamentation is formed by abundant spines. The equatorial diameter is around $0.6 \mathrm{~mm}$.

Distribution. This species is identified in $\mathrm{Se} / \mathrm{Th}-1 \mathrm{DS}$ in the following sections: Tena section (Fig. 5); Urrobi section (Fig. 8); Urbasa Pass section (Fig. 11); Leortza section (Fig. 12) and in Aixola-Ermua section (Fig. 14) and in two pebbles collected in the breccia in DS Th-2 this species is associated with the species assemblage indicated in the aforementioned figures.

Biozone. According to Serra-Kiel et al. (1998) and Hottinger (2014), the biostratigraphic range of this species extends from SBZ 3 to SBZ 4. 
GENUS Scarificatina MOORKENS

Type species: Boldia reinholdi, POZARYSKA AND SZCZECHURA

\author{
Scarificatina reinholdi (POZARYSKA AND \\ SZCZECHURA, 1970) \\ Fig. 27N-P
}

2000 Scarificatina sp., Peybernès et al. p. 46; fig. 6.9 2012 Haymanina danica. Sirel, p. 274; pl. 1, figs. 1-3 2014 Scarificatina reinholdi (POZARYSKA AND SZCZECHURA). Hottinger, p. 181; pl. 9.3

2015 Haymanina danica. Sirel, pl. 1, figs. 1-3

Material. Samples L 12 and L 19 from Lizarraga section (Fig. 10); samples Urb 7, Urb 13 from Urbasa Pass section (Fig. 11); sample Aix 6 from Aixola-Ermua section (Fig. 14) and samples Ur 10, Ur 11 and Ur 14 from Urko section (Fig. 15).

Description. The test is bilamellar perforate with planispiral growth and non-symmetric equatorial morphology. The equatorial diameter varies from 0.5 to $0.6 \mathrm{~mm}$. The wall shows coarse pores. The dorsal side is flattened to slightly concave. The ventral side has parallel crests. The diameter of the proloculus is around $60 \mu \mathrm{m}$.

Distribution. This species is present in the following Depositional Sequences: Da-1 DS from Urbasa Pass section (Fig. 11); Aixola-Ermua section (Fig. 14 and in Urko section (Fig. 15). Da-2 DS from Lizarraga section (Fig. 10); Urbasa Pass section (Fig. 11) and in Urko section (Fig. 15) with the species assemblage indicated in the aforementioned figures.

Biozone. According to Hottinger (2014) the biostratigraphic range of this species extends from the upper part of SBZ 2 to SBZ 5.

\section{GENUS Cincoriola HAQUE Type species: Punjabia ovoidea}

\section{Cincoriola ovoidea (HAQUE, 1956) Fig. 27Q-W}

1998? Kathina melona (RAHAGHI). Accordi et al., p. 174; pl. 3, fig. 3.c; p. 196; pl. 14, figs. 1-3

1998 Soriella cf. bitlisica SIREL. Accordi et al., p. 190; pl. 11 , fig. 1

2014 Cincoriola ovoidea (HAQUE). Hottinger, p. 183; pl. 9.4, figs. 14-23; pl. 9.5; 1-14

2018 Soriella bitlisica SIREL. Sirel, pl. 7, figs. 7-14

2018 Cincoriella paleocenica. Sirel, pl. 10, figs. 12-14
Material. Samples $\mathrm{Cm} 3$ and $\mathrm{Cm} 5$ from Campo section (Fig. 5) and Sample Beo 2 from Beoburu section (Robador, 2005, Annex, p. 112).

Description. Lamellar perforate test with subglobular morphology and trochospiral growth. The diameter of the proloculus is around $0.05 \mathrm{~mm}$. The dorsal side is flattened, the ventral side is markedly convex with rounded outline. For two whorls the equatorial diameter is around $0.6 \mathrm{~mm}$ $0.7 \mathrm{~mm}$.

Distribution. This species is present in Campo section (Fig. 5) in Se/Th-1 DS with the species assemblage indicated in the aforementioned figures.

Biozone. The data obtained in this study validate the belonging of this species to the SBZ 3, as pointed out by Hottinger (2014).

\section{Biostratigraphy based on Larger Foraminifera}

Sixty species of larger foraminifera were found in the Pyrenean Paleocene with a biostratigraphic distribution belonging to the Tethyan SBZ 1 to SBZ 4. The new data led to a revision of the definition of these biozones, as proposed below.

Remarks on SBZ 1. According Serra Kiel et al. (1998), this biozone is characterized by the presence of Laffitteina bibensis and Bangiana hanseni as taxa defining the beginning of the Danian stage. According to our database, the use of these two species as markers need emendation.

Laffitteina bibensis is found in the Campo section together with the charophytes Peckichara llobregatensis and Sphaerochara edda attributed to the base of Paleocene (Fig. 5). Marie (1946) characterized these species from the Mont Aimé marls (Paris Basin) as being of Montian age. Later, Bignot (1987), Bignot (1993) and Bignot et al. (1997) also attributed the Vertus-Mont Aimé Fm. with Laffitteina bibensis (type locality) to the early Danian. However, the Paleocene age of the beds containing Laffitteina bibensis in Campo (sample Cm 1, Fig. 5) was first questioned by López-Martínez et al. (2006), who pointed out that these deposits underlie beds with rudists, the ammonite Pachydiscus gollevillensis and dinosaur remains. Finally, Guernet and Villier (2017), while studying the ostracods associated with - in the Mont Aimé Fm., considered that they were exclusively Cretaceous in age. Altogether, these data indicate that the attribution of the Laffitteina bibensis to the Danian should be rejected.

Bangiana hanseni was first described by Drobne et al. (2007) from the Danian of Slovenia. In the Pyrenees, this 
species has been identified in the sections of Tena (sample Te 1; Fig. 6), Urrobi (samples Urrob 1 and Urrob 2; Fig. 8) and Urbasa Pass (samples Urb 2, Urb 12, Urb 16 and Urb 21; Fig. 11). In the Tena and Urrobi sections, this species is located in the Da-1 DS, while in the Urbasa section (Fig. $11)$, it is located in the Ma-Da Ds and Da-2 DS. In the Ma-Da DS Bangiana hanseni occurs associated with P.? antiqua, and Stomatorbina? binkhorsti, whereas in the Da-2 DS it is associated with Haymanella paleocenica, Haymanella elongata and Goesella sp. and overlying the beds with Miscellanites globularis and Ornatononion moorkensii indicating an SBZ 2 age.

In the Urbasa Pass section, other species found in the lower and middle parts of the Danian, Ma-Da DS and Da-1 DS, are Valvulineria patalaensis associated with P.? antiqua, P.? cretae and Stomatorbina? binkhorsti (samples Urb 1, Urb 2, Urb 3 and Urb 4; Fig. 11). It is important to remark that Planorbulina? antiqua is located in our material in the stratigraphic interval belonging to the SBZ 1 (Urbasa Pass section, samples Urb 1, Urb 2 and Urb 3; Fig. 11) and in the lower part of the SBZ 2 (Urko section, sample Ur 4; Fig. 15).

In sum, Laffitteina bibensis is an exclusively Cretaceous species while the association of Bangiana hanseni, Miscellanites globularis and Ornatononion moorkensii does not allow anymore to propose the former species as exclusive of SBZ 1. This zone is thus characterized by the absence of the true larger foraminifera. Even the small foraminifera, such as $P$.? antiqua, Valvulineria patalaensis and S.? binkhorsti are not exclusive of this zone.

Remarks on SBZ 2. Serra Kiel et al. (1998) characterized biozone SBZ 2 based on the assemblage formed by Miscellanea globularis, Ornatononion minutus, Paralockhartia eos and Lockhartia akbari. However, according to Hottinger (2009) Miscellanea globularis has a biostratigraphic range encompassing SBZ 2 and SBZ 3, a fact that rules it out as a marker for SBZ 2. In turn, the species identified as Ornatononion minutus by Serra-Kiel et al. (1998) and combined as Miscellanea minuta by Rahaghi (1983; pl. 43, figs. 6-11) would be restricted to SBZ 3 according to Hottinger (2009), excluding it from SBZ 2. Moreover, Paralockhartia eos would have a biostratigraphic range restricted to SBZ 2 according to Hottinger (2014). Other larger foraminifera found in the material studied and belonging to SBZ 2 shed new light on the assemblage characteristic of this biozone:

Elazigina dienii (=Plumokathina dienii), attributed exclusively to SBZ 2 by Hottinger (2014), has been found associated with Miscellanites globularis in Garralda section (sample G 2; Fig. 7), with Haymanella elongata, Rotorbinella conica, Daviesina praegarumnensis and
Paralockhartia eos in Lizarraga section (Fig. 10), with Miscellanites globularis, Stomatorbina? binkhorsti, Redmondina henningtoni and Valvulineria patalaensis in Aixola-Ermua section (Fig. 14) and with M. globularis and Ornatononion moorkensii in Urko section (Fig. 15). These results confirm the exclusive attribution of $E$. dienii to SBZ 2.

Also, Ornatononion moorkensii is confirmed to be restricted to the SBZ 2 as indicated by Hottinger (2014). This species has been found associated with Haymanella elongata, Scarificatina reinholdi and Planorbulina? cretae in Lizarraga section (Fig. 10), with Rotorbinella hensoni, Rotorbinella skourensis, Planorbulina? cretae, Pyrenerotalia depressa, Kathina aquitanica, Elazigina dienii, Stomatorbina? binkhorsti, Miscellanites globularis, Cuvillierina sireli, Paralockhartia eos and Scarificatina reinholdi in Urko section (Fig. 15).

Paralockhartia eos, attributed to the SBZ 2 by Hottinger (2014), is also confirmed as a marker of SBZ 2 as it has been found associated with Haymanella elongata, Rotorbinella conica and Elazigina dienii in the Lizarraga section (Fig. 10) and in the Urko section (Fig. 15). Also Rotospirella conica belongs exclusively to the SBZ 2 and has been found associated with Haymanella elongata, Elazigina dienii, Daviesina praegarumnensis and Paralockhartia eos in the Lizarraga section (Fig. 10). The same situation is that of Pyrenerotalia depressa, which has been found exclusively in rocks attributed to the SBZ 2 in Urko section (Fig. 15) along with Rotorbinella hensoni, Rotorbinella skourensis and Ornatononion moorkensii.

On the other hand, some other associated species can no longer be considered as characteristic of SBZ2. Thus, Daviesina praegarumnensis extends from SBZ 2 to SBZ 3 according to (Hottinger, 2014), and it has been found indeed in beds attributed to the SBZ 2 in Lizarraga section (sample 3; Fig. 10) while in Campo section (samples Cm 3 and $\mathrm{Cm}$ 6; Fig. 5) it reaches the SBZ 3.

Other taxa that we found within the interval characterized as SBZ 2 are Kayseriella decastroi associated with Haymanella paleocenica, Haymanella elongata, Scarificatina reinholdi, Stomatorbina? binkhorsti and Miscellanites globularis in Urbasa Pass section (Fig. 11), associated with Miscellanites globularis (Fig. 10) and Valvulineria patalaensis along with Scarificatina reinholdi in Lizarraga section (Fig. 10) and with Rotorbinella hensoni, Rotorbinella skourensis and Scarificatina reinholdi in the Monte Urko section (Fig. 15). Finally, Goesella sp. is present in the Urbasa Pass section (Fig. 11) associated with Haymanella paleocenica, H. elongata and Bangiana hanseni. 
In sum, the new assemblage of species proposed as markers for SBZ 2 is formed by Elazigina dienii, Haymanella elongata, Haymanella paleocenica, Kayseriella decastroi, Ornatononion moorkensii, Pyrenerotalia depressa, Rotorbinella conica and Paralockhartia eos.

Remarks on SBZ 3. Serra-Kiel et al. (1998) characterized the SBZ 3 with the assemblage formed by Glomalveolina primaeva, Periloculina slovenica, Coskinon rajkae, Fallotella alavensis, Cribrobulimina carniolica, Vania anatolica, Miscellanea yvettae, Pseudomiscellanea primitiva, Ranikothalia bermudezi, "Operculina" heberti and Discocyclina seunesi. The data obtained here indicate that this assemblage shoul be modified in order to characterize properly the SBZ 3 as follows.

- Glomalveolina primaeva, was found in the sections of Serraduy (Fig. 4), Campo (Fig. 5), Tena (Fig. 6), Andia (Fig. 9), Lizarraga (Fig. 10), Urbasa Pass (Fig. 11), Leortza (Fig. 12) and Aixola-Ermua (Fig. 14).

- Periloculina slovenica is present in the sections of Campo (Fig. 5), Tena (Fig. 6), Andia (Fig. 9), Lizarraga (Fig. 10) and Leortza (Fig. 12).

- Coskinon rajkae is present in Campo section (Fig. 5), Tena section (Fig. 6), Andia section (Fig. 9), Lizarraga section (Fig. 10) and Leortza section (Fig. 12).

- Fallotella alavensis is present in the sections of Campo (Fig. 5), Tena (Fig. 6), Leortza (Fig. 12) and AixolaErmua (Fig. 14).

- Cribrobulimina carniolica occurs in the sections of Serraduy (Fig. 4), Campo (Fig. 5), Tena (Fig. 6) and Leortza (Fig. 12).

- Vania anatolica occurs in Campo section (Fig. 5), Tena section (Fig. 6) and Leortza section (Fig. 12).

- $\quad$ Miscellanea yvettae is present in Campo section (Fig. 5), Garralda section (Fig. 7) and Leortza section (Fig. 12).

- Miscellanea juliettae is present in Urbasa Pass (Fig. 11) and the Leortza section (Fig. 12).

- $\quad$ Miscellanites primitivus (=Pseudomiscellanea primitiva), was found in the sections of Garralda (Fig. 7), Andia (Fig. 9), Lizarraga (Fig. 10) and Urbasa Pass (Fig. 11).

- Miscellanites minimus is present in Garralda section (Fig. 7).

- "Operculina" heberti is a relatively common taxon found in Tena section (Fig. 6), Urrobi section (Fig. 8), Andia section (Fig. 9), Lizarraga section (Fig. 10), Urbasa Pass (Fig. 11), Leortza section (Fig. 12), Aixola-Ermua section (Fig. 14) and the Bouzin outcrop.

- Discocyclina seunesi is present in the Tena section (Fig. 6), the Urrobi section (Fig. 8), the Andia section (Fig. 9), the Lizarraga section (Fig. 10), the
Urbasa Pass section (Fig. 11) and the Leortza section (Fig. 12).

- $\quad$ Ranikothalia soldadensis occurs in Urbasa Pass (Fig. 11) and the Ruisseau de la Mède outcrop.

Other characteristic species located within the SBZ 3 interval are:

- Idalina sinjarica, found in the sections of Serraduy (Fig. 4), Campo (Fig. 5), Tena (Fig. 6), Lizarraga (Fig. 10) and Leortza (Fig. 12).

- Pseudolacazina donatae, present in Campo (Fig. 5), Tena (Fig. 6) and Leortza (Fig. 12).

- Cuvillierina sireli, in Garralda (Fig. 7), Urbasa pass (Fig. 11) and Leortza (Fig. 12).

- $\quad$ Scarificatina reinholdi, only present in Lizarraga (Fig. 10).

- Redmondina henningtoni, in Campo (Fig. 5), Tena (Fig. 6), Leortza (Fig. 12) and Aixola-Ermua (Fig. 14).

- Elazigina lenticula, found in Aixola-Ermua (Fig. 14), Andia (Fig. 9) and Lizarraga pass (Fig. 10).

- Cincoriola ovoidea, present in Campo (Fig. 5).

- Kathina aquitanica, present in the sections of Serraduy (Fig. 4), Campo (Fig. 5), Garralda (Fig. 7) and Andia (Fig. 9).

- Kathina pernavuti was only found in the Campo section (Fig. 5).

- $\quad$ Thalmannita madrugaensis, is present in Tena section (Fig. 6), Urrobi section (Fig. 8), Urbasa Pass section (Fig. 11), Leortza section (Fig. 12) and AixolaErmua (Fig. 14).

- Daviesina praegarumnensis, occurs in Campo section (Fig. 5).

- Valvulineria bacetai n. sp., is present in Campo (Fig. 5), Lizarraga pass (Fig. 10) and Urbasa Pass (Fig. 11).

It should be noted that, according to Hottinger (2014), the biostratigraphic ranges of Kathina lenticula, Thalmannita madrugaensis and Redmondina henningtoni are from SBZ 3 to SBZ8, from SBZ 3 to SBZ 4 and from SBZ 3 to SBZ 6 respectively.

In sum, the new assemblage proposed to characterize SBZ 3 is formed by Glomalveolina primaeva, Periloculina slovenica, Vania anatolica, Coskinon rajkae, Fallotella alavensis, Cribrobulimina carniolica, Miscellanea yvettae, Miscellanea juliettae, Miscellanites primitivus, Miscellanites minutus, Ranikothalia soldadensis, "Operculina" heberti and Discocyclina seunesi.

Remarks on SBZ 4. Serra-Kiel et al. (1998) characterized SBZ 4 biozone with the assemblage formed by Glomalveolina levis, Hottingerina lukasi, Miscellanea meandrina, Daviesina garumnensis, Dictyokathina simplex, Nummulites catari, Assilina azilensis and 


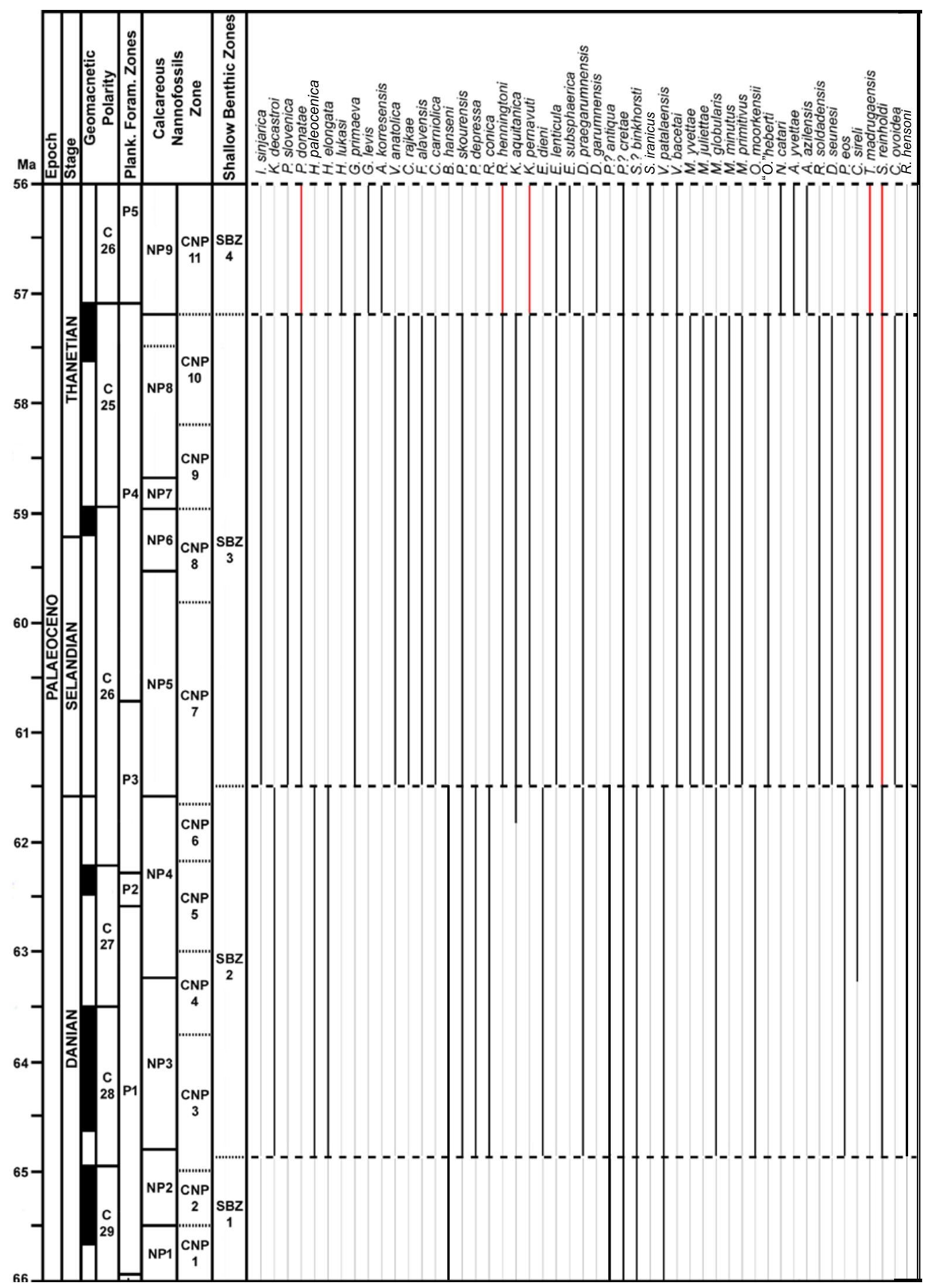

FIGURE 28.Paleocene larger foraminifera distribution. The range shown with a red line is in accordance with the indications of previous authors. 
Assilina yvettae. It should be noted that, after Hottinger (2009), Miscellanea meandrina has been combined as Miscellanites meandrinus. The proposal of combining this species within genus Diyadinella by Sirel (2018) is not well documented from our point of view.

According to the stratigraphic distribution of larger foraminifera in this work, the SBZ 3 biozone is characterized by the presence of following markers:

- $\quad$ Glomalveolina levis, in Serraduy section (Fig. 4), in Campo section (Fig. 5), in Tena section (Fig. 6), in Korres section (Fig. 13).

- $\quad$ Alveolina korresensis, in Korres section (Fig. 13)

- Hottingerina lukasi, in Korres section (Fig. 13).

- Daviesina garumnensis, in Serraduy section (Fig. 4), in Campo section (Fig. 5), in Korres section (Fig. 13), in Aixola-Ermua section (Fig. 14) and samples from Le Quillet and Cérisols outcrops.

- Assilina yvettae, in Campo section (Fig. 5), in Tena section (Fig. 6), in Urrobi section (Fig. 8), in in Korres section (Fig. 13), in Aixola-Ermua section (Fig. 14) and sample from Le Quillet outcrop.

- Assilina azilensis, in Campo section (Fig. 5), in Tena section (Fig. 6), in Urrobi section (Fig. 8), in Urbasa Pass section (Fig. 11), in Leortza section (Fig. 12), in Aixola-Ermua section (Fig. 14) and samples from Cérisols and Le Quillet outcrops.

- Nummulites catari, samples from Cérisols and Le Quillet outcrops.

Other species located within the interval characterized as SBZ 4 we found:

- $\quad$ Elazigina lenticula in Korres section (Fig. 13), in Aixola-Ermua section (Fig. 14).

- Elazigina subsphaerica, in Aixola-Ermua section (Fig. 14).

- Valvulineria bacetai n. sp., in Korres section (Fig. 13).

- $\quad$ Redmondina henningtoni, in Korres section (Fig. 13).

- Sistanites iranicus, in Aixola-Ermua section (Fig. 14).

In sum, the new assemblage proposed to characterize SBZ 4 is formed by Glomalveolina levis, Alveolina korresensis, Hottingerina lukasi, Daviesina garumnensis, Assilina yvettae, Assilina azilensis and Nummulites catari.

The study of calcareous nannoplankton (NP and CNP zones) and planktonic foraminifera ( $\mathrm{P}$ zones) allows for a correlation of these zones with the SBZ.

The SBZ 1 biozone can be correlated with calcareous plankton in the Aixola-Ermua and Monte Urko sections.
In Aixola-Ermua it encompasses the interval pertaining to the lower part of P1 zone (P1a+b subzones; Fig. 14), while in Monte Urko section, the SBZ 1 is correlated with the lower-middle part of calcareous nannoplankton NP2 or CNP2-partim CNP3 zones (Fig. 15). These data indicate that the top of the SBZ 1 is located within the upper part of NP2 zone, whereas its base at an indeterminate point within this zone. In the Aixola-Ermua section, SBZ 1 is correlated with the lower part of planktonic foraminifera zone P1 (P1a+P1b in Fig. 14).

The SBZ 2 biozone is correlated with calcareous nannofossils in the Urko section, in the interval comprised between the upper part of NP2 and the upper part of NP 4, or the lower part of CNP3 and the beginning of CNP7 (Fig. 15), and in part with P1c to P3 zones of the planktonic foraminifera in the Aixola-Ermua section (Fig. 14). Biostratigraphic data from the platform margin series studied by Baceta et al. (2005) document a correlation of the SBZ 2 with calcareous nannoplancton biozones spanning from the middle part of NP3 to the uppermost of the NP4. The discrepancy in the position of the base of the SBZ 2 as to that defined at the Monte Urko section most likely derives from the absence of shallow benthic foraminifera in the Da1 DS deposits exposed at Lizarraga pass section.

The SBZ 3 biozone is correlated with the biostratigraphic interval between the lowermost NP 5 and the topmost NP 8 zones (partim CNP7-partim CNP10) of calcareous nannoplankton in the Andia and Aixola-Ermua sections (Figs. 9; 14) and with the P4 planktonic foraminiferal zone in the late section. Finally, SBZ 4 biozone is correlated with partim NP9 or partim CNP11 zones of calcareous nannoplankton in the Campo and Aixola-Ermua sections (Figs. 5; 14).

The Paleocene-Eocene boundary is represented by the geochemical signal of a CIE according to Orue-Etxebarria et al. (2001) and Pujalte et al. (2009b). This excursion is located in the Campo, Urrobi and Aixola-Ermua sections (Figs. 5; 8; 14) according to Schmitz and Pujalte (2003), Pujalte et al. (2003) and Pujalte et al. (2009a, b).

The biostratigraphic range of the species studied in this work is represented in Figure 28, in accordance with the International Chronostratigraphic Chart 2017 (Cohen et al. 2013; Vandenberghe et al. 2012).

\section{CONCLUSIONS}

Detailed taxonomic study of the Paleocene larger foraminifer from the Pyrenean basin has allowed us to identify sixty taxa, including two new species of larger 
foraminifera: Alveolina korresensis n. sp. and Valvulineria bacetai n. sp.

The present study has allowed us to redefine and recalibrate the SBZs of the Paleocene according to new correlation data with calcareous nannoplancton and planktnic foraminifera, as follows (Fig. 29):

- $\quad$ SBZ 1. According to the results of this study, Laffitteina bibensis and Bangiana hanseni can be definitively ruled out as markers for SBZ 1, contrary to the indications in Serra-Kiel et al., (1998). The SBZ 1 has, therefore, no exclusive markers and is now redefined to be characterized by an assemblage composed of Valvulineria patalaensis, Stomatorbina? binkhorsti, Planorbulina? antiqua and Bangiana hanseni. This assemblage encompasses the interval between the $\mathrm{K} / \mathrm{Pg}$ boundary and the upper part of the Danian desposits (Da-2 DS). SBZ 1 is constrained by the chronostratigraphic interval between the $\mathrm{K} / \mathrm{Pg}$ boundary and an intermediate point between the CNP2-CNP3 and the NP2-NP3 boundaries, corresponding to the first appearance of the markers of the SBZ 2.

- $\quad \boldsymbol{S B Z} 2$ is characterized by the assemblage of Haymanella elongata, Haymanella paleocenica, Kayseriella decastroi, Rotospirella conica, Pyrenerotalia depressa Elazigina dienii, Ornatononion moorkensii and Paralockhartia eos. This zone is reasigned in age to the interval from topmost NP2 to uppermost NP4 calcareous nannofossil zones (CNP3 to lowermost CNP7, Fig. 29).

- $\quad \boldsymbol{S B Z} 3$ is characterized by the assemblage of Glomalveolina primaeva, Periloculina slovenica, Vania anatolica, Coskinon rajkae, Fallotella alavensis, Cribrobulimina carniolica, Miscellanea yvettae, Miscellanea juliettae, Miscellanites primitivus, Miscellanites minutus, Ranikothalia soldadensis, "Operculina" heberti and Discocyclina seunesi. This

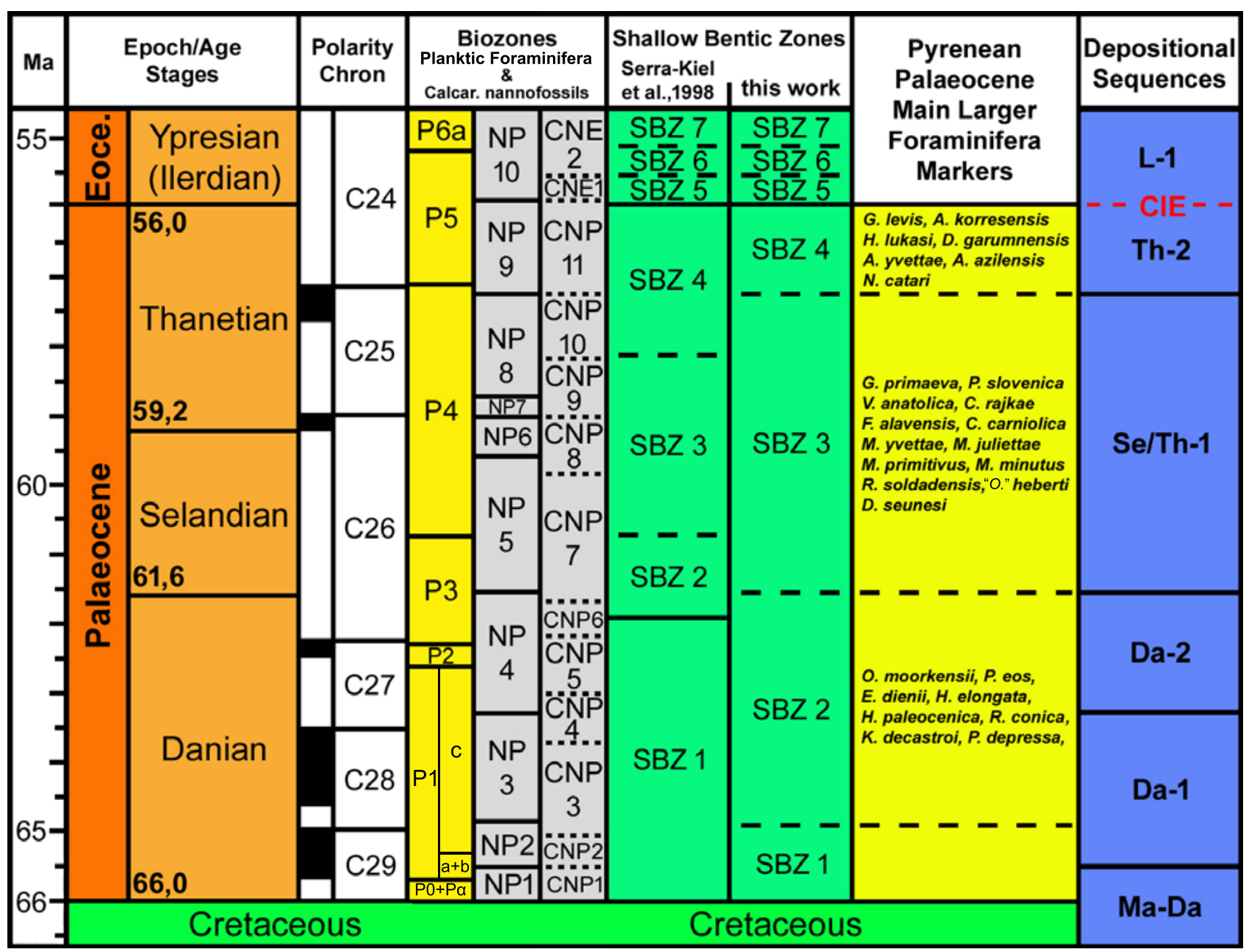

FIGURE 29. Correlation between the Geological Time Scale, magnetostratigraphy, planktic foraminifera zones (P), calcareous nannoplankton zones (NP, CNP), shallow benthic zones (SBZs) according to Serra-Kiel et al. (1998), the SBZs in this work, Paleocene main larger foraminifera markers and the depositional sequences (DS). 
zone encompasses from lower NP5 to topmost NP8 calcareous nannofossil zones (CNP7 to CNP10, Fig. 29).

- $\quad S B Z 4$ is characterized by the assemblage of Glomalveolina levis, Alveolina korresensis, Hottingerina lukasi, Daviesina garumnensis, Assilina yvettae, Assilina azilensis and Nummulites catari. In age this zone encompasses the NP9 calcareous nannofossil zone (most of CNP11, Fig. 29)

The correlation between larger foraminifera and calcareous nannoplankton in Campo, Andia, Lizarraga, Aixola-Ermua and Urko sections has allowed the calibration of the SBZs with the Geologic Time Scale produced in accordance with the 2017 International Chronostratigraphic Chart (Cohen et al., 2013; Vandenberghe et al., 2012) (Fig. 29).

The main modifications of the biostratigraphic range of the Paleocene SBZ with the Serra-Kiel et al. (1998) are as follows (Fig. 29):

- $\quad$ Reduction of the SBZ 1 range from 4.06m.y. to 1.09 m.y.

- $\quad$ Extension of the SBZ 2 range from 1.19 m.y. to 3.34m.y.

- $\quad$ Extension of the SBZ 3 range from 2+

- $\quad$ The SBZ 3 covers from the base of the Selandian to the middle part of the Thanetian. The SBZ 4 is late Thanetian.

Furthermore, the combined study of calcareous nannoplankton and larger foraminifera improve the correlation between the DS as defined by Baceta et al. $(2004,2005,2011)$ and Schmitz et al. (2011), and the Geological Time Scale (Fig. 2). Thus the ages of these depositional sequences is as follows: Ma-Da DS is Maastrichtian-earliest Danian in age; Da-1 DS is early Danian; Da-2 DS is late Danian; Se/Th-1 DS is Selandian/early-middle Thanetian and Th-2 D is late Thanetian in age.

\section{ACKNOWLEDGMENTS}

We acknowledge the financial support for this contribution from the Spanish Ministry of Economy and Competitiveness projects CGL 2015-69805-P and CGL2015-65404-R. This is also a contribution to the Research Group of the Basque University System IT-93016. This study was also conducted in the framework of the research and collections projects of the Museu de Ciències Naturals de Barcelona (MCNB). Sincere thanks to the reviewers Johannes Pignatti and Josep Tosquella for their constructive comments and suggestions.

\section{REFERENCES}

Accordi, G., Carbone, F, Pignatti, J., 1998. Depositional history of a Paleogene carbonate ramp (Western Cephalonia, Ionian Islands, Greece). Geologica Romana, 34, 131-205.

Afzal, J., Williams, M., Aldbridge, R., 2009. Revised stratigraphy of the lower Cenozoic succession of the Grater Indus Basin in Pakistan. Journal of Micropalaeontology, 28, 7-23.

Agnini, A., Fornaciari, E., Raffi, I., Catanzariti, R., Pälike H., Backman, J., Rio, D., 2014. Biozonation and biochronology of Paleogene calcareous nannofossils from low and middle latitudes. Newletter on Stratigraphy, 47/2, 131-181.

Amiot, M., 1982. El Cretácico superior de la región NavarroCántabra. El Cretácico de España. Universidad Complutense de Madrid, 88-111.

Archiac d', E.J.A.D., Haime, J., 1853. Description des animaux fossiles du groupe nummulitique de l'Inde: précédée d'un résumé géologique et d'une monographie des nummulites. Gide et Baudry Paris. part. 1

Baceta, J.I., 1996. El Maestrichtiense Superior, Paleoceno e Ilerdiense Inferior de la región Vasco-Cantabrica: Secuencias Deposicionales, Facies y Evolución Paleogeográfica. Ph. Doctoral Thesis. Euskal Herriko Unibertsitatea, 1-372.

Baceta, J.I., Wright, V.P., Pujalte, V., 2001. Palaeo-mixing zone karst features from Palaeocene carbonates of north Spain: criteria for recognizing a potentially widespread but rarely documented diagenetic system. Sedimentary Geology, 139, 205-216.

Baceta, J.I., Pujalte, V., Serra-Kiel, J., Robador, A., OrueEtxebarria, X., 2004. El Maestrichtiense final, Paleoceno e Ilerdiense inferior de la Cordillera Pirenaica. In: Vera J.A. (ed.). Geología de España. Sociedad Geológica de España, Madrid, Instituto Geológico y Minero de España, 308-313.

Baceta, J.I., Pujalte, V., Bernaola, G., 2005. Paleocene coralgal reefs of the western Pyrenean Basin, N Spain: evidence concerning the post-Cretaceous recovery of reefal ecosystems. Palaeogeography, Palaeoclimatology, Palaeoecology, 224, 117-143.

Baceta, J.I., Bernaola, G., Arostegi, J., 2006a. The mid-Paleocene interval at Zumaia. 4.2 Lithostratigraphy. In: Bernaola, G., Baceta, J.I., Payros, A., Orue-Etxebarria, X., Apellaniz, E. (eds.). The Paleocene and lower Eocene of the Zumaia section (Basque Basin). Climate and Biota of the Early Paleogene 2006. Bilbao, Post Conference Field Trip Guidebook, 38-42.

Baceta, J.I., Pujalte, V., Caballero, F. (eds.), 2006b. Paleocene and Early Eocene facies and events: a basin-platformcoastal plain transect (South-Central and Western Pyrenees). Climate and Biota of the early Paleogene 2006. Bilbao, Post Conference Field Trip Guidebook, 1-94.

Baceta, J.I., Wright, V.P., Beavington-Penney, S.J., Pujalte, V., 2007. Palaeohydrological control of palaeokarst macro-porosity genesis during a major sea-level lowstand: Danian of the Urbasa-Andia plateau, Navarra, North Spain. Sedimentary Geology, 199, 141-169.

Baceta, J.I., Pujalte, V., Wright, P., Schmitz, B., 2011. Carbonate platform models sea-levels changes and extreme climatic 
events during the Paleocene-early greenhouse interval: a basin-platform-coastal plain transect across the southern Pyrenean basin. In: Arenas, C., Pomar, L., Colombo, F (eds.). Pre-Meeting Field Trips Guidebook, 28th IAS Meeting. Zaragoza, Sociedad Geológica de España, Geo-Guías, 7, 151-198.

Bassi, D., 2003. Reassessement of Solenomeris afonensis Maslov, 1956 (Foraminifera): formerly considered a coralline red alga. Revista Española de Micropaleontología, 35(3), 337-343.

Berlanga, J.A., 1997. Macroforaminíferos del Terciario inferior del sureste de México. Doctoral Thesis. Barcelona, Universitat Autònoma de Barcelona, 207pp, 45pls.

Bernaola, G., 2002. Los nannofósiles calcáreos del Paleoceno en el Dominio Pirenaico. Bioestratigrafía, cronoestratigrafía y paleoecología. Doctoral Thesis. Euskal Herriko Unibertsitatea, 445pp.

Bernaola, G., Nuño-Arana, Y., 2006. Calcareous nannofossil assemblages across the mid-Paleocene. In: Bernaola, G., Baceta, J.I., Payros, A., Orue-Etxebarria, X., Apellaniz, E. (eds.). The Paleocene and lower Eocene of the Zumaia section (Basque Basin). Climate and Biota of the Early Paleogene 2006. Bilbao, Post Conference Field Trip Guidebook, 44-46.

Bernaola, G., 2007. New high-resolution calcareous nannofossil analysis across the Danian-Selandian transition at the Zumaya section: Comparison with South Tethys and Danish sections. Zumaia (Basque Country), International Workshop of the Paleocene Working Group, Abstract, 13-17.

Bernaola, G., Baceta, J.I., Orue-Etxebarria, X., Alegret, L., MartínRubio, M., Arostegui, J., Dinarès-Turell, J., 2007. Evidence of an abrupt environmental disruption during the mid-Paleocene biotic event (Zumaia section, western Pyrenees). Geological Society of America Bulletin, 119(7-8), 785-795.

Bernaola, G., Martín-Rubio, M., Baceta, J.I., 2009. New high resolution calcareous nannofossil analysis across the Danian/ Selandian transition at the Zumaia section: comparison with South Tethys and Danish sections. Geologica Acta, 7(1-2), 79-92.

Bignot, G., Larsonneur, C., 1969. Étude du Crétacé Supérieur au large du Cotentin et remarques sur les Planorbulina du Crétacé Supérieur et du Paléocène. Revue de Micropaléontologie, 12(1), 25-39, 3pls.

Bignot, G., 1987. Les paleoenvironnements et les paleogeographies du Bassin de Paris au Danien, d'apres les Foraminifères du Mont Aimé (Marne, France). Revue de Micropaléontologie, 30(3), 150-176.

Bignot, G., 1993. The position of the Montian stage and related fàcies within the Stratigraphic-Paleogeographic framework of NW Europe during the Danian Contributions to Tertiary and Quaternary Geology, 29(3-4), 47-59.

Bignot, G., Quesnel, F, Bourdillon, C., 1997. Le Crétacé terminal et le Paléocène basal de l'Europe nord-occidentale. Géologie de la France, 3, 21-27.

Butterlin, J., Bonet, F., 1960. Microfauna del Eoceno Inferior de la Península de Yucatán. Paleontología Mexicana, México, Instituto de Geologia, 7, 1-18.
Butterlin, J., Monod, O., 1969. Biostratigraphie (Paléocène a Eocène moyen) d'une coupe dans le Taurus de Beysehir (Turquie). Etude des «Nummulites cordelŭes» et révision de ce groupe. Eclogae geologicae Helvetiae, 62(2), 583-604.

Bykova, N.K., 1939. Фораминиферы верхнемеловых и палеогеновых отложений Ферганской долины Foraminifera from the Upper Cretaceous and Paleogene deposits of Ferghana. Тр. НГРИ - Trudy Neftyanogo Geologo-Razvedochnogo Instituta, ser. A, 121, 3-39.

Caudri, C.M.B., 1944. The larger foraminifera from San Juan de los Morros, State of Guarico, Venezuela. Bulletins of American Paleontology, 28(114), 355-404.

Caudri, C.M.B., 1975. Geology and palaeontology of Soldado Rock, Trinidad (West Indies) Part 2: The larger foraminifera. Eclogae Geologicae Helvetiae, Basel, 68(3), 533-589, 30Pls.

Caudri, C.M.B., 1996. The larger foraminifera of Trinidad (West Indies). Eclogae Geologicae Helvetiae, Basel, 89(3), 1137-1309.

Caus, E., Hottinger, L., Tambareau, Y., 1980. Plissements du septal flap et système de canaux chez Daviesina, foraminifères paléocènes. Eclogae geologicae Helvetiae, 73(3), 1045-1069.

Cohen, K.M., Finney, S.C., Gibbard, P.L., Fan, J.-X., 2013. The ICS International Chronostratigraphic Chart. Episodes, 36, 199-204.

Cuevas, J.L., 1992. Estratigrafía del «Garumniense» de la Conca de Tremp. Prepirineo de Lérida. Acta Geológica Hispánica, 27, 95-108.

Cuevas-Gozalo, M., Donselaar, M.E., Nio, S.D., 1985. Eocene clastic tidal deposits in the Tremp-Graus Basin (Provs. of Lérida and Huesca). Lérida, 6th European Regional Meeting, I.A.S., Guidebook Excursion, 6, 215-266.

Cushman, J.A. 1947. Ammobaculites paleocenicus Cushman, a new name. Contributions from the Cushman Laboratory for Foraminiferal Research, 23, 77.

Cushman, J.A., Bermúdez, P.J., 1947. Some Cuban Foraminifera of the genus Rotalia. Contributions from the Cushman laboratory for foraminiferal research, 23(2), 23-29.

Davies, L.M., Pinfold, E.S., 1937. The Eocene beds of the Punjab Salt Range. Memoirs of the Geological survey of India, Palaeontologia Indica, 24, 1-79.

De Castro, P., 1971. Osservazioni sui generi Rhapydionina Stache e Rhipidionina Stache (Foraminiferida). Atti dell'Accademia Pontaniana, 21, 1-4.

Di Carlo, M., Accordi, G., Carbone, F, Pignatti, J., 2010. Biostratigraphic analysis of Paleogene lowstand wedge conglomerates of a tectonically active platform margin (Zakynthos Island, Greece). Journal of Mediterranean Earth Sciences, 2, 31-92.

Douvillé, H., 1922. Révision des Orbitoïdes. Deuxième partie. Orbitoïdes du Danien et l'Éocène. Bulletin de la Société Géologique de France, série 4, 22, 55-100.

Douvillé, H., 1924. Un nouveau genre d'algues calcaires. Comptes Rendus Sommaires de la Société Géologiquede France, 4, 169-170. 
Drobne, K., Hottinger L., 1971. Broeckinella und Saudia (Foraminiferida) aus dem nordwestlichen Teil Jugoslawiens. Ihre Morphologie und ihre stratigraphische Verbreitung. Razprave, (4 razred), Slovenska Akademija Znanosti in Umetnosti, 2(7), 1-26.

Drobne, K., 1974. Les grandes miliolidés des couches paléocènes de la Yougoslavie du Nord-Ouest. Razprave, (4 razred), Slovenska Akademija Znanosti in Umetnosti, 17(3), 1-60.

Drobne, K., 1975. Hottingerina lukasi n. gen., n. sp. (Foraminiferida) du Paléocène Moyen provenant du NordOuest de la Yougoslavie. Razprave, (4 razred), Slovenska Akademija Znanosti in Umetnosti, 18(8), 1-15.

Drobne, K., 1977. Alvŭolines palŭogunes de la Slovénie et de l'Istrie. Mémoires suisses de Paléontologie, 99, 1-132.

Drobne, K., 1984. Periloculina slovenica, B form, from the Paleocene of Majevica Mt. (Yugoslavia) and the new family Fabulariidae. Razprave, (4 razred), Slovenska Akademija Znanosti in Umetnosti, 25(1), 1-32.

Drobne, K., Ogorelec, B., Plenicar, M., Zucchi-Stolfa, M.L., Turnsek, D., 1988. Maastrichtian, Danian and Thanetian beds in Dolenja Vas (NW Dinarides, Yugoslavia). Mikrofacies, Foraminifers, Rudists and Corals. Razprave, (4 razred), Slovenska Akademija Znanosti in Umetnosti, 29, 147-224.

Drobne, K., Ogorelec, B., Riccamboni, R., 2007. Bangiana hanseni n. gen. n. sp. (Foraminifera), and index species of Danian age (Lower Paleocene) from the Adriatic Carbonate Platform (SW Slovenia, NE Italy, Herzegovina). Razprave, (4 razred), Slovenska Akademija Znanosti in Umetnosti, 48, 5-71.

Eichenseer, H., 1988. Facies geology of Late Maastrichtian to Early Eocene coastal and shallow marine sediments, Tremp-Graus basin, northeastern Spain. Arbeiten Institut und Museum für Geologie und Paläontologie, Universität Tübingen, 1, 1-273.

Ferrer, J., Le Calvez, Y., Luterbacher, H.-P., Premoli-Silva, I., 1973. Contribution à l'étude des foraminifères Ilerdiens de la région de Tremp (Catalogne). Mémoires Museum Nationale Histoire Naturelle, Sér. C, 29, 3-107.

Garrido-Megías, A., Ríos, L.M., 1972. Síntesis geológica del Secundario y Terciario entre los ríos Cinca y Segre (Pirineo Central de la vertiente surpirenaica, provincias de Huesca y Lérida). Boletín Geológico y Minero, 83, 1-47.

Grimsdale, Th.F., 1952. Cretaceous and Tertiary Foraminifera from the Middle East. Bulletin British Museum (Nat. History) Geology, 1, 221-248.

Guernet, C., Villier, L., 2017. Les ostracodes de la collection de P. Margerie et l'âge des couches à Laffittéines du Mont Aimé (bassin de Paris, France). Geodiversitas, 39(2), 225-249. DOI: $10.5252 / \mathrm{g} 2017 \mathrm{n} 2 \mathrm{a} 4$

Haque, A., 1956. The smaller foraminifera of the Ranikot and the Laki of the Nammal Gorge, Salt Range. Paleontologica Pakistanica. Memories Geological Survey of Pakistan, 1, 1-228.

Hasson, P.F, 1985. New observations on the biostratigraphy of the Saudi Arabian Umm er Radhuma Formation (Paleogene) and its correlation with neighbouring regions. Micropaleontology, 31(4), 335-364.
Hofker, J., 1966, Maestrichtian, Danian and Paleocene foraminifera. The foraminifera of the type-Maestrichtian in south Limburg, Netherlands, together with the foraminifera of the underlying Gulpen Chalk and the overlying calcareous sediments; the foraminifera of the Danske Kalk and the overlying greensands and clays as found in Denmark. Palaeontographica, 1-375.

Hottinger, L., 1960. Recherches sur les Alvéolines du Paléocène et de l'Eocène. Mémoires suisses de Paléontologie, 75, 1-243, $76,1-18$.

Hottinger, L., 1964. Les genres Operculina et Heterostegina (Foraminifères) et leur utilité stratigraphique. Mémoires Bureau Recherches Géologiques et Minières, 28(2), 1014-1031.

Hottinger, L., 1974. Alveolinids, Cretaceous-Tertiary Larger Foraminifera. Esso Production Research-European Laboratories, 1-84.

Hottinger, L., 1977. Foraminifères operculiniformes. Mémoires Museum National Histoire Naturelle, Sèr. C40, 159pp.

Hottinger, L., Drobne, K., 1980. Early Tertiary conical imperforate foraminifera. Razprave, (4 razred), Slovenska Akademija Znanosti in Umetnosti, 22(3), 90pp.

Hottinger, L., 2006. The "face" of benthic foraminifera. Bolletino della Società Paleontologica Italiana, 45, 75-89.

Hottinger, L., 2009. The Paleocene and earliest Eocene foraminiferal Family Miscellaneidae: neither nummulitids nor rotaliids. Brest, Notebooks on Geology, CG 2009-A06, $1-41$.

Hottinger, L., 2014. Paleogene larger rotaliid foraminifera from the western and central Neotethys. Heidelberg, New York, Dordrecht, London, Springer Cham, 1-196.

Inan, N., 1988. Sur la présence de la nouvelle espèce Cuvillierina sireli dans le Thanetien de la Montagne de Tercer (Anatolie Centrale, Turquie). Revue de Paléobiologie, 7(1), 121-127.

Kuss, J., Leppig, U., 1989. The early Tertiary (middle-late Paleocene) limestones from the western Gulf of Suez, Egypt. Abh. Neues Jahrbuch für Geologie und Paläontologie, 177(3), 289-332.

Leppig, U., 1988a. Structural analysis and taxonomic revision of Miscellanea, Paleocene larger Foraminifera. Eclogae geologicae Helvetiae, 81(3), 689-721.

Leppig, U., 1988b. Miscellanea, structure and stratigraphic distribution. Revue de Paléobiologie, 2 (vol. spéc. Benthos'86, Genève), 691-694.

Less, G., 1987. Paleontology and stratigraphy of the European Orthophragminae. Geologica Hungarica, Series Palaeontologica, Fasc. 3, 1-282.

Leymerie, A., 1868. Récit d'une exploration géologique de la vallée du Segre. Bulletin Société Géologique France, 23, 550-551.

Loeblich, A.R., Tappan, H., 1964. Treatise on Invertebrate Paleontology, Part C: Protista 2, Sarcodina, chiefly "Thecamoebians" and Foraminiferida. Lawrence, Geological Society of America and University of Kansas Press, 900pp.

Loeblich, A.R.Jr., Tappan, H., 1987. Foraminiferal Genera and their Classification. Van Nostrand Reinhold, 970pp. 
López-Martínez, N., Peláez-Campomanes, P., 1999. New mammals from South-central Pyrenees (Tremp Formation, Spain) and their bearing on Late Paleocene marinecontinental correlations. Bulletin de la Société Géologique de France, 170, 681-686.

López-Martínez, N., Arribas, M.E., Robador, A., Vicens, E., Ardèvol, Ll., 2006. Los carbonatos Danienses (Unidad 3) de la Fm. Tremp (Pirineos Sur-Centrales): Paleogeografía y Relación con el límite Cretácico-Terciario. Revista de la Sociedad Geológica de España, 19(3-4), 233-255.

Mangin, J.Ph., 1954. Description d'un nouveau genre de foraminifère Fallotella alavensis. Bulletin Sciences Bourgogne, 14, 209-219.

Mangin, J.Ph., 1955. Etude sur "Operculina" heberti MunierChalmas, 1882. Bulletin Sciences Bourgogne, 15, 241-251.

Mangin, J.Ph., 1960. Le Nummulitique sud-pyrénéen à l'Ouest de l'Aragon. Pirineos, 51-58, 631pp.

Mangin, J.Ph., 1966. Les courbes de croissance chez les Operculines: notion d'espèce en paléontologie et méthode rapide de détermination. Eclogae geologicae Helvetiae, 59(1), 347-353.

Marie, P., 1946. Sur Laffitteina bibensis et Laffitteina monodi nouveau genre et nouvelles espéces du Foraminifères du Montien. Bulletin de la Société géologique de France, 5(15) (1945), 419-434.

Marsson, Th., 1878, Die Foraminiferen der Weissen Schreibkreide der Inseln Rügen, Mitteilungen des Naturwissenchaftlichen Vereins für Neu-Vorpommern und Rügen in Greifswald, 10, 115-196.

Martini, E., 1971. Standard Tertiary and Quaternary calcareous nannoplankton zonation. In: Farinacci, A. (ed.) Proceedings of the 2nd Planktonic Conference. Roma, Tecnoscienza, 739-785.

Mathey, B., 1982. El Cretácico superior del Arco Vasco. In: El Cretácico de España. Universidad Complutense de Madrid, 111-135.

Mey, P.W.H., Nagtegaal, P.J.C. Roberti, K.J., Hartevelt, J.J.A., 1968. Lithostratigraphic subdivision of posthercynian deposits in the south-central Pyrenees, Spain. Leidse Geologische Mededelingen, 41, 221-228.

Munier-Chalmas, E., 1884. Observations sur le dimorphisme des Nummulites. Bulletin de la Société géologique de France (sèrie 3), 10, 424-427.

Neumann, M., 1972. Sur les Orbitoididés du Crétacé supérieur et du Tertiaire. Revue de Micropaléontologie, 15(3), 163-189.

Ogorelec, B., Drobne, K., Jurkovsek, T., Toman, M., 2001. Paleocene beds of the Liburnian Formation in Cebulovica (Slovenia, NW Adriatic Dinaric platform). Ljubljana, Geologija, 44(1), 15-65.

Orue-Etxebarria, X., Apellaniz, E., Baceta, J.I., Coccioni, R., di Leo, R., Dinarés-Turell, J., Galeotti, S., Monechi, S., NúñezBetelu, K., Parés ,J.M., Payros, A., Pujalte, V., Samsó, J.M., Serra-Kiel, J., Schmitz, B., Tosquella, J., 1996. Physical and biostratigraphy analysis of two prospective Paleocene-Eocene Boundary Stratotypes in the intermediate-deep water Basque
Basin, western Pyrenees: The Trabakua Pass and Ermua sections. Neues Jahrbuch für Geologie und Paläontologie, 201(2), 179-242.

Orue-Etxebarria, X., Pujalte, V., Bernaola, G., Apellaniz, E., Baceta, J.I., Payros, A., Nuñez-Betelu, K., Serra-Kiel, J., Tosquella, J., 2001. Did the Late Paleocene thermal maximum affect the evolution of larger foraminifers? Evidence from calcareous plankton of the Campo section (Pyrenees, Spain). Marine Micropaleontology, 41, 45-71.

Orbigny, A.D.d',, 1850-1852. Prodrome de paléontologie stratigraphique universelle des animaux mollusques et rayonnés faisant suite au cours élémentaire de paléontologie et de géologie stratigraphiques. Paris, Masson, vol. 1 [January 1850 (“1849”)]: 1x + 394pp.; vol. 2 [November 1850]: 427pp.; vol. 3 [1852]: 389pp.

Özgen, N., Akyazi, M., 2001. Padriciano (Italya), Sopada (Slovenia) ve Bati Pontid (Türkiye) Tanesiyen'inin bentik foraminifer toplulugu. Yerbilimieri, 23, 87-98.

Perch-Nielsen, K., 1981. Les nannofossiles calcaires à la limite Crétacé-Tertiaire près de El Kef, Tunisie. Cahiers de Micropaléontologie, 3, 25-37.

Perch-Nielsen, K., 1985. Cenozoic calcareous nannofossils. In: Bolli, H.M., Saunders, J.B., Perch-Nielsen, K. (eds.). Plankton Stratigraphy. Cambridge, Cambridge University Press, 427-554.

Perrin, C., 1987. Solenomeris: un Foraminifère Acervulinidae constructeur de récifs. Revue de Micropaléontologie, 30, 197-206.

Perrin, C., 1994. Morphology of encrusting and free living acervulinid Foraminifera: Acervulina, Gypsina and Solenomeris. Palaeontology, 37(2), 425-458.

Peybernès, B., Fondecave-Wallez, M.-J., Hottinger, L., Eichène, P., Segonzac, G., 2000. Limite Crétacé-tertiaire et biozonation micropaléontologique du Danien-Sélandien dans le Béarn occidental et la Haute-Soule (Pyrénées Atlantiques). Geobios, $33,35-48$.

Pfender, J., 1938. Les foraminifères du Valanginien provençal, Bulletin de la Société Géologique de France, ser. 58, 231-242.

Pignatti, J., Matteucci, R., Parlow, T., Fantozzi, L., 1998. Larger foraminiferal biostratigraphy of the Maastrichtian-Ypresian Wadi Mashib succession (South Hadramawt Arch, SE Yemen). Zeitschrift fur geologische Wissenschaften, Berlin, 26(5-6), 609-635.

Pignatti, J., Di Carlo, M., Benedetti, A., Bottino, C., Briuglio, A., Falconi, M., Matteucci, R., Perugini, G., Ragusa, M., 2008. SBZ 2-6 Larger Foraminiferal Assemblages from the Apulian and Pre-Apulian Domains. Atti del Museo Civico di Storia Naturale di Trieste, 53 (supplement), 131-146.

Plummer, H.J., 1927. Foraminifera of the Midway formation in Texas. University of Texas Bulletin, 2644, 1-206.

Pujalte, V., Robles, S., Robador, A., Baceta, J.I., Orue-Etxebarria, X., 1993. Shelf-to-Basin Palaeocene Palaeogeography and Depositional Sequences, Western Pyrenees, North Spain. In: Posamentier, H.W., Summerhayes, C.P., Haq, B.U., Allen, G.P. (eds.). Sequence Stratigraphy and Facies Associations. 
International Association of Sedimentologists, 18 (Special Publication), 369-395.

Pujalte, V., Baceta, J.I., Payros, A., Orue-Etxebarria, X., Serra-Kiel, J., 1994. Late Cretaceous- September 1994, Middle Eocene Sequence Stratigraphy and Biostratigraphy of the SW. and W. Pyrenees. A Field-Seminar of the Groupe de Etude du Paleogene and IGCP Project 286, 1-118.

Pujalte, V., Schmitz, B., Baceta, J.I, Orue-Etxebarria, X., NuñezBetelu, K., Payros, A., Serra-Kiel, J., 1998a. Paleocene of the Pyrenees and the North Sea Basin: differences and similarities. Newsletter on Stratigraphy, 36, 43-47.

Pujalte, V., Baceta, J.I, Apellaniz, E., Orue-Etxebarria, X., Payros, A., Serra-Kiel, J., 1998b. An Early Ilerdian transient switchoff in shallow and deep-water carbonate deposition in the western Pyrenees, Spain. Strata, 9, 111-112.

Pujalte, V., Robles, S., Orue-Etxebarria, X., Baceta, J.I., Payros, A., Larruzea, I.F, 2000a. Uppersmost Cretaceous-middle Eocene strata of the Basque-Cantabrian Region and western Pyrenees: a sequence stratigraphic perspective. Revista de la Sociedad Geológica de España, 3(2), 191-211.

Pujalte, V., Baceta, J.I., Payros, A., Orue-Etxebarria, X., Schmitz, B., 2000b. Upper Paleocene-lower Eocene strata of the western Pyrenees, Spain: a shelf-to-basin correlation. The Geological Society of Sweden (Geologiska Föreningen), 122(1), 129-130.

Pujalte, V., Baceta, J.I., Payros, A., 2002. Tertiary of the western Pyrenees and Basque-Cantabrian region. In: Gibbons, W., Moreno, M.T. (eds.). The Geology of Spain. Geological Society of London, 293-301.

Pujalte, V., Orue-Etxebarria, X., Schmitz, B., Tosquella, J., Baceta, J.I., Payros, A., Caballera, F, Apellaniz, E., 2003. Basal Ilerdian (earliest Eocene) turnover of larger foraminifera: Age constraints based on calcareous plankton and $\delta^{13} \mathrm{C}$ isotopic profiles from new southern Pyrenean sections (Spain). In: Wing, S.L., Gingerich, P.D. Schmit, B., Thomas, E. (eds.). Causes and Consequences of Globally Warm Climates in the Early Paleogene, Boulder, Colorado. Geological Society of America, 369 (Special Paper), 205-221.

Pujalte, V., Schmitz, B., Baceta, J.I., Orue-Etxebarria, X., Bernaola, G., Dinarès-Turell, J., Payros, A., Apellaniz, E., Caballero, F, 2009a. Correlation of the Thanetian-Ilerdian turnover of larger foraminifera and the Paleocene-Eocene thermal maximum: confirming evidence from the Campo area (Pyrenees, Spain). Geologica Acta, 7(1-2), 161-175.

Pujalte, V., Baceta, J.I., Schmitz, B., Orue-Etxebarria, X., Payros, A., Bernaola, G., Apellaniz, E., Caballero, F., Robador, A., Serra-Kiel, J., Tosquella, J., 2009b. Redefinition of the Ilerdian Stage (early Eocene). Geologica Acta, 7(1-2), 177-194. DOI: 10.1344/105.000000268

Pujalte, V., Robador, A., Payros, A., Samsó, J.M., 2011. Sea level changes across the PETM in the Pyrenees, part 2: evidence from a platform interior setting. In: Egger, H. (ed.). Climate and Biota of the Early Paleogene, Conference Program and Abstracts, Salzburg, Austria. Berichte der Geologischen Bundesanstalt, 85, 132.
Pujalte, V., Schmitz, B., Baceta, J.I., 2014. Sea-level changes across the Paleocene-Eocene interval in the Spanish Pyrenees, and their possible relationship with North Atlantic magmatism. Palaeogeography, Palaeoclimatology, Palaeoecology, 393, 45-60.

Pujalte, V., Robador, A., Payros, A., Samsó, J.M., 2016. A siliciclastic braid delta within a lower Paleogene carbonate platform (Ordesa-Monte Perdido National Park, southern Pyrenees, Spain: Record of the Paleocene-Eocene Thermal Maximum perturbation. Palaeogeography, Palaeoclimatology, Palaeoecology, 459, 453-470.

Rahaghi, A., 1978. Paleogene biostratigraphy of some parts of Iran. National Iranian Oil Company, Geological Laboratories, Teheran, 7, 82pp.

Rahaghi, A., 1983. Stratigraphy and faunal assemblage of Paleocene-Lower Eocene in Iran. National Iranian Oil Company, Geological laboratories, Teheran, 10, 1-73, 49pp.

Reichel, M., 1937. Étude sur les Alvéolines. Mémoires Société Paléontologie Suisse, 57(59), 1-147.

Reuss, A.E., 1846. Die Versteinerungen der böhmischen Kreideformation. Stuttgart, E. Schweizerbart'sche Verlagsbuchhandlung und Drückerei, 1, 1-58.

Reuss, A.E., 1862. Paläontologische Beiträge. Sitzungsberichte der Kaiserlichen Akademie der Wissenschaften. Mathematisch-Naturwissenschaftliche Classe. Abt. 1, Mineralogie, Botanik, Zoologie, Anatomie, Geologie und Paläontologie, 44, 301-342.

Robador, A., 1991. Early Paleogene Stratigraphy. In: ITGE (ed.). Introduction to the Early Paleogene of the South Pyrenean Basin Field trip guidebook. First Meeting I.G.C.P. Project 286 (Early Paleogene Benthos), IUGS-UNESCO, 42-87.

Robador, A., Orue-Etxebarria, X., Serra-Kiel, J., 1991a. The Correlation between biozonation of benthonic and planktonic foraminifera. In: ITGE (ed.). Introduction to the Early Paleogene of the South Pyrenean Basin Field trip guidebook. First Meeting I.G.C.P. Project 286 (Early Paleogene Benthos), IUGS-UNESCO, 97-100.

Robador, A., Samsó, J.M., Serra-Kiel, J., Tosquella, J., 1991b. Field Guide. In: ITGE (ed.). Introduction to the early Paleogene of the south Pyrenean basin. Field trip guidebook, First Meeting I.G.C.P. Project 286 (Early Paleogene Benthos), IUGSUNESCO, 132-159.

Robador, A., 2005. El Paleoceno e Ilerdiense inferior del Pirineo occidental: Estratigrafía y sedimentología. Doctoral Thesis. Bilbao University, 312pp, Annex 144pp.

Robador, A., 2008. El Paleoceno e Ilerdiense inferior del Pirineo occidental: Estratigrafía y Sedimentología. Publicaciones del Instituto Geológico y Minero de España, Madrid, Serie Tesis Doctorales, 12, 312pp.

Rosell, J., Linares, R., Llompart, C., 2001. El «Garumniense» prepirenaico. Revista de la Sociedad Geológica de España, 14, 47-56.

Samuel, O., Borza, K., Köhler, E., 1972. Microfauna and Lithostratigraphy of the Paleogene. Bratislava, Geologický ústav Dionýza Stura, 246pp. 
Samuel, O., Köhler, E., Borza, K., 1977. Haddonia praeheissigi and Miliola? andrusovi, two new species from Upper-Senonian and Paleocene bioherm limestones of West Carpathians (Slovakia). Západné Karpaty, serie paleontology, 2/3, 87-96.

Schaub, H., 1981. Nummulites et Assilines de la Tethys paléogène. Taxinomie, phylogénese et biostratigraphie. Mémoires suisses de Paléontologie, 104-106, 256pp.

Schlumberger, C., Munier-Chalmas, E., 1884. Note sur Ies Miliolidées trématophorées. Bulletin de la Société Géologique de France, sér. 3., 12, 629-630.

Schmitz, B., Pujalte, V., 2003. Sea-level, humidity, and land-erosion records across the initial Eocene thermal maximum from a continental-marine transect in northern Spain. Geology, 31, 689-692.

Schmitz, B., Pujalte, V., Molina, E., Monechi, S., Orue-Etxebarria, X., Speijer, R.P., Alegret, L., Apellaniz, E., Arenillas, I., Aubry, M.P., Baceta, J.I., Berggren, W.A., Bernaola, G., Caballero, F, Clemmensen, A., Dinarès-Turell, J., Dupuis, C., HeilmanClausen, C., Hilario, Orus, A., Knox, R., Martin-Rubio, M., Ortiz, S., Payros, A., Petrizzo, M.R., Von Salis, K., Sprong, J., Steurbaut, E., Thomsen, E., 2011. The Global Stratotype Section and Points for the bases of the Selandian (Middle Paleocene) and Thanetian (Upper Paleocene) stages at Zumaia, Spain. Episodes, 34(4), 220-243.

Serra-Kiel, J., Robador, A., Samsó, J.M., Tosquella J., 1991. Biostratigraphic aspects to the Early Cenozoic SouthPyrenean Basin. In: ITGE (ed.). Introduction to the Early Paleogene of the South Pyrenean Basin Field trip guidebook. First Meeting I.G.C.P. Project 286 (Early Paleogene Benthos), IUGS-UNESCO, 89-96.

Serra-Kiel, J., Canudo, J.I., Dinares, J., Molina, E., Ortiz, N., Pascual, J.O., Samsó J.M., Tosquella, J., 1994. Cronoestratigrafía de los sedimentos marinos del Terciario inferior de la Cuenca de Graus-Tremp (Zona Central Surpirenaica). Revista de la Sociedad Geológica de España, 7(3-4), 273-297.

Serra-Kiel, J., Hottinger, L., Caus, E., Drobne, K., Ferràndez, C., Jauhri, A.K., Less, G., Pavlovec, R., Pignatti, J., Samsó, J.M., Schaub, H., Sirel, E., Strougo, A., Tambareau, Y., Tosquella, J., Zakrevskaya, E., 1998. Larger foraminiferal biostratigraphy of the Tethyan Paleocene and Eocene. Bulletin de la Société Géologique de France, 169(2), 281-299.

Sirel, E., 1972. Systematic study of new species of the genera Fabularia and Kathina from Paleocene. Bulletin of the Geological Society of Turkey, 73, 145-147.

Sirel, E., Gündüz, H., 1985. Vania, a new foraminiferal genus from the Thanetian of the Van region (East Turkey). Bulletin of the Mineral Research and Exploration Institute of Turkey, 101/102, 20-24.

Sirel, E., 1998. Foraminiferal description and biostratigraphy of the Paleocene-Lower Eocene shallow-water limestone and discussion on the Cretaceous-Tertiary boundary in Turkey. Mineral Research and Exploration (MTA), General Directorate, Ankara, Monography Series 2, 1-117, 68pls.

Sirel, E., 1999. Four new genera (Haymanella, Kayseriella, Elazigella and Orduella) and one new species of Hottingerina from the Paleocene of Turkey. Micropaleontology, 45(2), 113-137.

Sirel, E., 2004. Türkiye'nin Mesozoyik ve Senozoyik Yeni Bentik Foraminiferieri. TMMOB Jeoloji Mühendisleri Odasi Yayinlari, Emegin Bilimsel Sentezi, 1, 84, 1-219, 66pls.

Sirel, E., Acar, S., 2008. Description and Biostratigraphy of the Thanetian-Bartonian Glomalveolinids and Alveolinids of Turkey. Scientific Synthesis of the Lifelong Achievement, TMMOB, UCTEA, 2 (Special Volume), 1-108, 78pls.

Sirel, E., 2009. Reference sections and key localities of the Paleocene Stages and their very shallow/shallow water three new benthic foraminifera in Turkey. Revue de Paléobiologie, 28(2), 413-435.

Sirel, E., 2012. Seven new larger benthic foraminiferal genera from the Paleocene of Turkey. Revue de Paleobiologie, 31(2), 267-301.

Sirel, E., 2013. Description of two new families, three new species and redescription of four know genera and one subfamily from the larger benthic foraminifera of Paleocene in Turkey. Bulletin of the Mineral Research and exploration, 146, 27-53.

Sirel, E., 2015. Reference Sections and Key Localities of the Paleogene Stage and Discussion C-T, P-E and E-O Boundaries by the Very Shallow-Shallow Water Foraminifera in Turkey. Ankara University, Faculty of Engineering, Department of Geological Engineering, 1-64.

Sirel, E., 2018. Revision of the Paleocene and partly early Eocene larger benthic foraminifera of Turkey. Ankara University, Faculty of Engineering, Department of Geological Engineering, 197pp.

Smout, A.H., 1954. Lower Tertiary foraminifera of the Qatar peninsula. British Museum (Natural History), 11-96.

Souquet, P., 1967. Le Crétacé supérieur sudpyrénéen en Catalogne, Aragon et Navarre. Thèse d'Etat. Université de Toulouse, $1-529$.

Tambareau, Y., 1966. Sur une nouvelle espèce d'Operculine cordelée, Operculina (Nummulitoides) azilensis nov. sp. Bulletin Société Histoire Naturelle Toulouse, 102(1), 301-307.

Tambareau, Y., Villatte, J., 1968. Les zones de grands Foraminifères du Paléocène (Thanétien-Sparnacien) de l'avant-pays pyrénéen a l'Est du Plateau de Lannemezan et leur extension. Mémoires Bureau de Recherches Géologiques et Minières, 58, 57-62.

Tambareau, Y., 1972. Thanétien supérieur et Ilerdien inférieur des Petites Pyrénées, du Plantaurel et des Chaînons audois. Travaux du Laboratoire Géologie-Pétrologie de l'Université Paul Sabatier, 383pp.

Tambareau, Y., Villatte, J., 1974. Le passage Thanétien-Ilerdien dans la région de Campo: Comparaison avec les Petites Pyrénées. Bulletin Société Histoire Naturelle Toulouse, 110, 340-361.

Tambareau, Y., Russell, D.E., Sigogneau-Russell, D., Villatte, J., 1992a. Découverte des restes de Vertebrés dans le Paléocène de Campo (Pyrénées aragonaises). Bulletin Société Histoire Naturelle Toulouse, 128, 73-76.

Tambareau, Y., Crochet, B., Déramond, J., Caus, E., Villatte, J., Bessière, Guerrero, N., Eichène, P., 1992b. Stratigraphie, 
J. Serra-Kiel et al.

Paléoenvironnements et Tectonique des Plateformes Paléogènes Nord et Sud Pyrénéennes. Laboratoire de Géologie Structurale et Tectonophysique, 1-86.

Tambareau, Y., Canudo, J., Gruas-Cavagnetto, C., Hottinger, H., Molina, E., 1994a. Excursion to Béarn: Narp, Nouts-Oraas, Gave d'Oloron Valley. In: Introduction to the Early Paleogene of the North Pyrenean Basin Field trip guidebook, Meeting in Aspet I.G.C.P. Project 286 (Early Paleogene Benthos), IUGSUNESCO, 33-39.

Tambareau, Y., Crochet, B., Villatte, V., Déramond, J., 1994b. Eastern End of the Petites Pyrénées and Plantaurel. In: Introduction to the Early Paleogene of the North Pyrenean Basin Field trip guidebook, Meeting in Aspet I.G.C.P. Project 286 (Early Paleogene Benthos), IUGS-UNESCO, 15-32.

Tambareau, Y., Villatte, J., Crochet, B., 1994c. Paleogene of the Northern Central and Eastern Pyrenees. In: Introduction to the Early Paleogene of the North Pyrenean Basin Field trip guidebook, Meeting in Aspet I.G.C.P. Project 286 (Early Paleogene Benthos), IUGS-UNESCO, 7-14.

Tosquella, J., 1995. Els Nummulitinae del Paleocè-Eocè Inferior de la conca Sudpirenenca. Doctoral Thesis. Barcelona, Barcelona University, 581pp.

Tosquella, J., Serra-Kiel, J., 1998a. Nummulites catari: a new species from the Late Palaeocene of the Pyrenean basin. Slovenska akademija znanosti in umetnosti, 34(2), 165-171.

Tosquella, J., Serra-Kiel, J., 1998b. Los nummulítidos (Nummulites y Assilina) del Paleoceno Superior-Eoceno Inferior de la Cuenca Pirenaica: Sistemática. Acta Geologica Hispanica, 31(1-3), 37-159.

Vandenberghe, N., Hilgen, FJ., Speijer, R.P., 2012. The Paleogene Period. In: Gradstein FM., Ogg, J.G., Schmitz, M., Ogg, G. (eds.). The Geologic Time Scale. Elsevier, 856-921.
Paleocene LBF from the Pyrenean Basin

Vaughan, T.W., Cole, W.S., 1941. Preliminary report on the Cretaceous and Tertiary larger foraminifera of Trinidad British West Indies. Boulder, Special Papers of the Geological Society of America, 30, 135pp.

Vaughan, T.W., 1945. American old and middle Tertiary larger foraminifera and corals. Part 1. American Paleocene and Eocene larger foraminifera. Boulder, Geological Society of America Memoirs, 9, 1-167.

Van de Velde, E., 1967. Geology of the Ordesa overthrust mass, Spanish Pyrenees, province of Huesca. Estudios Geología, 26, 163-201.

Vicedo, V., Berlanga, J.A., Serra-Kiel, J., 2014. Paleocene larger foraminifera from the Yucatán Península (SE México). Notebooks on Geology, 14(4), 41-68.

Vicedo, V., Robles-Salcedo, R., Serra-Kiel, J., Hidalgo, C., Razin, Ph., Grélaud, C., 2019. Biostratigraphy and evolution of the larger rotaliid foraminifera in the Cretaceous-Paleogene transition of the southern Oman Mountains. Papers in Paleontology, 1-43.

Villatte, J., 1962. Etude stratigraphique et paléontologique du Montien des Petites Pyrénées et du Plantaurel. Toulouse, Edouard Privat Maitre-Imprimeur, 1-331.

Villatte, J., 1969. Découverte d'une espèce du genre Nummulitoides Abrard 1955 dans la zone a "Operculina" heberti-Discocyclina seunesi du Thanétien des PetitesPyrénées. Compte Rendu Sommaire Séances Société géoligique de France, 9(1968), 299-300.

Wan, X., 1991. Paleocene larger foraminifera from Southern Tibet. Revista Española de Micropaleontología, 23, 7-28.

Wright, V.P., Burchette, T.P., 1996. Shallow-water carbonate environments. In: Reading, H.G. (ed.). Sedimentary environments. 3rd Edition Blackwell Scientific, 325-394.

Manuscript received June 2019;

revision accepted April 2020;

published Online June 2020. 


\section{APPENDIX I}

TABLE I. Morphometrically parameters measured in the equatorial sections of megalospheric forms of the species Nummulites catari Tosquella and Serra-Kiel, 1998

\begin{tabular}{lrrr}
\hline Whorl $\left(\mathrm{n}^{\circ}\right)$ & 1 & 2 & 3 \\
\hline Radius $(\mathrm{mm})$ & $0.41-0.53$ & $0.56-1.11$ & $0.81-1.52$ \\
Septa $\left(\mathrm{n}^{\circ}\right)$ & ago-16 & $37-48$ & $79-103$ \\
\hline
\end{tabular}

TABLE II. Morphometrically parameters measured in the equatorial sections of megalospheric forms of the species Assilina yvettae (SCHAUB, 1981)

\begin{tabular}{lrrr}
\hline Whorl $\left(\mathrm{n}^{\circ}\right)$ & 1 & 2 & 3 \\
\hline Radius $(\mathrm{mm})$ & 0.38 & 0.75 & 1.20 \\
Septa $\left(\mathrm{n}^{\circ}\right)$ & 10 & 29 & 53 \\
\hline
\end{tabular}

TABLE III. Morphometrically parameters measured in the equatorial sections of megalospheric forms of the species Assilina azilensis (TAMBAREAU, 1966)

\begin{tabular}{|c|c|c|c|c|c|}
\hline \multicolumn{6}{|c|}{ Microspheric generation } \\
\hline Whorl $\left(n^{\circ}\right)$ & 1 & 2 & 3 & 4 & 5 \\
\hline Radius (mm) & 0.1 & 0.3 & 0.67 & 1.45 & 2.94 \\
\hline Septa $\left(n^{\circ}\right)$ & 8 & 24 & 44 & 85 & 155 \\
\hline \multicolumn{6}{|c|}{ Megalospheric generation } \\
\hline Whorl $\left(n^{\circ}\right)$ & 1 & 2 & 3 & - & - \\
\hline Radius (mm) & $0.54-0.61$ & $1.08-1.23$ & $1.77-1.99$ & - & - \\
\hline Septa $\left(n^{\circ}\right)$ & 07-nov & $23-32$ & $48-59$ & - & - \\
\hline
\end{tabular}

TABLE IV. Morphometrically parameters measured in the equatorial sections of megalospheric forms of the species Ranikothalia soldadensis (vAUGHAN AND COLE, 1941)

\begin{tabular}{|c|c|c|c|c|}
\hline \multicolumn{5}{|c|}{ Microspheric generation } \\
\hline Whorl $\left(n^{\circ}\right)$ & 1 & 2 & 3 & 4 \\
\hline Radius (mm) & 0.47 & 1.16 & 2.99 & 3.34 \\
\hline Septa $\left(n^{\circ}\right)$ & 11 & 29 & 52 & 87 \\
\hline \multicolumn{5}{|c|}{ Megalospheric generation } \\
\hline Whorl $\left(n^{\circ}\right)$ & 1 & 2 & 3 & - \\
\hline Radius (mm) & $0.50-0.52$ & $1.14-1.19$ & $1.6-1.76$ & - \\
\hline Septa $\left(n^{\circ}\right)$ & 04-may & 20 & $46-49$ & - \\
\hline
\end{tabular}


TABLE V. Samples.

\begin{tabular}{|c|c|}
\hline Sample & Repository \\
\hline Abau 1 & Instituto Geológico y Minero de España (IGME) \\
\hline Ain 30 & Serra-Kiel collection.Department of Earth and Ocean Dynamics, University of Barcelona (UB) \\
\hline Ain 5 & Instituto Geológico y Minero de España (IGME) \\
\hline Aix 12 & Serra-Kiel collection. Department of Earth and Ocean Dynamics, University of Barcelona (UB) \\
\hline Aix 14 & Serra-Kiel collection. Department of Earth and Ocean Dynamics, University of Barcelona (UB) \\
\hline Aix 16 & Department of Stratigraphy and Paleontology, University of the Basque Country (UPV/EHU) \\
\hline Aix 19 & Serra-Kiel collection. Department of Earth and Ocean Dynamics, University of Barcelona (UB) \\
\hline Aix 5 & Serra-Kiel collection. Department of Earth and Ocean Dynamics, University of Barcelona (UB) \\
\hline Aix 9 & Department of Stratigraphy and Paleontology, University of the Basque Country (UPV/EHU) \\
\hline An 1 & Instituto Geológico y Minero de España (IGME) \\
\hline An 10 & Department of Stratigraphy and Paleontology, University of the Basque Country (UPV/EHU) \\
\hline An 8 & Department of Stratigraphy and Paleontology, University of the Basque Country (UPV/EHU) \\
\hline An 9 & Department of Stratigraphy and Paleontology, University of the Basque Country (UPV/EHU) \\
\hline Beo 2 & Instituto Geológico y Minero de España (IGME) \\
\hline Beo 4 & Instituto Geológico y Minero de España (IGME) \\
\hline Beo 5 & Instituto Geológico y Minero de España (IGME) \\
\hline Bin 3 & Instituto Geológico y Minero de España (IGME) \\
\hline Bouzin & Serra-Kiel collection. Department of Earth and Ocean Dynamics, University of Barcelona (UB) \\
\hline Bur 3 & Instituto Geológico y Minero de España (IGME) \\
\hline Bur 7 & Serra-Kiel collection. Department of Earth and Ocean Dynamics, University of Barcelona (UB) \\
\hline Campeche (Mexico) & Serra-Kiel collection. Department of Earth and Ocean Dynamics, University of Barcelona (UB) \\
\hline Cérisols (Petites Pyrénées) & Serra-Kiel collection. Department of Earth and Ocean Dynamics, University of Barcelona (UB) \\
\hline $\mathrm{Cm} 2$ & Serra-Kiel collection. Department of Earth and Ocean Dynamics, University of Barcelona (UB) \\
\hline $\mathrm{Cm} 3$ & Serra-Kiel collection. Department of Earth and Ocean Dynamics, University of Barcelona (UB) \\
\hline $\mathrm{Cm} 4$ & Serra-Kiel collection. Department of Earth and Ocean Dynamics, University of Barcelona (UB) \\
\hline $\mathrm{Cm} 5$ & Serra-Kiel collection. Department of Earth and Ocean Dynamics, University of Barcelona (UB) \\
\hline $\mathrm{Cm} 6$ & Serra-Kiel collection. Department of Earth and Ocean Dynamics, University of Barcelona (UB) \\
\hline $\mathrm{Cm} 7$ & Serra-Kiel collection. Department of Earth and Ocean Dynamics, University of Barcelona (UB) \\
\hline $\mathrm{Cm} 8$ & Serra-Kiel collection. Department of Earth and Ocean Dynamics, University of Barcelona (UB) \\
\hline Coll 3 & Serra-Kiel collection. Department of Earth and Ocean Dynamics, University of Barcelona (UB) \\
\hline Dor M'Said & Serra-Kiel collection. Department of Earth and Ocean Dynamics, University of Barcelona (UB) \\
\hline Er 1 & Serra-Kiel collection. Department of Earth and Ocean Dynamics, University of Barcelona (UB) \\
\hline Er 5 & Serra-Kiel collection. Department of Earth and Ocean Dynamics, University of Barcelona (UB) \\
\hline Eu 2 & Instituto Geológico y Minero de España (IGME) \\
\hline G 3 & Instituto Geológico y Minero de España (IGME) \\
\hline K 1 & Serra-Kiel collection. Department of Earth and Ocean Dynamics, University of Barcelona (UB) \\
\hline K 2 & Serra-Kiel collection. Department of Earth and Ocean Dynamics, University of Barcelona (UB) \\
\hline $\mathrm{L} 12$ & Department of Stratigraphy and Paleontology, University of the Basque Country (UPV/EHU) \\
\hline $\mathrm{L} 13$ & Department of Stratigraphy and Paleontology, University of the Basque Country (UPV/EHU) \\
\hline L 14 & Department of Stratigraphy and Paleontology, University of the Basque Country (UPV/EHU) \\
\hline $\mathrm{L} 15$ & Department of Stratigraphy and Paleontology, University of the Basque Country (UPV/EHU) \\
\hline $\mathrm{L} 17$ & Department of Stratigraphy and Paleontology, University of the Basque Country (UPV/EHU) \\
\hline L 18 & Department of Stratigraphy and Paleontology, University of the Basque Country (UPV/EHU) \\
\hline $\mathrm{L} 19$ & Department of Stratigraphy and Paleontology, University of the Basque Country (UPV/EHU) \\
\hline $\mathrm{L} 20$ & Serra-Kiel collection. Department of Earth and Ocean Dynamics, University of Barcelona (UB) \\
\hline L 21 & Department of Stratigraphy and Paleontology, University of the Basque Country (UPV/EHU) \\
\hline $\mathrm{L} 22$ & Department of Stratigraphy and Paleontology, University of the Basque Country (UPV/EHU) \\
\hline $\mathrm{L} 24$ & Department of Stratigraphy and Paleontology, University of the Basque Country (UPV/EHU) \\
\hline L 25 & Department of Stratigraphy and Paleontology, University of the Basque Country (UPV/EHU) \\
\hline $\mathrm{L} 26$ & Department of Stratigraphy and Paleontology, University of the Basque Country (UPV/EHU) \\
\hline L 27 & Department of Stratigraphy and Paleontology, University of the Basque Country (UPV/EHU) \\
\hline L 3 & Department of Stratigraphy and Paleontology, University of the Basque Country (UPV/EHU) \\
\hline$\overline{L L} 4$ & Department of Stratigraphy and Paleontology, University of the Basque Country (UPV/EHU) \\
\hline L5 & Department of Stratigraphy and Paleontology, University of the Basque Country (UPV/EHU) \\
\hline Le 2 & Department of Stratigraphy and Paleontology, University of the Basque Country (UPV/EHU) \\
\hline
\end{tabular}


TABLE V. Continued.

\begin{tabular}{|c|c|}
\hline Sample & Repository \\
\hline Le 5 & Department of Stratigraphy and Paleontology, University of the Basque Country (UPV/EHU) \\
\hline Le 7 & Department of Stratigraphy and Paleontology, University of the Basque Country (UPV/EHU) \\
\hline Le 8 & Serra-Kiel collection. Department of Earth and Ocean Dynamics, University of Barcelona (UB) \\
\hline Le Quillet (Petites Pyrénées) & Serra-Kiel collection. Department of Earth and Ocean Dynamics, University of Barcelona (UB) \\
\hline Narp (Petites Pyrénées) & Serra-Kiel collection. Department of Earth and Ocean Dynamics, University of Barcelona (UB) \\
\hline Orio 3 & Department of Stratigraphy and Paleontology, University of the Basque Country (UPV/EHU) \\
\hline RM-Le 12 & Instituto Geológico y Minero de España (IGME) \\
\hline $\begin{array}{l}\text { Ruisseau de la Mède (Petites } \\
\text { Pyrénées) }\end{array}$ & Serra-Kiel collection. Department of Earth and Ocean Dynamics, University of Barcelona (UB) \\
\hline Salt Range (Pakistan) & Serra-Kiel collection. Department of Earth and Ocean Dynamics, University of Barcelona (UB) \\
\hline Salv 4 & Instituto Geológico y Minero de España (IGME) \\
\hline Salv 5 & Instituto Geológico y Minero de España (IGME) \\
\hline Tap 10 & Instituto Geológico y Minero de España (IGME) \\
\hline Tap 15 & Serra-Kiel collection. Department of Earth and Ocean Dynamics, University of Barcelona (UB) \\
\hline Te 1 & Serra-Kiel collection. Department of Earth and Ocean Dynamics, University of Barcelona (UB) \\
\hline Te 4 & Serra-Kiel collection. Department of Earth and Ocean Dynamics, University of Barcelona (UB) \\
\hline Ur 10 & Department of Stratigraphy and Paleontology, University of the Basque Country (UPV/EHU) \\
\hline Ur 15 & Department of Stratigraphy and Paleontology, University of the Basque Country (UPV/EHU) \\
\hline Ur 17 & Department of Stratigraphy and Paleontology, University of the Basque Country (UPV/EHU) \\
\hline Ur 18 & Serra-Kiel collection. Department of Earth and Ocean Dynamics, University of Barcelona (UB) \\
\hline Ur 3 & Department of Stratigraphy and Paleontology, University of the Basque Country (UPV/EHU) \\
\hline Ur 4 & Department of Stratigraphy and Paleontology, University of the Basque Country (UPV/EHU) \\
\hline Ur 6 & Department of Stratigraphy and Paleontology, University of the Basque Country (UPV/EHU) \\
\hline Ur 8 & Department of Stratigraphy and Paleontology, University of the Basque Country (UPV/EHU) \\
\hline Ur 9 & Department of Stratigraphy and Paleontology, University of the Basque Country (UPV/EHU) \\
\hline Urb 1 & Department of Stratigraphy and Paleontology, University of the Basque Country (UPV/EHU) \\
\hline Urb 12 & Department of Stratigraphy and Paleontology, University of the Basque Country (UPV/EHU) \\
\hline Urb 13 & Department of Stratigraphy and Paleontology, University of the Basque Country (UPV/EHU) \\
\hline Urb 15 & Department of Stratigraphy and Paleontology, University of the Basque Country (UPV/EHU) \\
\hline Urb 18 & Department of Stratigraphy and Paleontology, University of the Basque Country (UPV/EHU) \\
\hline Urb 19 & Department of Stratigraphy and Paleontology, University of the Basque Country (UPV/EHU) \\
\hline Urb 20 & Department of Stratigraphy and Paleontology, University of the Basque Country (UPV/EHU) \\
\hline Urb 25 & Department of Stratigraphy and Paleontology, University of the Basque Country (UPV/EHU) \\
\hline Urb 26 & Department of Stratigraphy and Paleontology, University of the Basque Country (UPV/EHU) \\
\hline Urb 27 & Department of Stratigraphy and Paleontology, University of the Basque Country (UPV/EHU) \\
\hline Urb 31 & Department of Stratigraphy and Paleontology, University of the Basque Country (UPV/EHU) \\
\hline Urb 4 & Department of Stratigraphy and Paleontology, University of the Basque Country (UPV/EHU) \\
\hline Urrob 1 & Instituto Geológico y Minero de España (IGME) \\
\hline Urrob 3 & Instituto Geológico y Minero de España (IGME) \\
\hline
\end{tabular}

